Historic, Archive Document

Do not assume content reflects current scientific knowledge, policies, or practices. 
. 


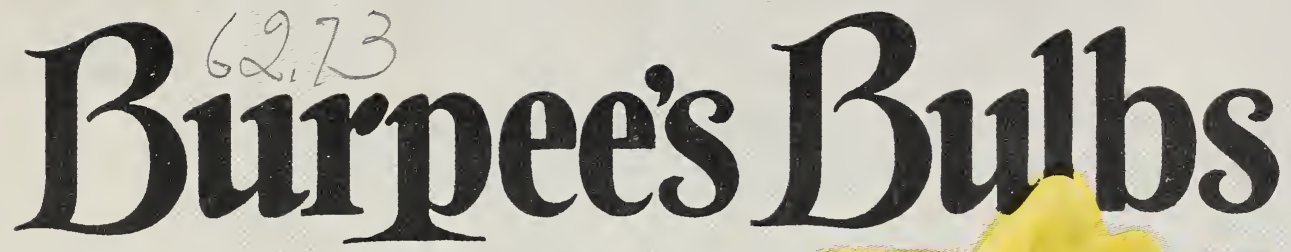

\section{FOR FALL PLANTING} 1927

Loveliness 


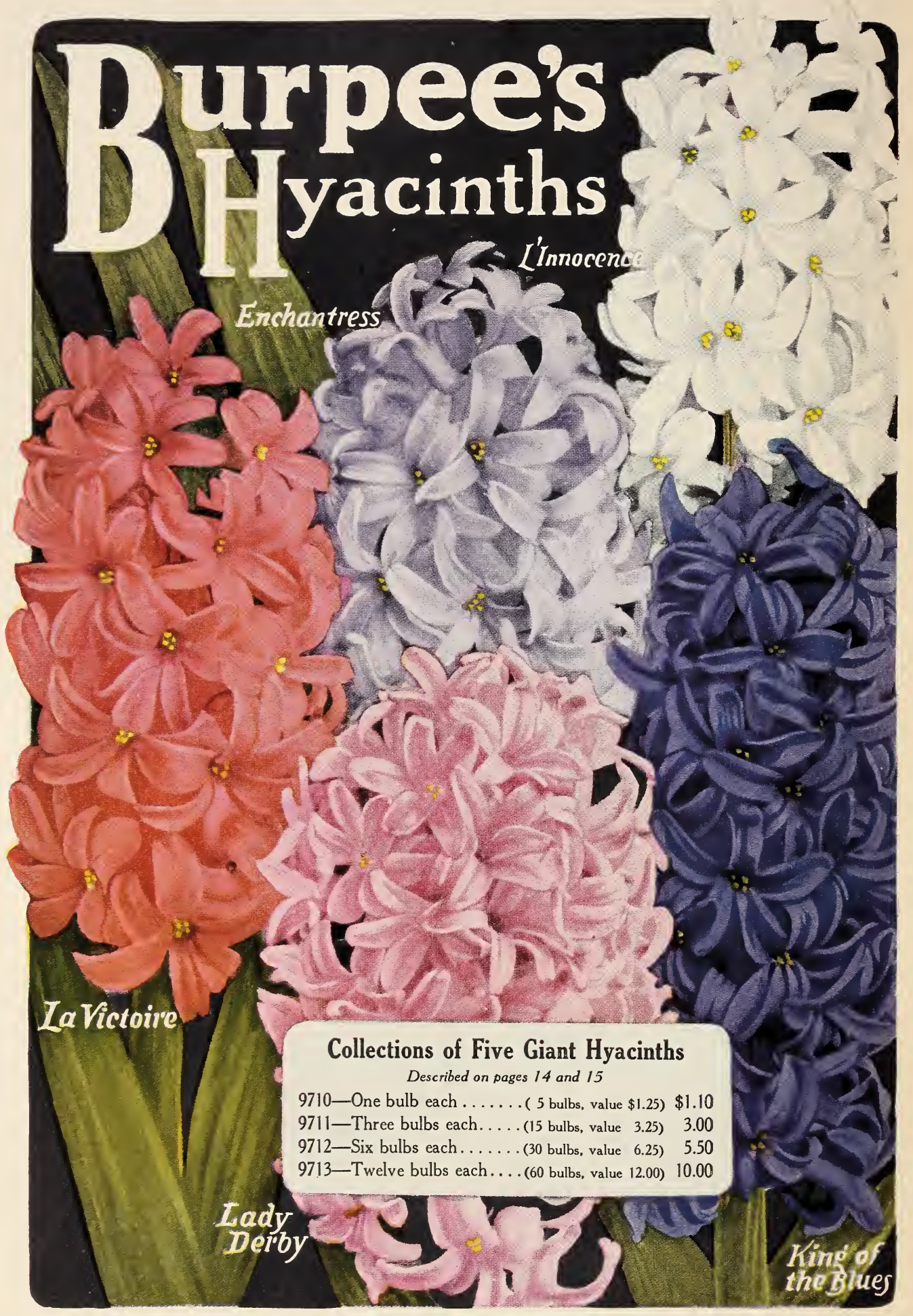

Copyright, 1927, by W. Atlee Burpee Co., Philadelphia, Pa. U. S. A. 


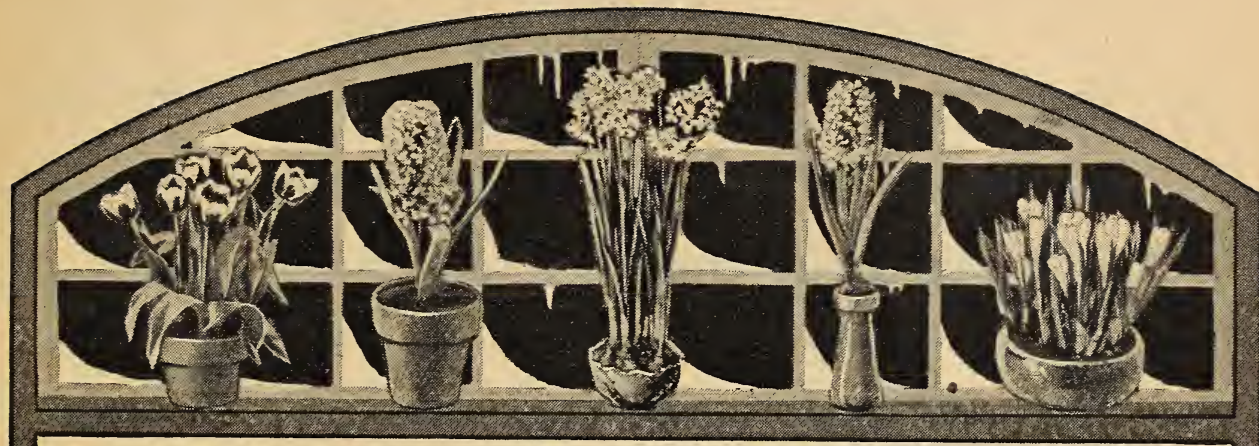

\section{To Flower Lovers:}

7 ULIPS are lower in price this fall than they have been for many years and now is your opportunity to start a gay and 1 showy display that will be a delight for years to come. The new crop of Tulips is exceptionally good and we are glad to pass on to you a substantial saving for first-class guaranteed bulbs.

You will find all prices in this catalog very reasonable and we urge you to plant generously this fall.

At little cost you can enjoy a display in your spring garden-an array of colors that in brilliancy and glory will defy the brush of the very best masters of the canvas.

While winter rages and storms outside, you can enjoy their exquisite fragrance and feast your eyes on their glorious colors. But to enjoy them you must plant now for winter blooming in the house.

Flowers!- How much they mean to us, to our friends, to those for whom we care, or perhaps to the stranger who, passing along the wayside, catches a glimpse of their spirit and beauty.

Pleasure and happiness that cannot be measured in moneyvalues are awaiting us, but we must act-we must plant NOW.

We are waiting to serve you.

Faithfully yours,

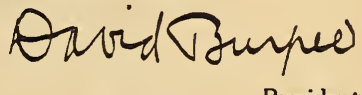

The illustration below shows our

Gold Medal Exhibit of Bulbs at the Philadelphia Flower Show, March, 1927.

President

w. Atree Bumper fr.

Secretary-Treasurer

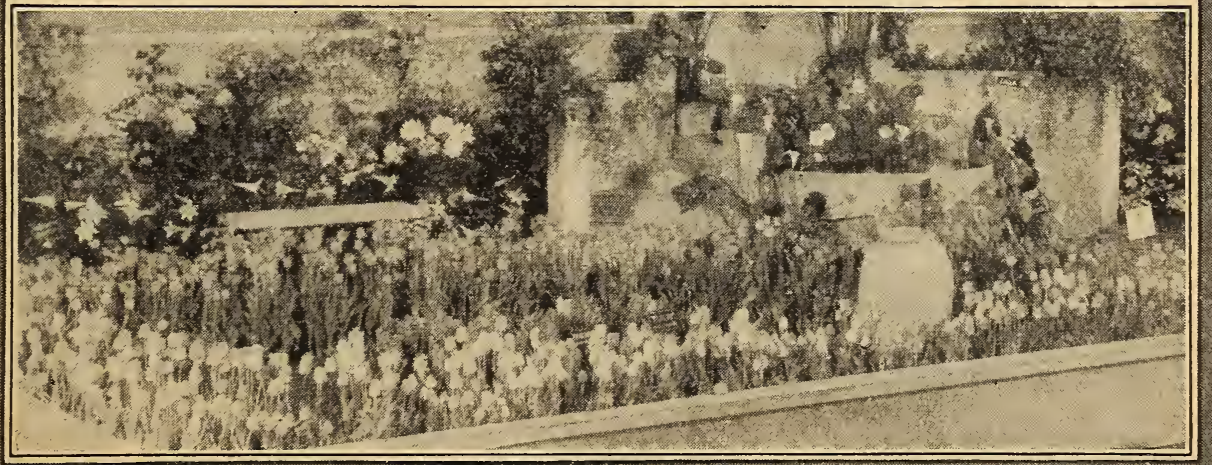




\title{
NOW IS THE TIME
}

\section{To Order Your Spring-Flowering Bulbs -The Bulbs to Plant in the Fall-}

Order your Dutch Bulbs now because they must be planted soon if you want a good display in your early spring garden. It is safe, quick, and convenient to buy your bulbs by mail, and it is wise economy to purchase from such a reliable source as Burpee in Philadelphia-the Largest Mail Order Seed House in the World. We have prepared special Cultural Leaflets which will show you how easy it is to grow good flowers from Bulbs. They will be sent FREE with your order. Ask for them by number.

\author{
No. 20 How to Establish a Lawn \\ No. 30 Roots and Bulbs for Fall Planting \\ No. 31 Bulbs for Winter and Spring Blooming \\ No. 32 How to Grow Peonies
}

How to Order Please be areful to sign your full name and Always write plainly and be sure to give correct variety numbers.

Our reputation as honest and reliable seedsmen can be learned from any bank or trust company, or from your neighbors. Remit with your order, Post Office Money Order, Express Order, Check, or Draft. If you send Cash or Stamps register your letter.

The liberal Burpee Guarantee should convince you fully of our confidence in the superiority of Burpee's Bulbs and Seeds. And remember, the value of a guarantee is not in what is said but who says it. Our Guarantee We guarantee the vitality and purity of our the purchase price, and we guarantee the safe arrival of all goods. You can have your money back any time within the year if you are not satisfied with the results from Burpee's bulbs, roots, or seeds.

But even with Burpee Quality Bulbs and Seeds, success in gardening depends largely upon cultivation, soil, and weather conditions. It is therefore agreed that in no case shall W. Atlee Burpee Co. be liable for more than the amount actually paid for the bulbs and seeds.

This is the guarantee that protects all who purchase from Burpee in Philadelphia.

Burpee's Bulbs are sure to bloom and will give complete satisfaction. When you purchase Burpee's Bulbs you are assured of clean healthy stock that has been properly cured to preserve the life and vigor of the dormant bulb. Buy the best bulbs procurable-they are the cheapest in the end.

\section{BULBS AND SEEDS DELIVERED FREE}

AII bulbs and seeds offered in this catalog will be delivered free anywhere in the United States and its possessions, except where stated otherwise. We will send them to you by Parcel Post or Express Prepaid, whichever way seems best to us. To our Canadian and foreign customers we prepay the forwarding charges, but the customer pays custom charges upon delivery. 


\section{DARWIN TULIPS}

Outdoors: The Darwin Tulips come into bloom after the Early Single varieties have finished flowering. They are stronger in growth, a few inches taller, and the flowers are considerably larger. The Tulip lover should plant large

quantities of this type to continue the display after the Early Single Tulips have passed their prime. Darwin Tulips are easily grown and they look well if planted in formal beds, or grouped irregularly among shrubbery or perennials.

In the House: For forcing indoors, the Darwin Tulips are unsurpassed. They bloom shortly after the Early Single varieties, and their fine range of good colors greatly adds to the number of colors that can be had at that season of the year. Planted in pots, they will bloom for nearly two weeks.

9153 Afterglow A Iate flowering Darwin Tulip with beautiful bright rosy orange flowers, shaded salmon at the edges. The inside of the petals is rich orange; 26 inches tall. 6 for $60 \notin ; 12$ for $\$ 1.15 ; 50$ for $\$ 4.35 ; 100$ for $\$ 8.50$.

9150 Baron de la Tonnaye See illustration. Bright rose margined with delicate blush-rose. It is an excellent forcing variety and also fine for outdoors. Baron de la Tonnaye is a very popular variety, of strong growth, bearing magnificent flowers which are held upright on long substantial stems. Of stately growth; 28 inches tall. 6 for $30 \notin ; 12$ for $55 \dot{\xi} ; 0$ for $\$ 1.95 ; 100$ for $\$ 3.75$.

9155 Bleu Aimable A most charming Darwin Tulip. Bright violet-purple with a cast of clear steel blue. The inside of the petals is dark violet-purple showing a distinct blue base. 6 for $35 \phi ; 12$ for $60 \phi ; 50$ for $\$ 2.10 ; 100$ for $\$ 4.00$.

9154 Clara Butt See illustration. The Iarge flowers are well rounded and are clear bright pink tinted with salmon-rose. The petals show a deep blue base on the inside. Clara Butt is an excellent bedding variety because of its strong and sturdy habit; 23 inches tall. 6 for $30 k$; 12 for 50 ; 50 for $\$ 1.85$; 100 for $\$ 3.50$.

9158 Centenaire An early blooming variety with rich violetrose blooms and a large blue base. Easily forced and wonderful for the garden. Large flowers carried on stems 30 inches tall. 6 for $35 \phi ; 12$ for $65 \phi ; 50$ for $\$ 2.35 ; 100$ for $\$ 4.50$.

9156 Dream Bright Heliotrope with a deep violet hue on the inside. The base is distinctly marked with bright blue. The flowers are large and well formed; 22 inches tall. 6 for $35 k ; 12$ for $65 \xi ; 50$ for $\$ 2.35 ; 100$ for $\$ 4.50$.

9157 Euterpe This bright lilac variety is an outstanding color among the Darwin Tulips. It is a color which combines well with all other shades of this class. Large flowers of excellent form; 21 inches tall. 6 for 35 $\phi ; 12$ for $65 c ; 50$ for $\$ 2.35 ; 100$ for $\$ 4.50$.

9159 Flamingo The flowers are large and well formed, with petals of substantial texture. The color of the blooms is a most pleasing and Iuminous shade of shell-pink; 22 inches tall. 6 for $35 \phi ; 12$ for $65 \phi ; 50$ for $\$ 2.35 ; 100$ for $\$ 4.50$.

\section{Tulip Garden Collection}

\section{Tulip Bulbs for only $\$ 3.50$, delivered}

If you do not mind leaving the selection of the varieties to us, you can purchase this Tulip Collection at a bargain price. There is a place in almost every garden where a hundred Tulip Bulbs of various types will frt well. We will send you

100 bulbs, named varieties, of our own selection, for $\$ 3.50$

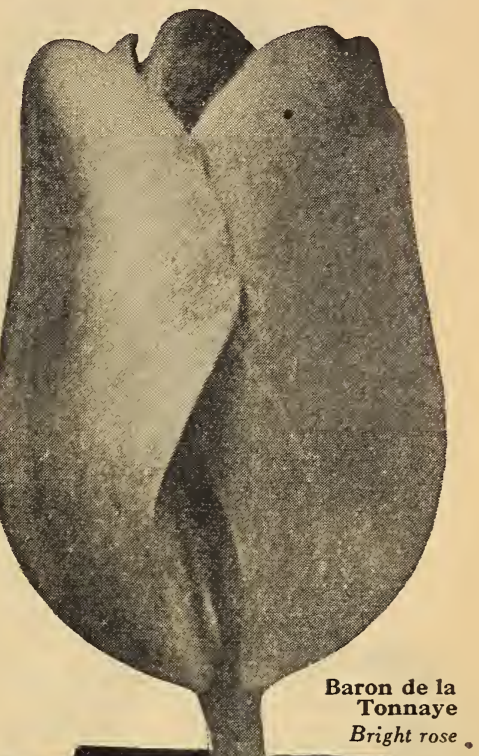


One thousand bulbs of a variety will be supplied at nine times the 100 price

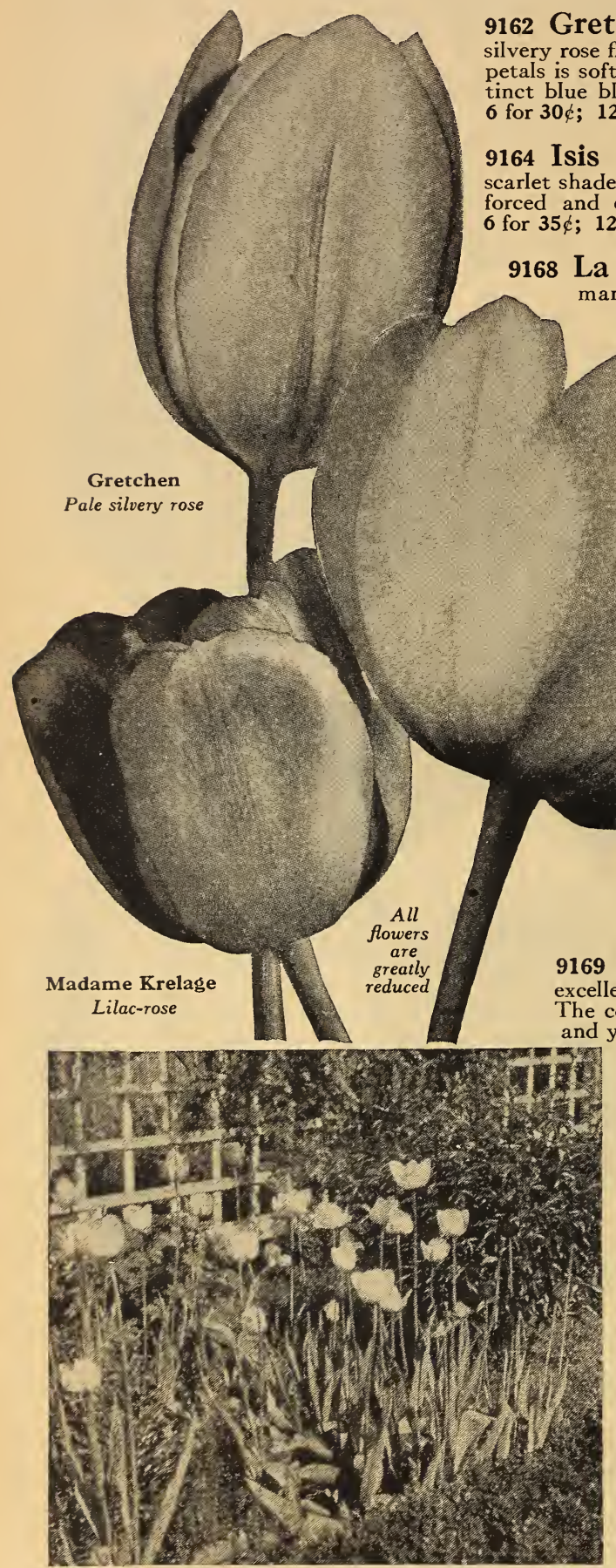

Darwin Tulips make a charming border
9172 Farncombe Sanders The petals are fiery rose-scarlet on the outside. The inside is vivid cherryscarlet, showing a blue base and shading into white at the very end. A bold and impressive flower; 27 inches tall. 6 for $30 \dot{\phi} ; 12$ for $55 \dot{k} ; 50$ for $\$ 1.95 ; 100$ for $\$ 3.75$.

9162 Gretchen (Margaret). See illustration. Pale silvery rose flushed with silvery white. The inside of the petals is soft pink shaded with white and showing a disinct blue blotch near the base. Grows 23 inches tall. ; 12 for $55 \dot{\phi} ; 50$ for $\$ 1.95 ; 100$ for $\$ 3.75$

is Magnificent flowers of a rich fiery crimsonand excellent for the garden; 26 inches tall.

9168 La Tulip Noire A quaint dark velvety maroon color, so dark that it appears nearly black. This is not merely a curiosity -it is a flower of fine size and good form. It adds color contrast to any planting; 24 inches tall. 6 for $40 \phi$; 12 for $75 \phi ; 50$ for $\$ 2.85$; 100 for $\$ 5.50$.

\section{$9165 \mathrm{~K}$ ing} Harold Deep rich crimson-red with a sharply contrasting white base. The combi$n$ ation is most artistic and impressive. One of the most vigorous of all Darwin Tulips, with massive, well-formed flowers borne on long stems; 24 Loveliness inches tall. It is a sure bloomer. 6 for $35 \xi$; 12 for $65 \xi$; 50 for $\$ 2.35 ; 100$ for $\$ 4.50$.

9169 Loveliness See illustration. This is an excellent variety, with flowers of very good size. The color is a lovely soft carmine-rose. A warm and yet brilliant shade with a great appeal. The plants are strong and carry the blooms on long heavy stems. A planting of this variety is a truly magnificent sight. 6 for $35 \dot{\phi}$; 12 for $65 \dot{k} ; 50$ for $\$ 2.35 ; 100$ for $\$ 4.50$.

9173 Nauticas This is a beautiful variety, with immense flowers of rich carmine-rose with a bright silky sheen. The base shows a distinct dark violet tint with an attractive bronze tinge overlying it. The blooms are not only large but they are well rounded and of substantial texture. Most attractive if planted with white, yellow, or dark red shades; 26 inches tall. 6 for $35 \nLeftarrow ; 12$ for $65 \xi ; 50$ for $\$ 2.35 ; 100$ for $\$ 4.50$.

9170 Madame Krelage See illustration. The graceful flowers are bright lilac-rose shading to silvery rose on the edge of the petals. The inside of the flower is deep rose-pink. Plant it in large beds or use it clumped among the shrubbery or in the perennial bed to get the best effect. The even height of the plants adds to the display; 27 inches tall. 6 for $30 k$; 12 for $55 \notin ; 50$ for $\$ 1.95 ; 100$ for $\$ 3.75$. 
9181 Professor Rauwenhof The petals are bright cherry-red with a glistening scarlet suffusion on the inside. Sharply contrasting with this color is the ivory-white base marked with a bright blue star. Professor Rauwenhof is a decidedly popular Darwin Tulip as its color is distinctive and showy. Its richness of color and massive appearance make it suited for both garden display and forcing indoors. The flowers are large, of very good form, and composed of heavy petals. Grows 28 inches tall. 6 for $35 \dot{\alpha}$; 12 for 60 ; 50 for $\$ 2.10$; 100 for $\$ 4.00$.

9174 Pride of Haarlem They are most beautiful in the border or among shrubbery. Bright rosy carmine with a blue base. It is a cheerful and charming color, which goes well with the bold, massive flowers. The tallstemmed flowers are agreeably sweet scented; 27 inches tall. 6 for $30 \xi ; 12$ for $55 \xi ; 50$ for $\$ 1.95 ; 100$ for $\$ 3.75$.

9184 Rev. Ewbank See illustration. A delicate combination of Iavender-violet flushed with dove-gray, which deepens somewhat toward the lower part of the petals and is relieved by the contrasting white base. This combination represents a most desirable shade. The blooms are large, of exquisite form, and very artistic appeal. A strong sturdy grower of uniformly large size; 24 inches tall. 6 for $35 \dot{\xi} ; 12$ for $60 \dot{\xi} ; 50$ for $\$ 2.20 ; 100$ for $\$ 4.25$.

9190 William Pitt Very dark crimson with a purplish sheen on the outside of the petals. The base is white, starred with blue. A large and graceful flower carried on a heavy stem; 26 inches tall. 6 for $40 \xi ; 12$ for 70 ; 50 for $\$ 2.60 ; 100$ for $\$ 5.00$.

9189 White Queen (La Candeur) See illustration. Upon opening, the flowers show a slight tinge of rose, but when fully expanded they are practically white. White Queen is fine for outdoors or for winter and spring flowering indoors; 30 inches tall. 6 for 40 ; 12 for $70 \notin ; 50$ for $\$ 2.60 ; 100$ for $\$ 5.00$.

9192 Zulu Rich velvety purpleblack flowers with a brilliant purple edge. The blooms are large, egg shaped, and are fine for forcing or the garden. Height, 27 inches. 6 for 40 ; 12 for 75 ; 50 for $\$ 2.85 ; 100$ for $\$ 5.50$.

\section{Darwin Tulips Mixed} Our mixture contains a wide range of colors. Many gardeners love variety of color, particularly in the spring garden, and we offer a mixture of Darwin Tulips which will make a fine showing. 6 for 30 ; 12 for 50 ; 50 for $\$ 1.70$; 100 for $\$ 3.25 ; 500$ for $\$ 15.50 ; 1000$ for $\$ 30.00$.

\section{Collections of Six Darwin Tulips}

These collections contain the following: Clara Butt, La Tulip Noire, Madame Krelage, Prof essor Rauwenhof, Rev. Ewbank, and

White Queen. They will be sent to you prepaid.

9753 - 3 each ( 18 bulbs, value $\$ 1.16$ ), $\$ 0.95$

$9754-6$ each ( 36 bulbs, value 2.10 ), 1.65

9755-12 each ( 72 bulbs, value 3.70 ), 3.00

9756-25 each (150 bulbs, value 7.00 ), $\quad \mathbf{5 . 7 5}$
9176 Princess Juliana Artistic flowers of immense size. The color is an intense scorching orange-scarlet relieved by a white base. The shades which make the most brilliant display usually sell the best, and Princess Juliana is one of the very brightest Darwin Tulips in existence. The richness of color is particularly effective if planted in masses or naturalized in large clumps among shrubbery or the perennial border. A stately variety, growing 26 inches tall. 6 for 40 ; 12 for $75 \dot{0}$; 50 for $\$ 2.85 ; 100$ for $\$ 5.50$.

9175 Prince of the Netherlands Bright fiery scarlet flushed with rich salmon-rose. This combination is enlivened by a showy white mid-rib which runs from the blue base to the tips of the petals; 27 inches tall. 6 for $45 \xi ; 12$ for 85 ; 50 for $\$ 3.10 ; 100$ for $\$ 6.00$. 


\section{BREEDER TULIPS}

Of all Tulips the Breeders are without question the most striking. With their tall majestic growth and truly enormous blooms, they are rivals to the finest of the Darwins. But it is their rich coloring which places them in a class by themselves-old gold and bronze, crushed strawberry and purple, terra-cotta and salmon, and other rare combinations of odd shades are represented.

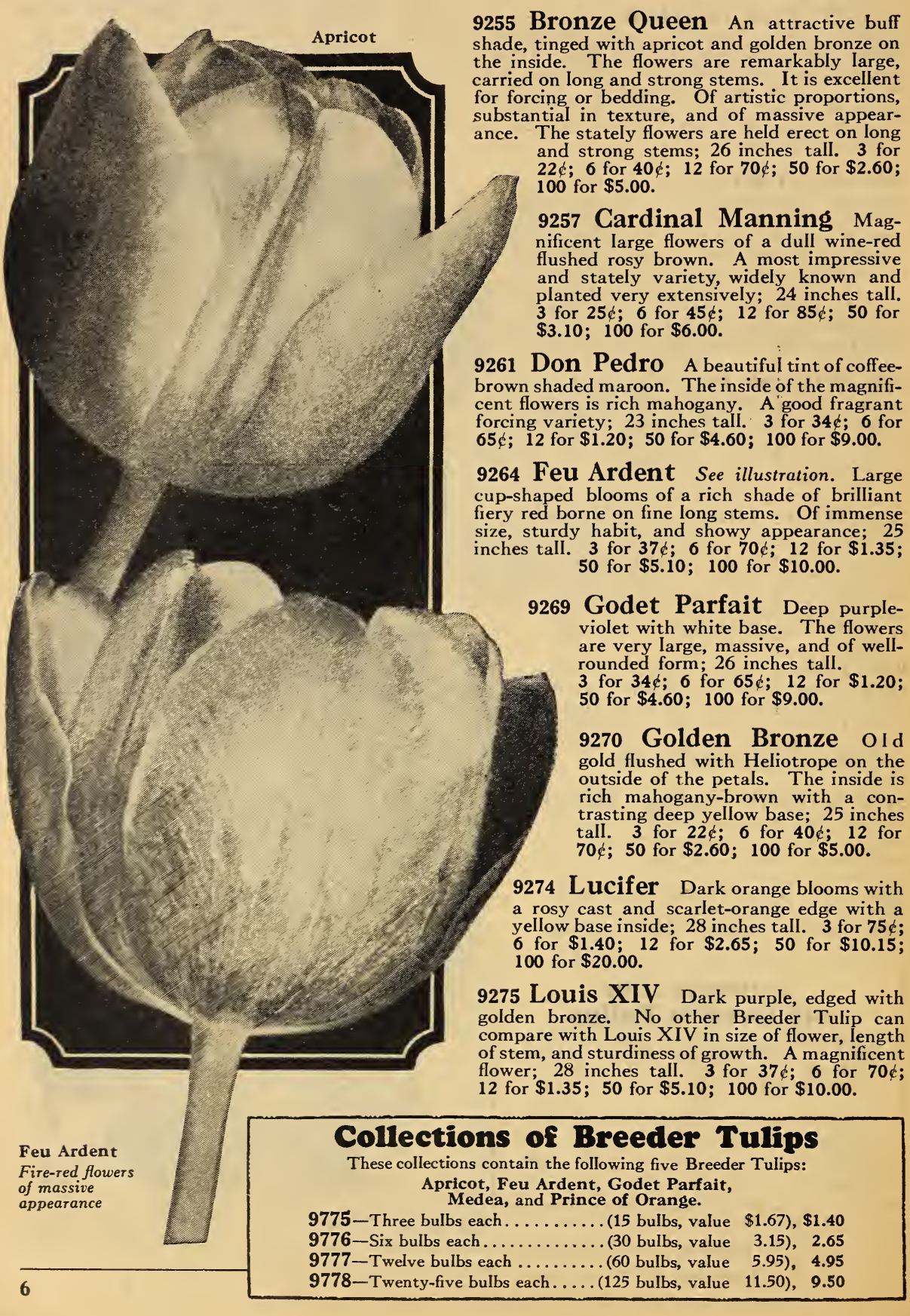

9252 Apricot See illustration. Ruddy apricot edged with a bronzy buff seam. The base of the petals is yellow, shading into an olive halo. A magnificent flower of a quaint and artistic color combination. Those who like the unusual will include this showy and free-blooming variety

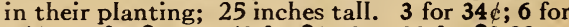
$65 \dot{0} ; 12$ for $\$ 1.20$; 50 for $\$ 4.60$; 100 for $\$ 9.00$. carried on long and strong stems. It is excellent for forcing or bedding. Of artistic proportions, and strong stems; 26 inches tall. 3 for $22 \phi ; 6$ for $40 \xi ; 12$ for $70 \notin ; 50$ for $\$ 2.60$ 0 for $\$ 5.00$. and stately variety, widely known and planted very extensively; 24 inches tall. 3 for $25 \phi ; 6$ for $45 \phi ; 12$ for $85 \phi ; 50$ for $\$ 3.10 ; 100$ for $\$ 6.00$.

coffeethe magnififorcing variety. 23 inches tall. 3 for $346^{\circ} 6$ for ; 12 for $\$ 1.20 ; 50$ for $\$ 4.60 ; 100$ for $\$ 9.00$.

See illustration. Large size, sturdy habit, and showy appearance; 25 50 for $\$ 5.10 ; 100$ for $\$ 10.00$.

purpleviolet with white base. The flowers .

for $34 \phi ; 6$ for $65 \notin ; 12$ for $\$ 1.20$; 25 inches tall. 3 for 22 ; 6 for 40 ; 12 for ; 50 for $\$ 2.60$; 100 for $\$ 5.00$.

9274 Lucifer Dark orange blooms with rosy cast and scarlet-orange edge with a for $\$ 1.40$; 12 for $\$ 2.65 ; 50$ for $\$ 10.15$; 00 for $\$ 20.00$.

9275 Louis XIV Dark purple, edged with (1) Dark purple, edged with compare with Louis XIV in size of flower, length fower; 28 inches tall. 3 for $37 \dot{\alpha}$; 6 for $70 k$; 2 for $\$ 1.35 ; 50$ for $\$ 5.10 ; 100$ for $\$ 10.00$. substantial in texture, and of massive appearstem, and sturdiness of growth. A magnificent 
9278 "Madame Lethierry Rich dark cherry-rose, attractively edged and flushed with bright salmon. As a cut-flower it lasts for many days and its cheerful bright color makes it always welcome for home decoration. Madame Lethierry is one of the best known Breeder Tulips and always gives entire satisfaction. The flowers are of magnificent size, heavy substance, and artistic form; 27 inches tall. 3 for $32 \phi ; 6$ for 60 \&; 12 for $\$ 1.10 ; 50$ for $\$ 4.10 ; 100$ for $\$ 8.00$.

9280 Medea This beautiful variety represents a shade which is very difficult to describe - crushed strawberry shaded with bright Heliotrope and having a distinct yellow center. It is a quaint and artistic flower of unusual appeal and can be highly recommended for either forcing or bedding. The immense flowers are carried on fine long stems. They are of excellent form and heavy texture; 17 inches tall. 3 for $25 \phi ; 6$ for $45 \& ; 12$ for 85 ; ; 50 for $\$ 3.10$; 100 for $\$ 6.00$.

\section{Old Times A grand}

flower of long, pointed form.

It is an unusual color-garnet, edged Primrose-yellow and touched with green near the base. The combination of these shades gives an odd and quaint flower; 24 inches tall. 3 for $29 k ; 6$ for $55 k$; 12 for $\$ 1.00 ; 50$ for $\$ 3.85 ; 100$ for $\$ 7.50$.

9286 Panorama The color is rich orange attractively shaded with bright mahogany. The contrasting margin is most attractive; 26 inches tall. 3 for $25 \phi ; 6$ for $45 \phi ; 12$ for $80 \phi ;$ 50 for $\$ 2.95 ; 100$ for $\$ 5.75$.

9287 Plutarchus Terra-cotta-bronze shaded with pastel litac. The inside is a shade brighter. A handsome flower borne on a fine long and strong stem; 26 inches tall. 3 for 27 ; 6 for $50 \notin ; 12$ for $95 \xi ; 50$ for $\$ 3.60 ; 100$ for $\$ 7.00$.

9290 Turenne A beautiful variety, with large wellformed blooms. The flowers are purplish brown with a broad margin of bright amber-yellow and a yellow base. A decidedly quaint yet most artistic color combination; 28 inches tall. 3 for $37 \xi ; 6$ for $70 \notin ; 12$ for $\$ 1.35 ; 50$ for $\$ 5.10 ; 100$ for $\$ 10.00$.

9294 Velvet King This is a grand Breeder Tulip with dark glossy purple-maroon flowers, marked with yellow and blue at the base of the petals. A strong vigorous grower with blooms of enormous size, carried on fine strong stems. Grows to a height of 25 inches. 3 for $37 \xi$; 6 for $70 \phi ; 12$ for $\$ 1.35 ; 50$ for $\$ 5.10 ; 100$ for $\$ 10.00$.

9293 Vulcain Reddish apricot with a broad margin of bright buffyellow. The inside of the petals is rich deep apricot edged yellow. The base is green; 25 inches tall. 3 for $45 \phi ; 6$ for 80 ; 12 for $\$ 1.55$; 50 for $\$ 5.85 ; 100$ for $\$ 11.50$.

9297 Breeder Tulips Mixed This mixture contains, in addition to the varieties listed and described on these pages, quite a number of other distinct and beautiful varieties which add to the brilliant and colorful effect of the mixture. They are very showy among perennials and in front of shrubbery. 6 for $35 \phi ; 12$ for $60 \phi ; 50$ for $\$ 2.15$; 100 for $\$ 4.15 ; 500$ for $\$ 19.50$; 1000 for $\$ 37.50$.

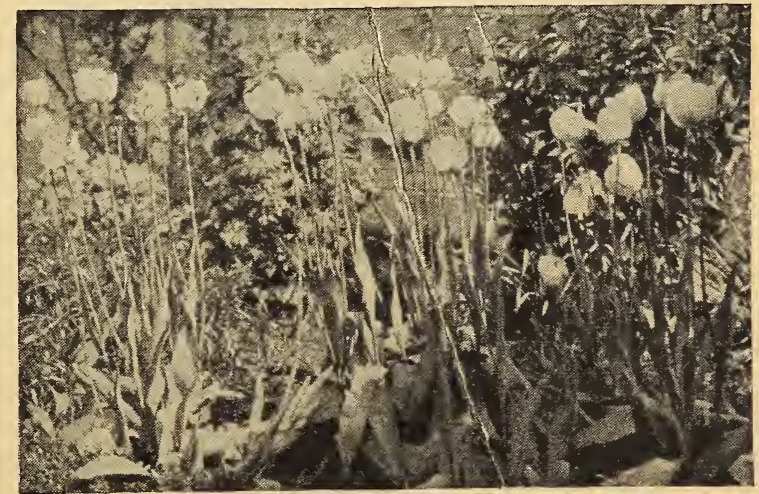

The stately Breeder Tulips make an attractive showing 


\section{COTTAGE TULIPS}

The May flowering or Cottage Tulips resemble in general habit and growth the Darwins. They also bloom at the same time. This is an advantage because it permits the planting of both types together in a bed and having the varieties in bloom all at the same time. As bedders, to be planted either alone or in clumps placed in the foreground of shrubbery or in the perennial bed, they are unsurpassed. They are also planted extensively for winter blooming because they are easily forced and grow very large.

9205 Carnation This is the Old-English picotee with snow-white blooms, changing to carmine-rose as they open. A wonderful flower of excellent size, carried on fine long stems. A very showy flower. 6 for $35 \notin$; 12 for 60 c; 50 for $\$ 2.10 ; 100$ for $\$ 4.00$.

9206 Fairy Queen Soft rosy lilac flowers with a margin of bright amber yellow. The combination of colors isquaint and artistic. The blooms are of large size and very good form. They are carried upright on strong stems. Fairy Queen is a lovely garden variety of excellent and stately habit; 20 inches tall. 6 for $35 \dot{\alpha}$; 12 for $60 \dot{c} ; 50$ for $\$ 2.10 ; 100$ for $\$ 4.00$.

9210 Gesneriana Major This is a lovely variety with rich crimson-scarlet flowers having a brilliant blue base. The flowers are made up of long narrow petals. A very effective garden variety and excellent for cutting; 23 inches tall. 6 for $35 \dot{c} ; 12$ for $60 \dot{\xi} ; 50$ for $\$ 2.10 ; 100$ for $\$ 4.00$.

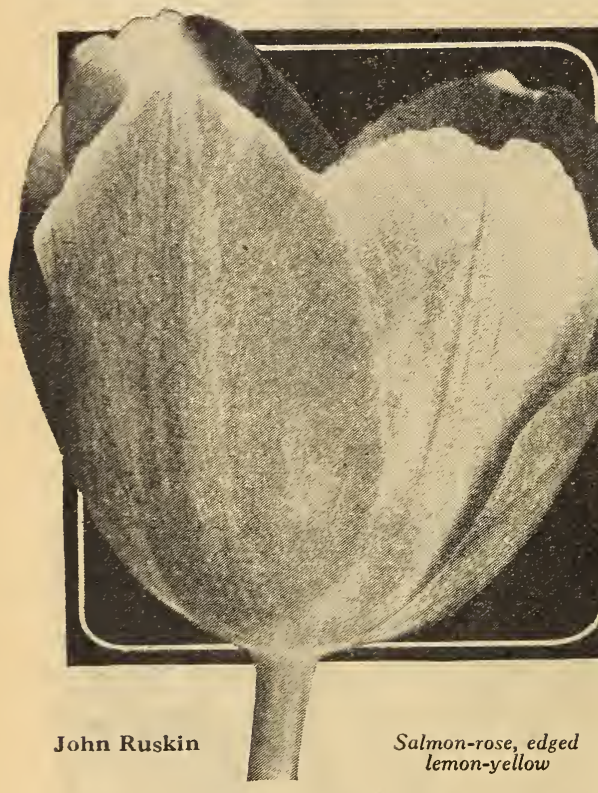

9216 John Ruskin See illustration. Mammoth flowers carried on strong stems. The color of the flowers is a beautiful blend of salmon-rose edged with soft lemon-yellow. The inside of the petals is a rich lilac shaded rose with a broad margin of yellow on the inside and a touch of yellow at the base. It is a beautiful variety and a strong grower; 16 inches tall. 6 for $40 \dot{\phi}$; 12 for $70 ; 50$ for $\$ 2.60 ; 100$ for $\$ 5.00$.
9214 Inglescomb Pink This lovely Cottage Tulip is one of the most popular of all Giant Tulips because of its attractive color and excellent habit. The flowers are a pleasing soft rosy pink. When they begin to open they show a tinge of salmon evenly cast over the whole flower, but as the flowers age they turn to a pure rose shade. The flowers are large and nearly round. Excellent for borders and easily forced. A stately plant, growing 20 inches tall. 6 for $30 \notin ; 12$ for $55 \dot{\xi} ; 50$ for $\$ 1.95 ; 100$ for $\$ 3.75$.

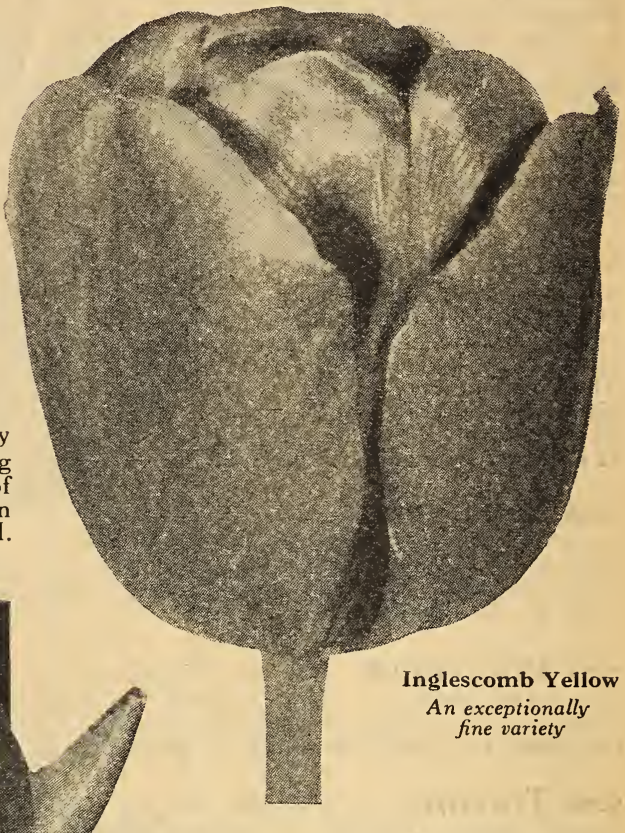

9215 Inglescomb Yellow This is planted extensively together with all the different colors of the Darwin varieties because the latter class does not contain any bright yellow shades. The golden yellow flowers are of largest size and perfect form. They are heavy, bold, and of massive appearance. The heavy texture of the petals makes it one of the most lasting of all Tulips. 19 inches tall. 6 for $35 \phi$; 12 for $60 \dot{\phi} ; 50$ for $\$ 2.10 ; 100$ for $\$ 4.00$.

9212 Idyll A charming variety with blooms of grand size, heavy texture, and carried on strong stems. The color is a rich yet delicate rose with a fine satiny sheen. On the inside the petals show an excellent salmon-pink cast overlying the rose-pink ground color. Those who have a special liking for delicate shades should not miss this. 6 for $45 \dot{\phi} ; 12$ for $85 \dot{\phi} ; 50$ for $\$ 3.10 ; 100$ for $\$ 6.00$.

9221 Moonlight This excellent variety is a lovely shade of soft canary-yellow. The flowers are of an oval shape with the outer petals reflexing at the tips. A strong and sturdy grower which makes a fine display in the open and is also grown extensively for late forcing indoors. The flowers look their best when the petals recurve completely, forming a beautiful and graceful star of rare beauty. 6 for $40 \dot{\phi}$; 12 for $70 \dot{\phi} ; 50$ for $\$ 2.60$; 100 for $\$ 5.00$. 
9220 Mrs. Moon This is an excellent flower of a shape often called Lily Tulips. The blooms when closed are quite long, but when they begin to open the fairly narrow petals spread out so that the flower resembles a typical Lily in form. The color is a deep lemon-yellow of great appeal. When the flowers begin to open, just the tips of the petals are reflexed. When fully developed the flower appears as a great star. A free bloomer and strong grower; 25 inches tall. 6 for $45 c$; 12 for $85 \notin ; 50$ for $\$ 3.10 ; 100$ for $\$ 6.00$.

\section{Scarlet Emperor}

A most stately and majestic flower, carried on a fine long stem. The color is a brilliant and glowing scarlet with the center of the blooms shading into a clear yellow. Scarlet Emperor is a flower of gigantic size and heavy texture. 6 for $45 k ; 12$ for $85 k ; 50$ for $\$ 3.10 ; 100$ for $\$ 6.00$.

9226 Sirene This is classed as a Lily-flowering variety, as the comparatively narrow petals curve back when the flower begins to open, thereby resenbling a Lily in shape. The color is rich cerise-pink with a pale pink margin and a white base. 6 for 50 ; 12 for $95 k ; 50$ for $\$ 3.60 ; 100$ for $\$ 7.00$.

9233 Sir Harry See illustration. This is an unusually fine shade of soft lavender-pink. The inside of the petals is relieved by a yellow base and a steelblue halo. The flowers are large, with pointed petals and broad at the base. They are Sir Harry carried upright on Iong stems; 26 inches tall. Lavender-pink 6 for $40 \xi ; 12$ for $75 \phi ; 50$ for $\$ 2.85 ; 100$ for $\$ 5.50$.

9234 The Fawn A well-shaped flower of wonderful size. When the flowers begin to open they are a lovely and cheerful shade of rosy amber. Later when they open up more fully they change to a warm cream shade, artistically splashed with a faint delicate shade of rose; 18 inches tall. 6 for $35 \mathrm{c}$; 12 for $65 \dot{c} ; 50$ for $\$ 2.35 ; 100$ for $\$ 4.50$.

9236 Cottage Tulips, Mixed A fine assortment of all the best Cottage Tulips which will give excellent results. This mixture will give a good show if planted in masses, or clumped amid perennials, or to supplement the planting of shrubs. 6 for 30 ; 12 for 50 ; 50 for $\$ 1.70 ; 100$ for $\$ 3.25$; 500 for $\$ 15.50 ; 1000$ for $\$ 30.00$.

\section{Collections of COTTAGE TULIPS}

These collections contain the following showy and free-blooming Cottage Tulips: Gesneriana Major, Inglescomb Pink, Inglescomb Yellow, Picotee, Orange King, and The Fawn.

9765 - 6bulbseach ( 36 bulbs, value $\$ 2.00$ ), $\$ 1.60$

9766-12 bulbs each ( 72 bulbs, value 3.55 ), 2.75

9767-25 bulbs each (150 bulbs, value 6.50$), \quad 5.00$

9768 - 50 bulbs each (300 bulbs, value 12.55), 9.50
9229 Picotee (Maiden's Blush) Here is a variety of outstanding beauty and great artistic appeal. The shape of the flowers is not unlike that of a Lily. The ground color is white with a broad margin of deep rose. The graceful habit of the flowers adds to their interesting appeal whether used for garden display or for cutting; 22 inches tall. 6 for 30 c; 12 for 55 c; 50 for $\$ 1.95$; 100 for $\$ 3.75$.

9223 Orange King This Tulip should be in every garden. Orange King always draws the greatest admiration. It is a lovely flower of extreme size and artistic proportions. Whether planted in beds or borders or used for cut-flowers, Orange King will give entire satisfaction.

The color of the flowers is a glistening deep orange with a lovely cast of rose on the outside of the petals. The inside is a deep orange-scarlet relievedby an edge ofbright yellow at the base. This combination of tints has a scintillating sheen in bright sunlight. This variety is remarkably sweet scented; 19 inches taII. 6 for 35 ; 12 for 60 d; 50 for $\$ 2.10$; 100 for $\$ 4.00$.

\begin{tabular}{|} 
Buy your bulbs \\
direct from \\
Burpee in \\
Philadelphia
\end{tabular}

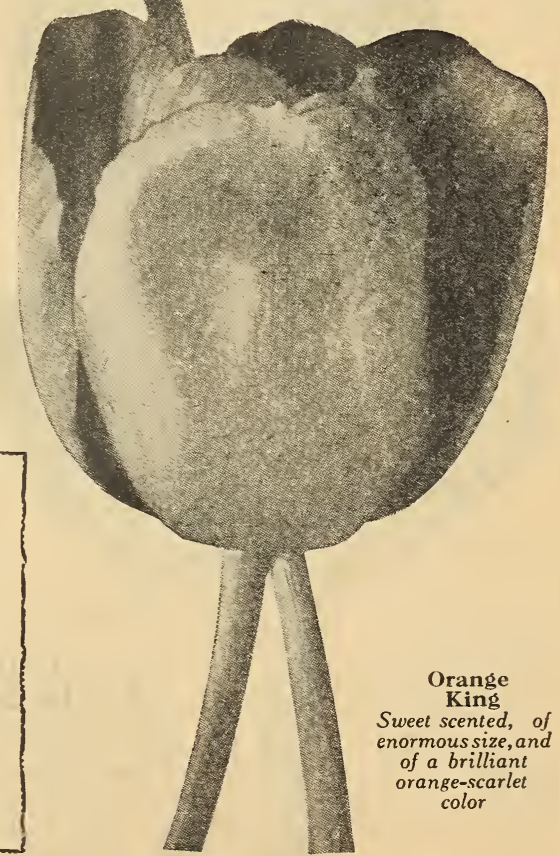




\section{EARLY SINGLE TULIPS}

Outdoors: These are the first Tulips to come into bloom early in the spring, and they are planted extensively in beds, .borders, or clumped together among perennials and in the foreground of shrubbery. They may be had in a magnificent assortment of bright colors. Ask for the Burpee leaflet, "Bulbs for Winter and Spring Blooming," which gives complete planting directions.

9106 Belle Alliance Showy brilliant scarlet blooms of excellent size, well-rounded form, and carried on strong substantial stems. The richness of the color has made this a very popular variety both for bedding and forcing. 6 for $40 \phi$; 12 for $70 \phi ; 50$ for $\$ 2.60 ; 100$ for $\$ 5.00$.

9108 Chrysolora Clear golden yellow blooms of a richness and brilliancy that is hard to surpass. The blooms are large, of globular shape, and excellent for bedding purposes. A stately variety growing 11 inches talI. 6 for $40 \dot{\phi}$; 12 for $70 \dot{\phi} ; 50$ for $\$ 2.60 ; 100$ for $\$ 5.00$.

9105 Couleur Cardinal Large flowers of a velvety crimson-cardinal color with yellow in the center and shaded plum on the outside. 6 for $40 \notin ; 12$ for $70 \xi ; 50$ for $\$ 2.60 ; 100$ for $\$ 5.00$.

9109 Crimson Brilliant Rich glowing crimson-scarlet flowers, carried on fine strong stems. An excellent garden and forcing variety, growing 14 inches tall. 6 for $35 \phi ; 12$ for $60 \phi$; 50 for $\$ 2.10 ; 100$ for $\$ 4.00$.

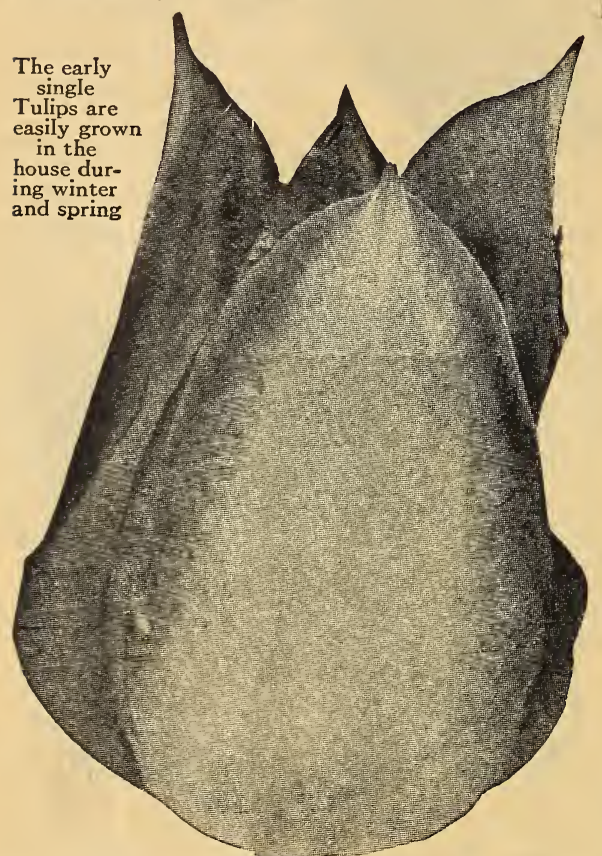

Fred Moore

An outstanding variety with large flowers of an artistic form and appealing rosy terra-cotta color. Fine for early forcing
In the House: The early single Tulips are grown extensively in pots or pans for indoor blooming. They make the best display if planted not less than six bulbs in a shallow pan, one variety to a pot, to be sure that they will bloom at the same time. The flowers are supported by strong [stems and bloom for a long time.

9110. De Wet This is a most outstanding early single Tulip which is always greatly admired because the flowers are of extra large size, massive, and substantial. It is a golden yellow attractively shaded with deep orange. The sweet-scented blooms are particularly suited for forcing. Grows 14 inches tall. 6 for $85 \phi ; 12$ for $\$ 1.60 ; 50$ for $\$ 6.10 ; 100$ for $\$ 12.00$.

9111 Diana We consider this the best early single white Tulip in existence. The flowers are remarkably large, solid, and pure white. They are excellent for bedding or forcing. 6 for 35 ; 12 for $60 \% ; 50$ for $\$ 2.10 ; 100$ for $\$ 4.00$.

9114 Fire Prince (Prince of Austria)

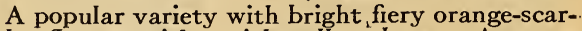
let flowers with a rich yellow base. A strong: grower, fine for the garden and very much used for forcing; 15 inches tall. 6 for $35 \phi ; 12$ for $65 \phi$; 50 for $\$ 2.35 ; 100$ for $\$ 4.50$.

9120 Keizerskroon One of the most popular and showiest of all Tulips, with a broad edge of rich golden yellow around a vivid crimson-scarlet blotch; 16 inches tall. 6 for $45 \dot{\xi} ; 12$ for $85 \dot{\xi} ; 50$ for $\$ 3.10 ; 100$ for $\$ 6.00$.

9115 Flamingo Deep rich rose flowers with a distinct white stripe through the center of each petal. The color is rich yet delicate. Flamingo is a popular variety for garden display and for winter forcing. Grows 13 inches tall and makes a wonderful show. 6 for $35 \phi ; 12$ for $65 \dot{6} ; 50$ for $\$ 2.35 ; 100$ for $\$ 4.50$.

9122 L'Esperance This magnificent early Tulip has Iarge well-formed flowers of a bright rosy lilac edged white. A strong and sturdy grower. A truly exquisite variety. 6 for 35 12 for $65 \phi ; 50$ for $\$ 2.35 ; 100$ for $\$ 4.50$.

9131 Rose Luisante A fine satiny rosea most appealing shade. Good for forcing and the open ground; 13 inches tall. 6 for $40 \dot{\xi}$ 12 for $70 \notin ; 50$ for $\$ 2.60 ; 100$ for $\$ 5.00$.

9129 Rising Sun This deep golden yellow Tulip has handsome flowers of enormous size. Fine for bedding or forcing; 16 inches tall. 6 for $45 \dot{\xi} ; 12$ for $85 \dot{c} ; 50$ for $\$ 3.10 ; 100$ for $\$ 6.00$.

9113 Fred Moore Terra-cotta with a rosy sheen, shaded old gold on the edges. Sweet. scented, fine for forcing; 15 inches tall. 6 for $35 \phi ; 12$ for $60 \phi ; 50$ for $\$ 2.10 ; 100$ for $\$ 4.00$.

9139 Yellow Prince A very fine yellow, sometimes streaked with dull orange and terracotta. A useful bedding and forcing variety. 6 for $35 \dot{\xi} ; 12$ for $60 \dot{\xi} ; 50$ for $\$ 2.20 ; 100$ for $\$ 4.25$. 


\section{EARLY DOUBLE TULIPS}

The culture of the double varieties is as easy as that of the singles. Planted in pans, they make attractive winter-bloomers and Iast even longer than the single varieties. They are ideal for outdoor bedding because they make a compact growth and bloom longer than any other type. Of uniform height and massive appearance.

9356 Crown of Gold Rich yellow splashed with orange and red. A glorious flower. 6 for $40 \xi$; 12 for 70 \&; 50 for $\$ 2.60 ; 100$ for $\$ 5.00$.

9358 Electra An excellent new variety with large double rosy violet blooms. 6 for $45 \notin$; 12 for 85 ; 50 for $\$ 3.10 ; 100$ for $\$ 6.00$.

9363 Mr. Van Der Hoeff A beautiful new pure yellow double flowering Tulip. 6 for $45 \phi ; 12$ for $85 \phi ; 50$ for $\$ 3.10 ; 100$ for $\$ 6.00$.

9362 Murrillo White and rose-pink, flushed and streaked; 11 inches tall. 6 for $35 \%$; 12 for $60 \phi ; 50$ for $\$ 2.10 ; 100$ for $\$ 4.00$.

9366 Peach Blossom Rose-pink attractively flushed with white; 12 inches tall. 6 for $45 \phi ; 12$ for $85 \phi ; 50$ for $\$ 3.10 ; 100$ for $\$ 6.00$.

9367 Rubra Maxima A large crimsonscarlet flower; 11 inches tall. 6 for $35 \phi$; 12 for $65 \phi ; 50$ for $\$ 2.35 ; 100$ for $\$ 4.50$.

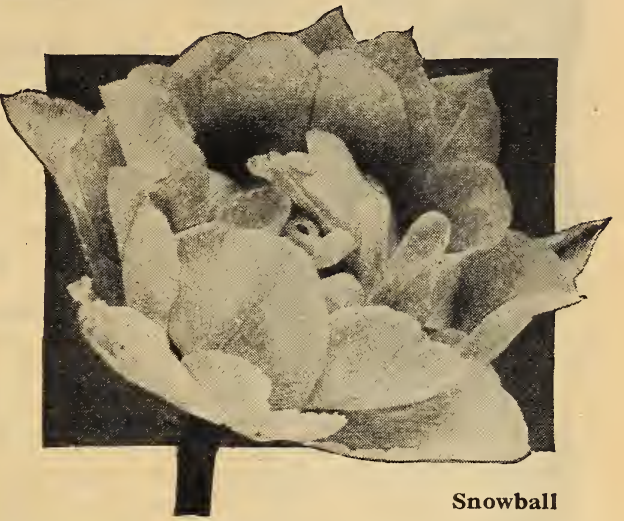

9370 Snowball See illustration. Pure white, Peony-like flowers; 10 inches tall. 6 for $35 \dot{\xi}$; 12 for $65 \dot{k} ; 50$ for $\$ 2.35 ; 100$ for $\$ 4.50$.

9380 Early Doubles, Mixed This mixture has been prepared with the utmost care to include the proper proportions of the different colors that are needed to make a colorful and showy appearance in beds, borders, or mixed plantings. 6 for $30 \dot{\phi} ; 12$ for $55 \dot{\phi} ; 50$ for $\$ 1.90$; 100 for $\$ 3.60 ; 500$ for $\$ 17.00$; 1000 for $\$ 32.50$.
9373 Tea Rose Saffron-yellow shaded with apricot. A large double flower of a charming and beautiful color combination. 6 for $35 \dot{0} ; 12$ for $65 \dot{0} ; 50$ for $\$ 2.35$; 100 for $\$ 4.50$.

9376 Turban Violet Beautiful rosy violet. 6 for $40 ; ; 12$ for $70 ; 50$ for $\$ 2.60 ; 100$ for $\$ 5.00$.

\section{Collections of Double Tulips}

These contain Mr. Van Der Hoeff, Peach Blossom, Rubra Maxima, and Snowball.

9791 - Six bulbs each ..... (24 bulbs, value $\$ 1.60), \$ \$ 1.40$ 9792-Twelve bulbs each. . (48 bulbs, value 3.00$), \quad 2.50$ 9793-Twenty-five each. (100 bulbs, value 5.60$), \quad 4.75$

\section{Some New and Rare Tulips}

9390 Aegir This is an excellent novelty with large flowers of a brilliant orange shaded with cerise. It makes a very attractive display and is of stately and showy habit. 3 for $65 \dot{\phi} ; 6$ for $\$ 1.25 ; 12$ for $\$ 2.40 ; 100$ for $\$ 18.00$.

9201 Argo A fine variety for forcing, showing up as a delicate bronze-salmon shade. Grown in the open the round, strong-stemmed blooms are yellow, mottled red, and shading into reddish brown. An outstanding new tulip. 3 for 55 ; 6 for $\$ 1.05 ; 12$ for $\$ 2.00 ; 100$ for $\$ 15.00$.

9397 Clusiana The outer petals are bright cherry-red and the inner ones are creamy white with a violet base. A /distinct small-flowered botanical species that is much in demand for planting in the perennial border or the rock garden. Plant 6 to 9 inches deep. 3 for $27 \phi$; 6 for 50 ; 12 for $95 k ; 100$ for $\$ 7.00$.

9392 Dulcinea A robust round flower of a glowing orange-red on the inside with a yellow and green base. The outside is vivid red. An excellent forcing variety that has made a great "hit" at all shows. 3 for $55 \notin ; 6$ for $\$ 1.05$; 12 for $\$ 2.00$; 100 for $\$ 15.00$.
9213 Marvel A decidedly sweet-scented variety of recent introduction. The inside of the petals is old gold and the outside is rose edged with yellow. Fine for forcing or for the garden, growing 25 inches tall. 3 for $75 k ; 6$ for $\$ 1.40$; 12 for $\$ 2.65 ; 100$ for $\$ 20.00$.

9211 Nectar A very effective garden Tulip of a fiery crimson color with a pure white base. The petals are slightly reflexed. Fine for the garden and excellent for early forcing. 3 for $45 \phi$; 6 for $85 \phi ; 12$ for $\$ 1.60 ; 100$ for $\$ 12.00$.

9332 Vesta This is a wonderful novelty with long stems. Strong flowers of a pure white texture. It has proven to be a very good early forcing variety. 3 for $45 \xi ; 6$ for $85 \xi ; 12$ for $\$ 1.60 ; 100$ for $\$ 12.00$.

\section{Collections of Rare Tulips}

These include the seven unusual and rare new varieties described here.

9728-Three each. . (21 bulbs, value $\$ 3.67) \$ 2.75$

9729-Six each.... (42 bulbs, value 6.95$) \quad 5.00$

9730-Twelveeach. (84 bulbs, value 13.20 ) 9.50 


\section{REMBRANDT TULIPS}

In general habit of growth these resemble the popular Darwin Tulips. AII are
striped or splashed with a rich shade on lighter ground. Very beautiful.

302 Bougainville This is an excellent forcing variety. The ground color is a rich Amaranth which is striped with white. 6 for $45 \dot{c} ; 12$ for $85 \dot{c} ; 50$ for $\$ 3.10 ; 100$ for $\$ 6.00$.

9305 Caracalla Rich fiery scarlet stripes upon a white ground. 6 for $45 \dot{\xi} ; 12$ for $85 \dot{\varepsilon} ; 50$ for $\$ 3.10 ; 100$ for $\$ 6.00$.

9313 Hebe White, attractively relieved by stripes of lilac and maroon. 6 for $45 \dot{c} ; 12$ for $85 \dot{\xi} ; 50$ for $\$ 3.10 ; 100$ for $\$ 6.00$.

9321 Red Prince Fiery scarlet upon a soft rose ground. Large

$\begin{aligned} & \text { Red } \\ & \text { Prince }\end{aligned}$
and well formed. 6 for $45 \dot{\xi} ; 12$ for $85 \dot{\xi} ; 50$ for $\$ 3.10 ; 100$ for $\$ 6.00$.
9326 Semele Bright pink stripes upon a white background. A
showy variety. 6 for $45 \dot{\xi} ; 12$ for $85 \dot{\xi} ; 50$ for $\$ 3.10 ; 100$ for $\$ 6.00$.

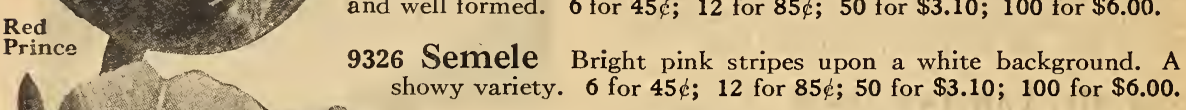

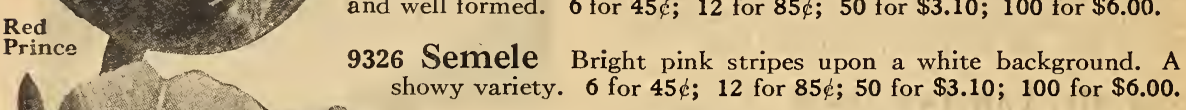
9330 Suzanna Rich reddish brown markings on a soft lilacwhite ground. 6 for $45 \dot{\xi} ; 12$ for $85 \xi ; 50$ for $\$ 3.10 ; 100$ for $\$ 6.00$.

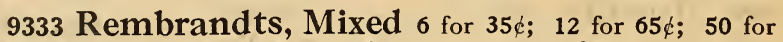
$\$ 2.35 ; 100$ for $\$ 4.50 ; 500$ for $\$ 21.00 ; 1000$ for $\$ 40.00$.

\section{Collections of Rembrandt Tulips}

These collections contain the four varieties: Bougainville, Caracalla, Hebe, and Semele.

9786 - Three each ........ (12 bulbs, value $\$ 1.00)$, $\$ 0.85$

9787-Six each .......... (24 bulbs, value 1.80$), \quad 1.50$

9788-Twelve each ........ (48 bulbs, value 3.40$), \quad 2.75$

Hebe 9789-Twenty-five each...(100 bulbs, value 6.40$), \quad 5.00$

\section{PARROT TULIPS}

The Parrot Tulips are of most artistic and quaint form. They are grown outdoors as well as in the house and are highly valued for cut-flowers. The petals of the blooms are laciniated and slashed on the edges, as will be seen in the accompanying illustration. The blooms are large and of striking colors. They are carried on slender stems 14 to 15 inches in height and bloom in the open during the month of May. Because the stems are comparatively slender,

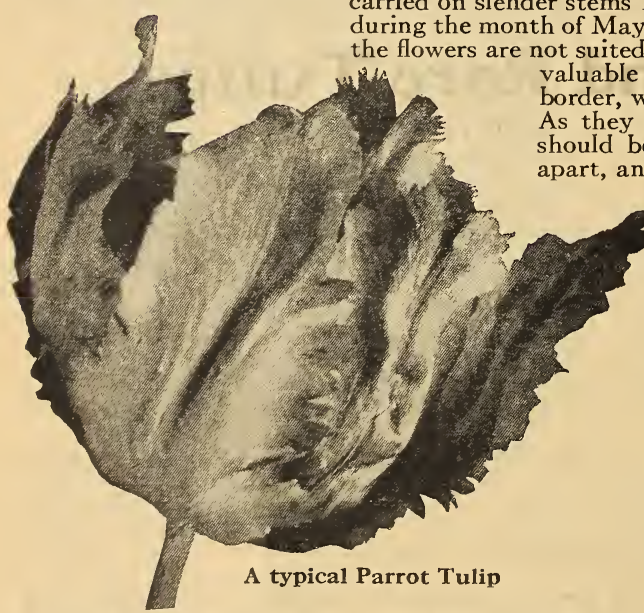

\section{Collections of Four Parrot Tulips}

These include the four separate varieties: 9749-Six each.......... (24 bulbs, value $\$ 1.40) \$ 1.20$ 9750-Twelve each...... (48 bulbs, value 2.60$) \quad 2.00$
9338 Coffee Color A very striking combination of brown and yellow shades. A most artistic and handsome flower. 6 for $35 \dot{k}$; 12 for $65 \dot{\xi} ; 50$ for $\$ 2.35 ; 100$ for $\$ 4.50$.

9339 Cramoisi Brilliant This will appeal to many gardeners, with its large deep crimson flowers. 6 for $35 \dot{\xi} ; 12$ for $65 \dot{k}$; 50 for $\$ 2.35 ; 100$ for $\$ 4.50$.

9343 Lutea Major A clear yellow flower with a few stripes and blotches of crimson and green-very odd and striking. 6 for $35 \dot{0}$; 12 for $65 \dot{\varepsilon} ; 50$ for $\$ 2.35 ; 100$ for $\$ 4.50$.

9346 Perfecta A greenish yellow ground attractively striped with light scarlet. This is a very odd combination. 6 for $35 k$; 12 for $65 \dot{k} ; 50$ for $\$ 2.35 ; 100$ for $\$ 4.50$.

9353 Superfine, Mixed A mixture of many outstanding self colors and combinations which are excellent for the mixed border. 6 for $35 \phi ; 12$ for $60 \phi ; 50$ for $\$ 2.05 ; 100$ for $\$ 4.00 ; 500$ for $\$ 18.00 ; 1000$ for $\$ 35.00$. 


\section{Scilla-Bluebell}

Scillas play an important part for planting in borders and for use as cut-flowers. They bloom in the open during March and April, when planted in October or November. The tops of the bulbs should be covered with about three inches of fine soil and the bulbs should be spaced four to five inches apart. During real winter weather a covering of straw is advisable. For mass effect plant the bulbs in quantity. Let them remain for several years in the same place and they will increase in number, size, and beauty.

For pot-culture, place three to frve bulbs in a pan and treat the same as you would Hyacinths or Tulips. Water sparingly until the buds appear, and give them a place where they can get all the sunlight possible. Grown indoors, the blooms develop best if the plants are kept at 35 to 48 degrees Fahrenheit.

9490 Sibirica A popular variety on account of its extremely rich blue flowers, which appear about the same time as the Snowdrops. 6 for $35 \dot{c} ; 12$ for $65 \phi ; 50$ for $\$ 2.35 ; 100$ for $\$ 4.50$.

9491 Campanulata The beautiful bell-shaped sky-blue flowers are borne on slender stems during May and June.

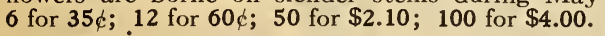

\section{Grape Hyacinths}

Grape Hyacinths look well either naturalized, planted in the perennial border, or set as edgings to beds of Hyacinths, Tulips, Narcissus, and other spring-blooming bulbs.

They do best in a medium heavy soil which is well drained and porous. The graceful flower-spikes appear early in April. The flower-stems are six inches or more in length and are covered with miniature bells. Plant in the fall as soon as the bulbs can be had. Cover them with an inch or two of fine soil, setting the bulbs three to four inches apart. During particularly severe winter weather a covering of straw or strawy manure is necessary to protect them against severe frosts.

Grape Hyacinths are also grown extensively for winterblooming indoors. They require a cool temperature to develop properly and cannot be forced into bloom by heat. Plant ten to twenty bulbs closely together in a shallow pan filled with sand and give the same treatment as you would to Crocus.

9485 Heavenly Blue This is by far the most beautiful of the blue shades, with many fine small bells on a stem. 12 for 50 ; ; 50 for $\$ 1.85 ; 100$ for $\$ 3.50 ; 500$ for $\$ 16.50$.

9486 White This is a white-flowered variety of the popular Grape Hyacinth. In freedom of bloom and attractiveness it vies with Heavenly Blue, and the two look very well planted together. 12 for $70 \notin ; 50$ for $\$ 2.60 ; 100$ for $\$ 5.00$.

\section{Miniature Hyacinths}

Very attractive Hyacinths of miniature size and graceful appearance. The single blooms are set on rather slender stems. These Hyacinths are very fine for potting during winter, placing the bulbs quite closely together, or they may be planted outdoors 4 to 5 inches apart. They are entirely hardy and bloom profusely early in the season. Their graceful habit makes them particularly valuable for this purpose.

9040 Enchantress A lovely light delft-blue shaded with a harmonizing deeper shade of blue. Makes a graceful spike. 9042 King of the Blues The rich dark blue bells are carried on fine slender stems. Blooms very profusely.

9046 Lady Derby Clear rose-pink flowers that make a good showing whether grown outdoors or in the house.

9049 La Victoire An excellent brilliant scarlet variety which is somewhat lighter if grown in the house.

9052 L'Innocence We consider this the very best of all white Hyacinths. Bears a profusion of waxy white bells.

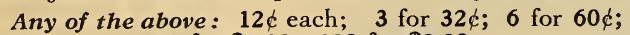

12 for $\$ 1.10 ; 100$ for $\$ 8.00$.

9055 Miniature Mixed This is a complete mixture of all the various colors of Miniature Hyacinths. $10 \notin$ each; 3 for $27 \xi ; 6$ for $50 \phi ; 12$ for $95 \phi ; 100$ for $\$ 7.00$.

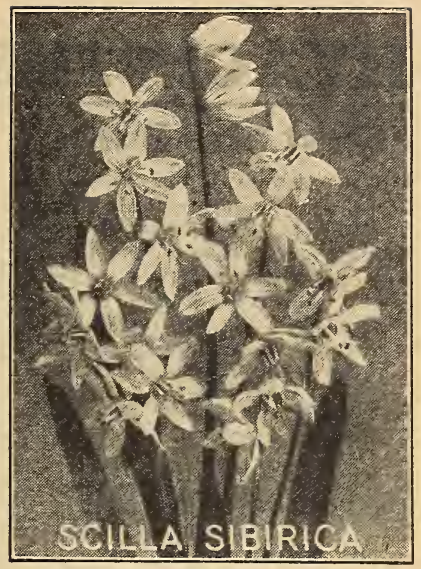

Scillas are splendid for naturalizing because they thrive in shady places where many other flowers will fail

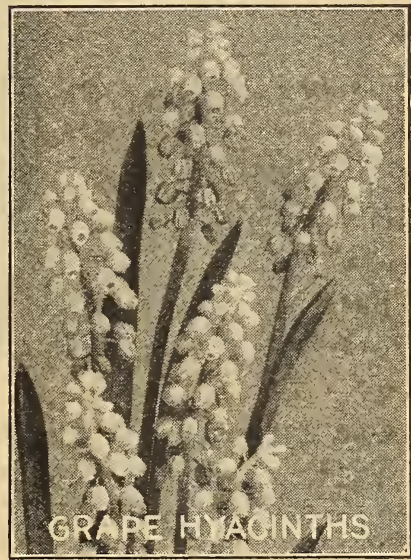

These hardy little bulbs should be planted in masses

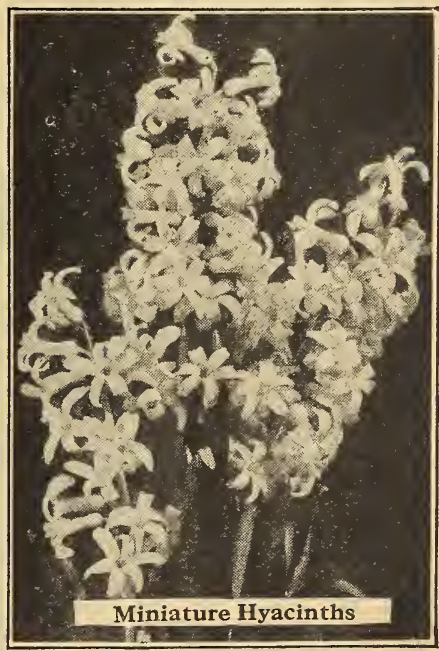

The Dutch Miniature Hyacinths are unique for mass planting 
Outdoors: Hyacinths are wonderfully well adapted to planting in beds outdoors, and the attractive display of colors early in the spring is a source of great pleas-
ure to the flower lover. They are easily grown outdoors, planted in the faII, and covered with straw or strawy manure.

In the House: Hyacinths can be had in full blooin in pots, pans, or boxes throughout the winter and until Iate in the spring. Their delicate perfume and rich gay coloring are always wel-
come. There are no bulbs easier to raise indoors for blooming during the winter than Hyacinths.

They can be grown either in pots filled with soil or in glasses filled with water. Success with both methods depends on getting the bulbs to make a strong root growth before the top growth begins. This is accomplished by setting the pots or glasses in a cool, airy, and dark place for a period of from 4 to 8 weeks. Afterward they are brought to light and kept at a temperature of from 50 to 60 degrees Fahrenheit until the flowers begin to open up.

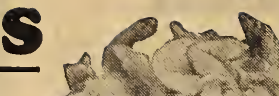

9009 King of the Blues Illustrated on the inside front cover. This outclasses all other deep blue varieties on account of its purity and richness of color. The individual flowerspikes are long and they are fully set with large bells of a rich dark blue color. It is most useful if planted together with any of the lighter shades to bring out its rich color.

King of the Blues is a very good late forcing variety and also makes a fine show in the tlower-bed. Of even height, with all flowers coming into bloom at the same time. 25 \& each; 3 for $65 \phi ; 6$ for $\$ 1.25$; 12 for $\$ 2.40 ; 100$ for $\$ 18.00$.

9007 Grand Maitre See illustration. A glorious spike of Iarge bells closely set on a long and strong stem. The color is a rich deep porcelainblue of unusual appeal and Iasting quality. Excellent for bedding, but just as useful as a forcing variety. It is somewhat slower than other varieties when forced indoors. Because of its compact habit and solid spike of color it is used very widely for potplants. 25 each; 3 for 65 6 ; 6 for $\$ 1.25$; 12 for $\$ 2.40$; 100 for $\$ 18.00$.

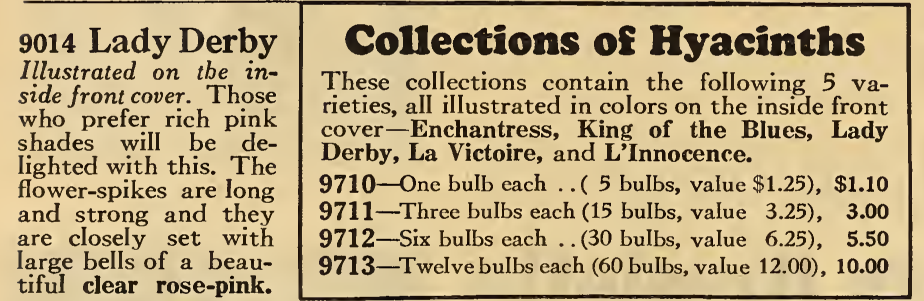

Grown in theopen as a bedding variety, it is simply beautiful, but it is also easily forced, making fine potplants. Grown indoors the flowers are of a slightly deeper shade. The illustration shows the wonderful habit of the plants and the glorious spikes of flowers they make. It is a sturdy variety with a delightful and refreshing fragrance. 25 $c$ each; 3 for $65 \notin ; 6$ for $\$ 1.25 ; 12$ for $\$ 2.40 ; 100$ for $\$ 18.00$.

We offer large size bulbs, $21 / 4$ to 238 inches in diameter, the size best suited for forcing as well as for outdoor planting.

\section{Enchantress}

Illustrated on the inside front cover. A lovely Hyacinth with long and attractive flowerspikes. The individual bells are closely set on the stem, completely covering it. They are of a beautiful light delft-blue shaded with a somewhat deeper blue.

Enchantress is an early bloomer, valuable for bedding and fine for forcing in pots or in special Hyacinth glasses. It is a standard variety which has been grown and carefully selected for many years by the best Dutch Hyacinth growers, and our present strain is noteworthy for the uniformity of the flower-spikes. This is very important where Hyacinths are grown for bedding purposes, as the plants must be all of the same height and bloom at the same time to give a perfect display.

$25 \dot{c}$ each; 3 for $65 \phi ; 6$ for $\$ 1.25$; 12 for $\$ 2.40 ; 100$ for $\$ 18.00$. 
9006 Gertrude See illustration. Gertrude is a pretty and charming variety of a rich carmine-rose shade. It is a great favorite for outdoor bedding because the plants make a uniform growth and come into bloom all at one time. This is very important in varieties which are grown for bedding.

Gertrude is also a very fine forcing variety, easily grown either in potsor water. The spikes are strong and sturdy and are closely set with large, well-shaped bells. When in full bloom a spike is just a solid mass of color, standing out sharply from the rich green foliage. Gertrude remains in full bloom for a long time. 25 ceach; 3 for 65 ; 6 for $\$ 1.25 ; 12$ for $\$ 2.40$; 100 for $\$ 18.00$.

9019 La Victoire $I l$ lustrated on the inside front cover. One of the earliest of aII Hyacinths to come into bloom. It is an excellent bedding variety, with long stems, staying in full bloom for an exceptionally long time. The color of the flowers grown outdoors is a brilliant scarlet. When grown under glass it is somewhat lighter. La Victoire is used extensively as a pot-plant, as it forces very easily and makes a very large spike. $25 \dot{k}$ each; 3 for $65 \dot{c}$; 6 for $\$ 1.25 ; 12$ for $\$ 2.40$; 100 for $\$ 18.00$.
9023 L'Innocence Illustrated on the inside front cover. L'Innocence is the best of all white Hyacinths for all purposes. It is an extra-early variety, bearing long spikes which are closely set with magnificent white bells. Grown in beds it makes a beautiful display, but it is also used extensively for growing in pots or in water for winter and early spring blooming in the house. One of the earliest and most dependable for Christmas and early spring forcing. $25 \notin$ each; 3 for $65 \notin ; 6$ for $\$ 1.25 ; 12$ for $\$ 2.40 ; 100$ for $\$ 18.00$.

9027 Marconi The color of this splendid variety is a shade deeper than Lady Derby. It is a bright deep rose, attractively flushed with white. Marconi is highly recommended, particularly for outdoor planting, where it develops handsome and heavy spikes carried on strong, heavy stems. 25c each; 3 for $65 \dot{c}$; 6 for $\$ 1.25$; 12 for $\$ 2.40$; 100 for $\$ 18.00$.

9031 Yellow Hammer

It is easily forced and forms large compact spikes well set with rich creamy yellow bells. Blooms early and is fine for forcing or bedding. 25 each; 3 for $65 \phi$; 6 for $\$ 1.25$; 12 for $\$ 2.40$; 100 for $\$ 18.00$.

\section{Second Size Bulbs of Hyacinths}

The bulbs of the Second Size Hyacinths are about $21 / 8$ inches in diameter. Many gardeners prefer this size for forcing. Excellent for Deuiing purposes and the bulbs are sure to bloom if they are given avarage care. Fuil descriptions of all these varieties are given above and on the opposite page.

9005 Enchantress Light blue.

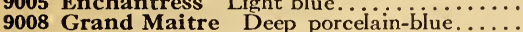

9010 King of the Blues Dark blue.

9015 Lady Derby Clear rose-pink ............

9011 Gertrude Brilliant carmine-rose.....

9020 La Victoire Brilliant scarlet.

9024 L'Innocence The finest white

9028 Marconi Rose flushed white

9032 Yellow Hammer Creamy yellow..

\section{Mixed Hyacinths for Bedding}

Where Hyacinths are planted among perennials or in the foreground of shrubbery and certain colors are preferred to a general mixture, these color mixtures will provide a fine display as they show an agreeable variation of tints which gives a beautiful effect.

\section{Collections}

\section{of Five Hyacinths}

(Second Size Bulbs)

These assortments contain Enchantress, King of the Blues, Lady Derby, La Victoire, and L'Innocence.

97151 each ( 5 bulbs). $\$ 0.90$

97163 each (15 bulbs) 2.50

97176 each (30 bulbs) 4.75

971812 each (60 bulbs) 9.00
9061 Dark Red Shades This includes a number of single dark red varieties which will give a fine effect. $15 \phi$ each; 3 for $40 \phi ; 6$ for $75 \phi$; 12 for $\$ 1.45 ; 100$ for $\$ 12.00$.

9062 Pink Shades A lovely mixture of

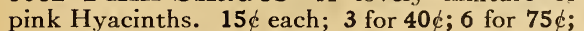
12 for $\$ 1.45 ; 100$ for $\$ 12.00$.

9067 Rose Shades These rose-flowering Hyacinths are all very pretty. $15 \phi$ each; 3 for $40 \Leftrightarrow$; 6 for $75 \dot{k} ; 12$ for $\$ 1.45 ; 100$ for $\$ 12.00$.

9064 Dark Blue Shades A rare assortment of various dark blue flowering single Hyacinths for bedding. 15 each; 3 for $40 \dot{\phi}$; 6 for $75 \xi ; 12$ for $\$ 1.45 ; 100$ for $\$ 12.00$.
9065 Light Blue Shades The light blue single Hyacinths enjoy particular popularity with many gardeners. $15 \dot{c}$ each; 3 for $40 \dot{\phi}$; 6 for $75 \dot{\phi} ; 12$ for $\$ 1.45 ; 100$ for $\$ 12.00$.

9066 Yellow Shades From light creamy yellow to rich yellow. $15 \dot{\phi}$ each; 3 for $40 \dot{\phi}$; 6 for $75 \dot{\phi} ; 12$ for $\$ 1.45 ; 100$ for $\$ 12.00$.

9063 White Shades These are various white varieties which are excellent for garden display or massing. $15 \dot{k}$ each; 3 for $40 \dot{k} ; 6$ for $75 \dot{k} ; 12$ for $\$ 1.45 ; 100$ for $\$ 12.00$.

9036 All Colors Mixed A complete assortment of all the various colors of single bedding Hyacinths. 15 1 each; 3 for $40 \dot{\phi} ; 6$ for $75 \dot{\xi}$; 12 for $\$ 1.45 ; 100$ for $\$ 12.00$. 


\section{NARCISSUS and DAFFODILS}

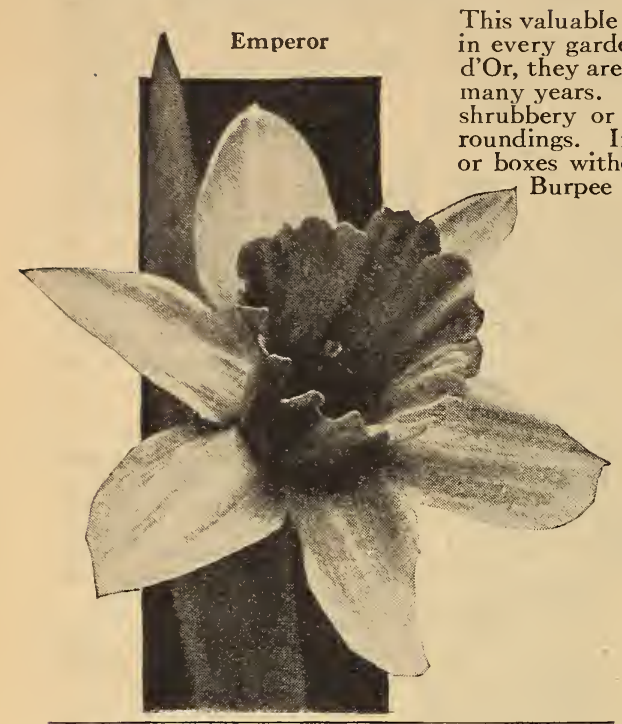

\section{Medium Trumpet}

9426 Barrii Conspicuus The light yellow perianth is made up of Iarge and broad petals. The cup is a rich yellow color edged orange-scarlet. A very showy variety; 20 inches tall. $14 k$ each; 3 for 37 ; 6 for 70 ; 12 for $\$ 1.35$; 25 for $\$ 2.60$; 100 for $\$ 10.00$.

9438 Sir Watkin A well-known variety with a sulphur-yellow perianth and a bright yellow cup tinted orange. Of immense size, hardy, sturdy, and fine for naturalizing among perennials or shrubbery; 20 inches tall. $18 \dot{e}$ each; 3 for $50 \notin$; 6 for 90 ; 12 for $\$ 1.70 ; 25$ for $\$ 3.25 ; 100$ for $\$ 12.50$.

9429 Lucifer A handsome flower composed of a fine white perianth and a medium trumpet of a glistening orange-red shade. This belongs to the Incomparabilis type. $14 \dot{c}$ each; 3 for $37 \dot{c}$; 6 for 70 ; 12 for $\$ 1.35 ; 25$ for $\$ 2.60 ; 100$ for $\$ 10.00$.

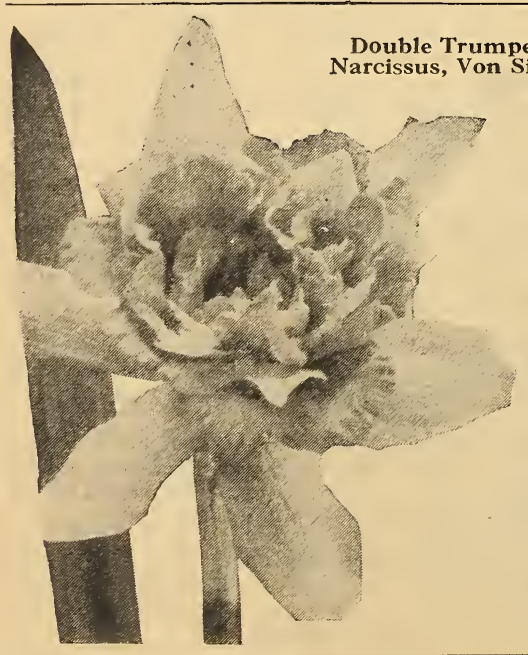

\section{Large Trumpet Daffodils} 9401 Emperor The flowers are Iarge and of heavy substance, with a deep Primrose-yellow perianth and a rich yellow trumpet. A magnificent and showy variety; grows 20 inches tall. $18 \notin$ each; 3 for $50 \notin ; 6$ for $90 \notin ; 12$ for $\$ 1.70$; 25 for $\$ 3.25 ; 100$ for $\$ 12.50$.

9403 Empress A fine large flower with a perianth composed of rather narrow petals of a sulphur-white color. The trumpet is a harmonizing shade of bright golden yellow. 18 inches tall. $18 \notin$ each; 3 for $50 \notin ; 6$ for $90 \notin ; 12$ for $\$ 1.70 ; 25$ for $\$ 3.25 ; 100$ for $\$ 12.50$.

9414 Glory of Sassenheim A very large flower with a yellow trumpet and a creamy white perianth. Long stemmed and very fragrant. $29 \dot{c}$ each; 3 for $80 \dot{k} ; 6$ for $\$ 1.50 ; 12$ for $\$ 2.90$; 25 for $\$ 5.65 ; 100$ for $\$ 22.00$.

9407 Golden Spur A large and remarkably fine flower of a uniform deep golden yellow shade. It is an excellent variety for forcing and will bloom very early if grown outdoors; 16 inches tall. $18 k$ each; 3 for $50 k ; 6$ for $90 k$; 12 for $\$ 1.70 ; 25$ for $\$ 3.25 ; 100$ for $\$ 12.50$.

9417 King Alfred The huge flowers are well rounded and of a uniform rich golden yellow; 20 inches tall. $33 \dot{c}$ each; 3 for $90 \notin ; 6$ for $\$ 1.70$; 12 for $\$ 3.25 ; 25$ for $\$ 6.40 ; 100$ for $\$ 25.00$.

9415 Olympia Pale yellow perianth with large rich yellow trumpet. A strong grower; 15 inches tall. 40 e each; 3 for $\$ 1.05 ; 6$ for $\$ 2.00$; 12 for $\$ 3.90 ; 25$ for $\$ 7.65 ; 100$ for $\$ 30.00$.

9413 Princeps A medium-size flower with a Primrose perianth and a clear yellow trumpet.

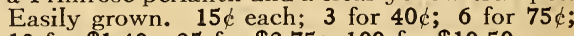
12 for $\$ 1.40 ; 25$ for $\$ 2.75 ; 100$ for $\$ 10.50$.

9418 Van Waveren's Giant A large bold flower with a soft Primrose perianth and a large, attractively waved golden yellow trumpet; 17 inches tall. 40 e each; 3 for $\$ 1.05 ; 6$ for $\$ 2.00$; 12 for $\$ 3.90 ; 25$ for $\$ 7.65 ; 100$ for $\$ 30.00$.

9420 Victoria The perianth is creamy white and the trumpet is rich yellow. Fragrant; 16 inches tall. 18 each; 3 for 50 ; 6 for 90 ; 12 for $\$ 1.70 ; 25$ for $\$ 3.25 ; 100$ for $\$ 12.50$.

\section{Double Trumpet Narcissus}

9446 Primrose Phoenix An appealing double Daffodil of a large rose shape. The color is a fine lemon-Primrose - soft and pleasing. Very showy flowers of magnificent size. $18 k$ each; 3 for $50 k$; 6 for $95 k$; 12 for $\$ 1.80 ; 25$ for $\$ 3.50 ; 100$ for $\$ 13.50$.

9445 Von Sion This fine Double Trumpet variety has large flowers of a lovely golden yellow color. One of the best for forcing since the large flowers Iast a long time in water. Also good for the open border; 12 inches tall. $20 \notin$ each; 3 for $55 \dot{c} ; 6$ for $\$ 1.05$; 12 for $\$ 2.00 ; 25$ for $\$ 3.85 ; 100$ for $\$ 15.00$. 
9460 Paper White (Polyanthus)

These American grown bulbs are the best obtainable. They can be depended upon to give good results but should not be planted before the end of November. This large-flowered Paper White variety is quite often referred to as "Chinese Sacred Lily," which it closely resembles. The clusters of blooms contain 6 to 12 flowers each and are carried on Iong stems. Easily grown in water and pebbles during the winter. 6 for $65 \phi$; 12 for $\$ 1.20 ; 25$ for $\$ 2.35 ; 100$ for $\$ 9.00 ; 500$ for $\$ 43.50 ; 1000$ for $\$ 85.00$.

9456 Poeticus Ornatus Perfectly hardy, beautiful, and sweet-scented flowers produced early in the spring. The blooms measure 2 to $21 / 2$ inches in diameter and the perianth is a pure white, sharply contrasting with the cup, which is a rich saffron-yellow edged bright crimson. Excellent for mass planting among shrubs and easily grown in pots indoors. Fine for cutting; 18 inches tall. 3 for $34 \dot{0} ; 6$ for $65 \dot{\phi}$; 12 for $\$ 1.25 ; 25$ for $\$ 2.45 ; 100$ for $\$ 9.50$.

9458 Pheasant's Eye (Poeticus) An excellent garden variety for mass planting where a natural effect is desired. Also most showy if grown indoors in pots. The large flowers have a snow-white perianth and the cup is bright scarlet. It should be planted in rather dry soil since the plants do not bloom profusely if kept too wet.

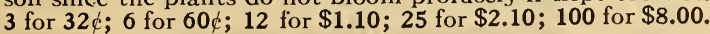

9452 Elvira (Poetaz) Good sized flowers borne in clusters of from 2 to 6 on a strong stem. The perianth is pure white and the cup is a contrasting rich yellow color. This variety grows about 18 inches tall and is well adapted for outdoor planting or for growing in the house during the winter. The Poetaz type of Daffodils is quite often called Hardy Cluster-Flowered Daffodils. They are hybrids originating from crosses between the hardy Poeticus type and the freeblooming Polyanthus type. Extremely hardy, vigorous, and valuable for bedding or forcing. 3 for $37 \dot{\phi}$; 6 for $70 \xi$; 12 for $\$ 1.35 ; 25$ for $\$ 2.60 ; 100$ for $\$ 10.00$.

\section{Mixed Daffodils}

Many of our friends have requested us to furnish them with a mixture of Narcissi which could be used for mass planting in the garden, the woodIand, or the meadow. Our mixture contains all hardy varieties suited for this purpose. The plants will multiply from year to year and give the natural effect so much desired. 6 for $50 \phi$; 12 for 95 ; 25 for $\$ 1.85 ; 100$ for $\$ 7.00 ; 500$ for $\$ 33.50 ; 1000$ for $\$ 65.00$.

\section{Collections of Five Large Daffodils}

These collections contain the following large flowering varieties described on the opposite page: Emperor, Princeps, Victoria, Von Sion, and Barrii Conspicuus.

9724-Three bulbs each, for ....\$1.95

(15 bulbs, value $\$ 2.32$ )

9725-Six bulbs each, for ...... 3.60

(30 bulbs, value $\$ 4.30$ )

9726-Twelve bulbs each, for.... 6.90

(60 bulbs, value $\$ 8.15$ )

9727-Twenty-five bulbs each, for $\mathbf{1 3 . 5 0}$ (125 bulbs, value $\$ 15.70$ )
9454 Helios (Poetaz) The flowers are arranged in clusters on fine long stems. They are a pure golden yellow color: Blooms early and freely. Excellent for forcing in the house and, being very hardy, valuable for planting in the open. Planted in clumps among perennials or shrubbery, a very fine display can be created. 3 for $55 \dot{c} ; 6$ for $\$ 1.05 ; 12$ for $\$ 2.00 ; 25$ for $\$ 3.85 ; 100$ for $\$ 15.00$.

9455 Laurens Koster (Poetaz) A valuable Narcissus which is perfectly hardy and makes a fine show, with its pure white petals surrounding a delicate orange cup. Like all varieties belonging to the Poetaz type, Laurens Koster carries 2 to 6 Iarge flowers on a single stem. 3 for 50 ; 6 for 90 ; 12 for $\$ 1.70 ; 25$ for $\$ 3.25 ; 100$ for $\$ 12.50$.

\section{Single Campernelle (Jonquila)}

This type of Narcissus is well known under the name Jonquils. The small graceful blooms are carried on slender stems about $1 \frac{1}{2}$ feet tall. Perfectly hardy and free flowering, with 2 to 6 flowers of delicate perfume clustered on a single stem. The blooms are a bright golden yellow color. Jonquils are wonderful for naturalizing in the woodland or the meadow, but they are just as easily forced in pots for winter blooming. Plant the bulbs quite closely together but avoid touching one another. The dark green rush-like foliage is decidedly attractive and the mass of blooms in close plantings gives a wonderful effect

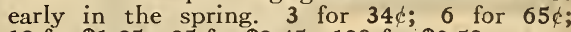
12 for $\$ 1.25 ; 25$ for $\$ 2.45 ; 100$ for $\$ 9.50$. 


\section{PEONIES}

What looks prettier than a well-grown Peony plant covered with a mass of gigantic flowers? The Peony comes into bloom at that time of the year which makes it an extremely desirable flower for use in connection with our national holiday, Memorial Day. With ordinary care the plants will bear their massive, fully double flowers in great profusion from year to year. Plant the roots during August, September, or early October in a bed well prepared and enriched with plenty of well-rotted manure. Cover the crowns with not more than 2 inches of good soil. The flowers, when cut, will last a long time in water. Most varieties as soon as they begin to open up are exquisitely scented and those offered below are the best in their color classes. Write for a free copy of the Burpee leaflet on "Peonies."

8702 Avalanche $T$ This is a crown type Peony classed as a midseason or late bloomer. A first-class variety with magnificent flowers opening up just like a rosebud. The color is snow-white with a fine delicate penciling of carmine on the edge of the center petals. Delightfully fragrant and unsurpassed by any other white Peony in existence. $60 \notin$ each; 3 for $\$ 1.60 ; 6$ for $\$ 3.10 ; 12$ for $\$ 5.85$.

8700 Baroness Schroeder A rose type late flowering variety, considered the best all-around Peony in existence. The sweet-scented flowers are extremely large and heavy, lasting remarkably long. The center is high and thick. The general color effect is a lovely baby pink, shading to white, but individual flowers vary a trifle, some of them showing a pinkish, others a salmon, and again others a Heliotrope sheen. $\$ 1.00$ each; 3 for $\$ 2.70$; 6 for $\$ 5.25$.

8705 Duchess de Nemours An early flowering crown type Peony, blooming several days after Festiva Maxima. The magnificent snow-white flowers are cup shaped with a faint green sheen when the flowers begin to pen. Later they are pure clear white. An upright branching grower, producing a mass of lovely fragrant flowers on long stems. 60 \& each; 3 for $\$ 1.60 ; 6$ for $\$ 3.10 ; 12$ for $\$ 5.85$.

8706 Edulis Superba Crown type; very early This is particularly recommended for Memorial Day blooming because it can be depended upon to bloom at that time. The color is a clear mauve-pink with a beautiful silvery sheen cast over it. The blooms are of immense size, often measuring 7 to 8 inches across. Delightfully fragrant. $60 \&$ each; 3 for $\$ 1.60 ; 6$ for $\$ 3.10 ; 12$ for $\$ 5.85$.

8713 Festiva Maxima An early flowering rose type Peony which should be in every garden. Many consider it not only the best white but the best of all early Peonies. The flowers are marvelous in every respect. They are huge, well formed, substantial, and carried on long, strong stems. The color is glistening snow-white with a few carmine dots at the edges of the center petals. Sweet scented. $65 \notin$ each; 3 for $\$ 1.75 ; 6$ for $\$ 3.30 ; 12$ for $\$ 6.00$.
8709 Felix Crousse A rose type late midseason Peony, well known because of its rich red self color - a clear shade free from any suffusion. The blooms are large, globular, solid, and substantial. The brilliant dazzling ruby-red blooms make a wonderful show, particularly if seen in bright sunlight. A free grower, producing a wealth of fine showy flowers. $90 \notin$ each; 3 for $\$ 2.50$; 6 for $\$ 4.85 ; 12$ for $\$ 9.25$.

8708 Germaine Bigot Crown type; midseason. The blooms are large and compact. They are a flattened shape when fully open. The pale lilac-rose petals are thick and substantial. The guards are attractively splashed with crimson. The collar is also splashed with crimson. Germaine Bigot is a free and continuous bloomer of strong upright habit. A wonderful showy and free-blooming variety. $75 \&$ each; 3 for $\$ 1.90 ; 6$ for $\$ 3.60 ; 12$ for $\$ 6.75$.

8707 Georgiana Shaylor A magnificent rose type variety blooming during midseason. This has always been greatly admired and, in fact, it is an outstanding variety with large, massive blooms composed of many wide petals. The color is a most charming flesh-pink, warm and soft, shading to a very delicate warm flesh-white in the center. It is a strong, vigorous variety, blooming very freely. $\$ 5.50$ each; 3 for $\$ 15.50 ; 6$ for $\$ 30.00 ; 12$ for $\$ 58.50$.

8712 Jeanne d'Arc of crown type, blooming during midseason. An extra fine flower which should be in every collection. The color is an appealing soft pink, yet rich and warm, intermingled with a beautiful silvery white, shading and enlivened by an elusive rich rose cast. The center of the flowers is spotted bright carmine. It is a most appealing and stately flower for both the garden and for cutting. $70 \&$ each; 3 for $\$ 1.80$; 6 for $\$ 3.50 ; 12$ for $\$ 6.50$.

8720 Karl Rosenfield Of semi-rose type, blooming during midseason. It was awarded first prize in 1908 as the best new Peony not in commerce at that time. Of tall stately habit with excellent velvety crimson blooms. The form of the flowers is almost round and the effect in bright sunlight is most intense and appealing. Tlose who like rich shades should include this variety in their collection. $\$ 2.00$ each; 3 for $\$ 5.40 ; 6$ for $\$ 10.00 ; 12$ for $\$ 19.00$.

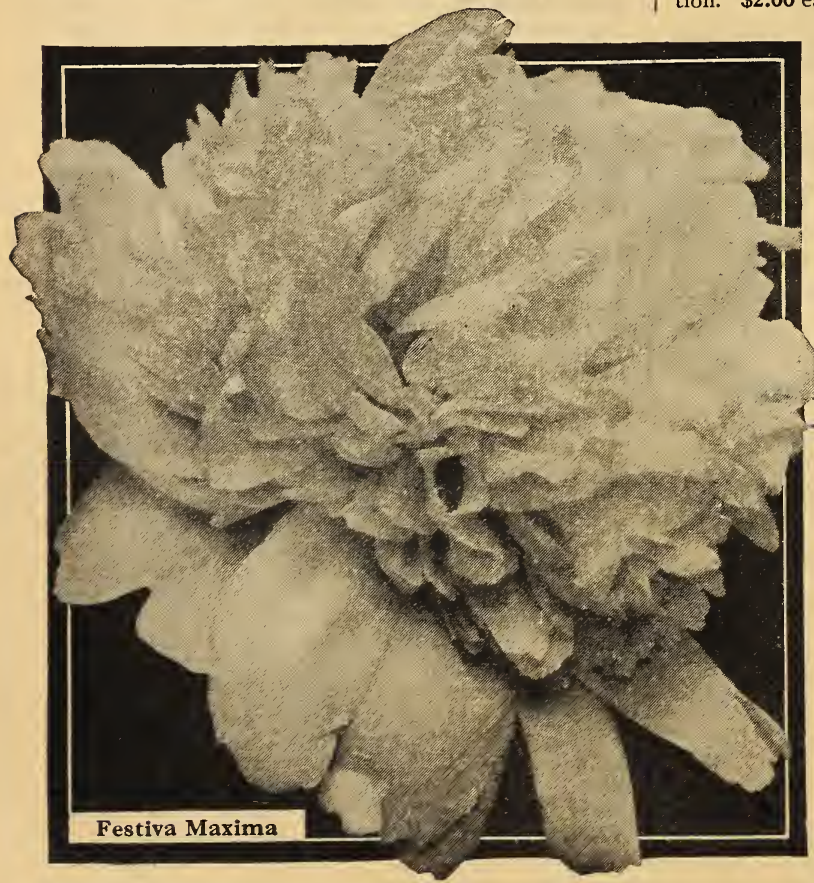

8728 Le Cygne $T$ his is a most remarkable Peony, and because it is a slow propagator it will always be rare. The full large blooms are thickly packed with small cup-shaped petals and they are smaller in the center than on the outside. The color is milky white, shading to pure white as the flowers open up fully. Free-blooming plants of medium height but most vigorous and of strong constitution. $\$ 9.50$ each 3 for $\$ 26.50$; 6 for $\$ 50.00 ; 12$ for $\$ 96.00$.

8730 Madame Ducel of bomb type, blooming during midseason, with broad guard petals, and the center being a huge ball of finely curved petals. Very large and strong. The color is a glistening lilac-pink with a touch of rosy mauve. Madame Ducel is a free-blooming and strong-growing Peony which makes a wonderful display with its double compact blooms. The showy majestic blooms are carried on fine long stems. $65 \not$ each; 3 for $\$ 1.75 ; 6$ for $\$ 3.30 ; 12$ for $\$ 6.00$.

\section{Four Glorious Peonies}

These contain the following four remarkable varieties: Baroness Schroeder, Karl Rosenfield, Sarah Bernhardt, and Germaine Bigot.

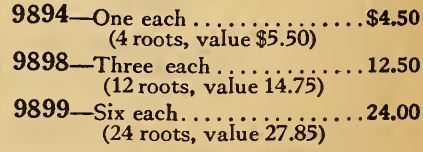


8727 Madame August Dessert An early midseason Peony with large cupshaped flowers of perfect form. The petals are of well-rounded shape. It is an extra fine freeblooming variety, of a rich and beautiful flesh tint, with just a touch of bright carmine enlivening the whole flower. The center of the blooms is marked with spots of bright crimson. Astrong grower and profuse bloomer. $\$ 1.00$ each; 3 for $\$ 2.70 ; 6$ for $\$ 5.25 ; 12$ for $\$ 10.00$.

8719 Milton Hill This has always been considered a great variety belonging to the late blooming class of Peonies. The petals are of exquisite texture which goes well with the beautiful shell-pink color of the blooms. It is a flower of magnificent size and excellent form, the petals being crowded together into a massive and majestic flower. It is a valuable variety. $\$ 4.50$ each; 3 for $\$ 12.00$; 6 for $\$ 23.00$; 12 for $\$ 45.00$.

8717 Mons. Jules Elie An early midseason bloomer belonging to the bomb type. Immense blooms crowded with exquisite petals into a globular, well-rounded flower. The color is a glossy lilac-pink shading to deep rose at the base. There is a glistening sheen overlying the whole flower, adding a brilliant touch to it. A wonderful and popular variety. $\$ 1.00$ each; 3 for $\$ 2.70 ; 6$ for $\$ 5.25 ; 12$ for $\$ 10.00$.

8716 Mons. Martin Cahuzac A semi-rose type Peony blooming during midseason. Truly a marvelous variety which has always been in great demand. The flowers are large and massive. They are well formed, with the petals crowded together into a full solid ball. The color is a rich deep maroon with a cast of garnet and a metallic black lustre. It will add a rich contrast to your collection. $\$ 3.25$ each; 3 for $\$ 9.00 ; 6$ for $\$ 17.50 ; 12$ for $\$ 34.00$.

8726 Primevere Blooms during midseason and produces magnificent trusses of fine bomb type blooms. Carried on tall strong stems are excellent solid flowers with broad sulphur-white outer petals and deep sulphur-yellow falls. This is considered by many the best yellow Peony in existence even though the color is quite light. A strong, vigorous variety, producing a wealth of flowers which are excellent for cutting even though they lack fragrance. $\$ 3.75$ each; 3 for $\$ 10.75 ; 6$ for $\$ 20.50 ; 12$ for $\$ 40.00$.

8718 Rubra Superba Brilliant deep crimson flowers borne very late in the season. A rose type, making a most magnificent show. The color is brilliant and intense and is much in demand, largely due to the fact that this is the best keeping Peony we have ever seen. The blooms are double, exquisitely fragrant, and excellent for both garden display and for cutting. Rubra Superba is a good, vigorous grower. $65 \notin$ each; 3 for $\$ 1.75 ; 6$ for $\$ 3.30 ; 12$ for $\$ 6.00$.

$\mathbf{8 7 2 3}$ Sarah Bernhardt There is no other Peony which makes such a strong growth as this variety, blooming during the late midseason. It belongs to the semi-rose type. Most gardeners who have seen this variety have become enthused about it and justly so. It is a huge, full, and double flower of unusual perfection. The petals are large, imbricated, twisted, and fimbriated. The color is a fine apple-blossom-pink. Each petal is tipped with silver-pink and bordered pure white. Agreeably fragrant. $\$ 1.75$ each; 3 for $\$ 4.75 ; 6$ for $\$ 9.00 ; 12$ for $\$ 17.00$.

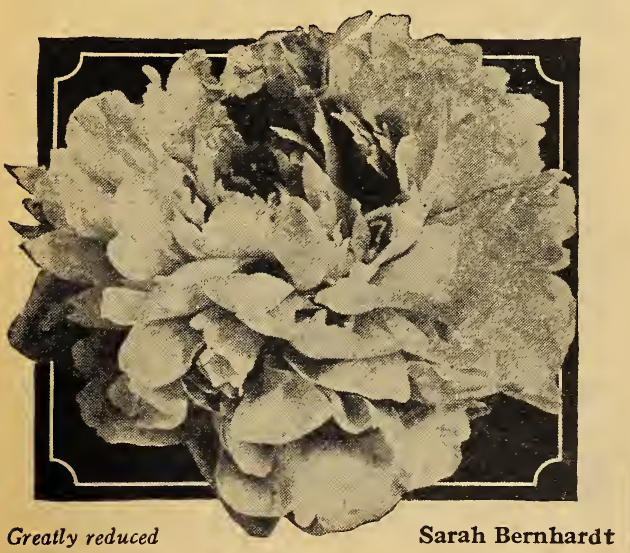

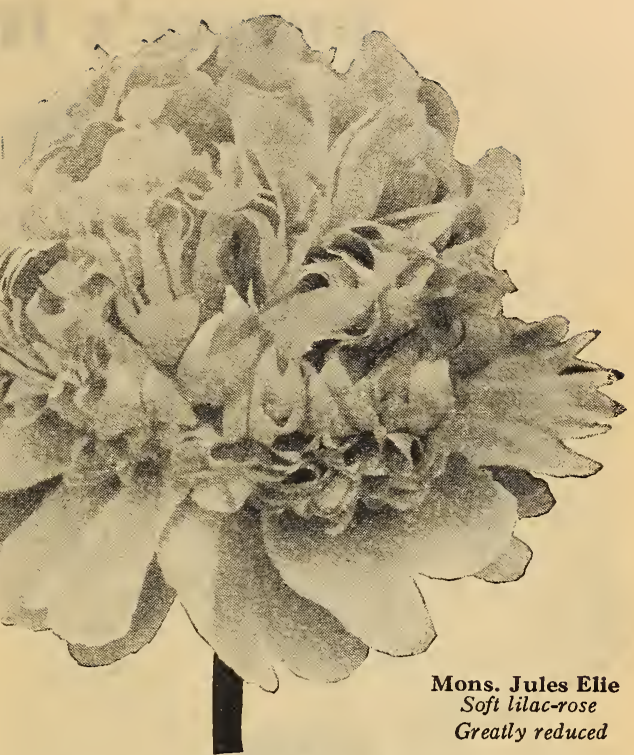

8725 Solange A splendid variety of remarkable size and outstanding beauty. The color is most unusual and rare. It is a blush-white with a salmon center, having a bright coffee-brown sheen with a metallic lustre. This makes a wonderful combination with the underlying salmon tone. Full, globular blooms with a crested tuft in the center. It is impossible to portray in words both the exquisite beauty of the flower and its color. $\$ 4.50$ each; 3 for $\$ 12.00$; 6 for $\$ 23.00 ; 12$ for $\$ 45.00$.

8710 Therese Many writers have expressed themselves in the most glorious terms about this wonderful midseason variety belonging to the rose type. The color is a rich satiny pink with a silky sheen. The flowers are enormous yet well shaped and of good proportions. Wherever it has been exhibited it has always been greatly admired. There are few other varieties that can compare with it in beauty. $\$ 4.50$ each; 3 for $\$ 12.00$; 6 for $\$ 23.00 ; 12$ for $\$ 45.00$.

8722 Umbellata Rosea Here is a good very early blooming rose type Peony at a price that makes it available for every garden. Those who want a large showy flower of an appealing color will find Umbellata Rosea very satisfactory. The guards are a lovely violet-rose, shading to amber-white in the center. A strong grower of upright habit, producing a wealth of fine blooms. $60 \varnothing$ each; 3 for $\$ 1.60 ; 6$ for $\$ 3.10 ; 12$ for $\$ 5.85$.

8724 Venus A fragrant and appealing variety belonging to the crown type. Flowers during midseason and produces a wealth of blooms. The color is delicate shellpink. Venus makes a strong stately plant and has again and again been chosen as one of the very best Peonies in existence. For cut-flowers it ranks most highly. $\$ 1.00$ each; 3 for $\$ 2.70$; 6 for $\$ 5.25 ; 12$ for $\$ 10.00$.

8729 Walter Faxon A rare and beautiful variety that will appeal to the collector who wishes something outstanding. It belongs to the semi-rose type and blooms during midseason. There is something elusive and fascinating about the delicate bright rosy pink flowers. Walter Faxon produces a wealth of well-shaped blooms carried upright on strong stems above the healthy green foliage. The color is refreshing yet delicate and of enchanting beauty. $\$ 5.50$ each; 3 for $\$ 15.50$; 6 for $\$ 30.00 ; 12$ for $\$ 58.50$.

\section{Six Standard Peonies}

An assortment of six showy free-flowering varieties at a price that is within reach of every gardener: Umbellata Rosea, Duchess de Nemours, Edulis Superba, Felix Crousse, Festiva Maxima, and Jeanne d'Arc.

9866 -One each ....... ( 6 roots, value $\$ 4.05$ ) $\$ 2.95$

9867 - Three each ..... (18 roots, value 10.85$) \quad 8.50$

9868-Six each........ (36 roots, value 20.95) 16.00 


\section{Burpee's Hardy Phlox}

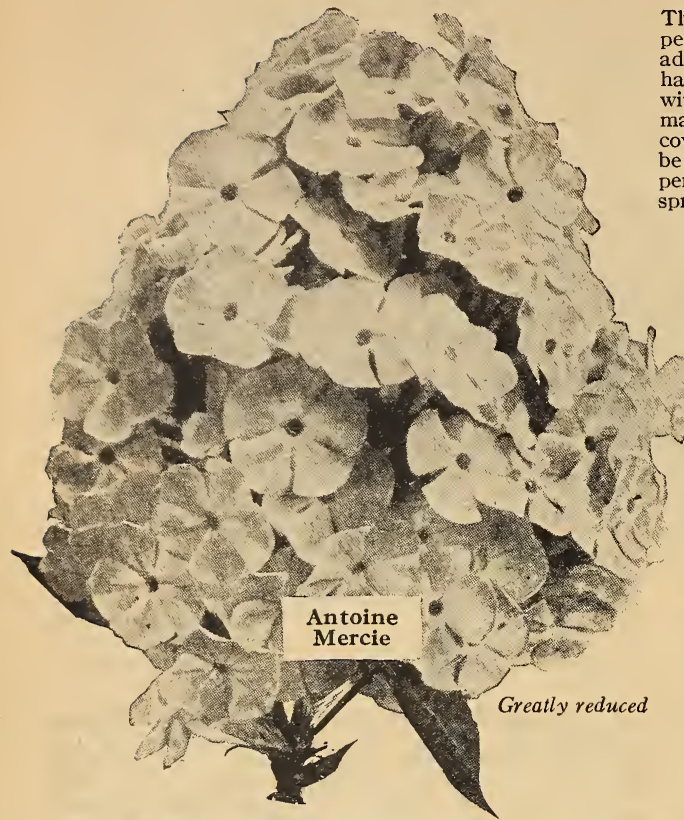

8750 Antoine Mercie A very showy perennial Phlox of a rather unusual color. The flowers are a bright and vivid shade of lilac with a contrasting pure white eye. This makes a strong growth and produces a profusion of large well-rounded flower-heads. It looks particularly attractive if planted in masses. $40 \notin$ each; 3 for $\$ 1.05$; 6 for $\$ 2.00 ; 12$ for $\$ 3.90 ; 25$ for $\$ 7.65 ; 50$ for $\$ 15.15$.

8751 Beacon A most magnificent flower of a brilliant cherry-red shade. Beacon is easily grown and blooms very profusely. The flower-heads are simply immense. They are carried on fine stems above the rich green foliage. This shade looks its best if seen in bright sunlight. The plants grow stronger every year and make a magnificent show, with their brightly colored blooms. $35 \notin$ each; 3 for $95 \notin$; 6 for $\$ 1.80 ; 12$ for $\$ 3.50 ; 25$ for $\$ 6.90 ; 50$ for $\$ 13.65$.

8756 B. Compte This is a very brilliant and showy variety of good strong growth and most profuse blooming. The individual flowers are large and combine into magnificent trusses of a brilliant French purple shade. This color is unusually bright and never fails to receive favorable attention. It looks best if planted in combination with some white variety. $35 \notin$ each; 3 for $95 \notin ; 6$ for $\$ 1.80 ; 12$ for $\$ 3.50 ; 25$ for $\$ 6.90 ; 50$ for $\$ 13.65$.

8764 Commander (Von Hindenburg) A newer variety of exceptional beauty. The large massive flowerheads are brilliant crimson-red with a pleasing and contrasting darker eye. Commander grows very freely and blooms profusely. The plants are sturdy and well-branched. They increase rapidly with every year. $40 \notin$ each; 3 for $\$ 1.05$. 6 for $\$ 2.00$; 12 for $\$ 3.90 ; 25$ for $\$ 7.65 ; 50$ for $\$ 15.15$.

8757 Elizabeth Campbell Of all Hardy Phlox, Elizabeth Campbell is perhaps the most popular on account of its outstanding color and other remarkable characteristics. The color of the flowers is a pleasing light salmon enlivened by a pinkish tint toward the center. Easily grown and exceptionally showy. 35 $\notin$ each; 3 for $95 \notin ; 6$ for $\$ 1.80$. 12 for $\$ 3.50 ; 25$ for $\$ 6.90 ; 50$ for $\$ 13.65$.

\section{Collections of Eight Hardy Phlox}

These eight varieties are all illustrated in color on the Back Cover : Thor, Europa, Widar, Rynstrom, Firebrand, Mrs. William Jenkins, Beacon, and Jules Sandeau.

9875-One each...... (8 roots, value $\$ 2.35) \$ 1.75$

9876-Three each...(24 roots, value 6.40$) \quad 4.75$

9877-Six each..... (48 roots, value 12.15$) \quad 8.75$
The Hardy Phlox belongs to our prettiest and most showy perennials. It is easily grown and thrives well even under adverse conditions of weather and soil. The plants are perfectly hardy and after once being established will become more showy with every year. The plants will spread with each season and make solid clumps, which during flowering time are literally covered with the handsome flower-heads. Hardy Phlox may be used to good advantage in front of shrubbery or among other perennials. The plants are a mass of blooms all during the spring and early summer.

8759 Europa Europa has always been a great favorite with many gardeners because of its exceptionally showy appearance. It is a strong grower, producing a mass of substantial upright stems crowned by large clusters of flowers. The blooms are white, with a fine light crimson eye in the center. This looks very well mixed in the perennial border or in the foreground of shrubbery. $30 \notin$ each; 3 for $85 \notin$; 6 for $\$ 1.60 ; 12$ for $\$ 3.05 ; 25$ for $\$ 6.00 ; 50$ for $\$ 11.90$.

8761 Ferdinand Cortez Those who prefer the richer and darker shades should give this excellent variety a trial. The color is an intense rich crimson shade with a brilliancy most appealing when seen in the bright sun. A vigorous grower which produces a mass of large bold flower-heads. The individual blooms are of good size, forming a dense round head. $35 \notin$ each; 3 for $95 \notin ; 6$ for $\$ 1.80$ 12 for $\$ 3.50$; 25 for $\$ 6.90$; 50 for $\$ 13.65$.

8768 Firebrand A most outstanding and rich variety introduced not so many years ago. It is, without question, the largest flowering Phlox in the orange-red section. The blooms are a lovely shade of glistening cerise shaded with vermilion and flamed with brilliant orange. A mass of these plants gives a picture of indescribable beauty. Of easy strong growth and entirely hardy. $35 \notin$ each; 3 for $95 \notin$; 6 for $\$ 1.80 ; 12$ for $\$ 3.50 ; 25$ for $\$ 6.90 ; 50$ for $\$ 13.65$.

8766 Jules Sandeau Jules Sandeau is grown extensively where a variety of dwarf habit is wanted and it fills this place admirably well. In size of the individual flowers and flower-heads and in free-blooming character it holds its own with the taller growing varieties. The color is a fine pure shade of bright pink. $30 \notin$ each; 3 for $85 \notin$; 6 for $\$ 1.60$; 12 for $\$ 3.05 ; 25$ for $\$ 6.00 ; 50$ for $\$ 11.90$.

8765 Mrs. Milly van Hoboken A very fine new variety which has quickly gained the popular favor. of many gardeners. It surely is an outstanding variety in many ways. The color of the blooms is bright shell-pink with a silver reverse and showing a varying suffusion of bright mauve. The lovely carmine eye adds to the pleasing effect of the flowers. $40 \notin$ each; 3 for $\$ 1.05$; 6 for $\$ 2.00$; 12 for $\$ 3.90 ; 25$ for $\$ 7.65 ; 50$ for $\$ 15.15$.

8774 Mrs. William Jenkins Here is a variety which enjoys as great popularity now as it did when first introduced. It forms magnificent plants, growing about 3 feet tall. Of strong growth with rich bright green foliage, surmounted by large well-rounded heads of snow-white blooms. It is by far the best white Phlox and blooms exceedingly early. $25 \notin$ each; 3 for $65 \notin ; 6$ for $\$ 1.25$; 12 for $\$ 2.40 ; 25$ for $\$ 4.65 ; 50$ for $\$ 9.15$.

8776 Rheinlander The beautiful carmine-pink flowers of this variety always attract attention. They are of large size, forming fine globular trusses carried against a background of rich green foliage. It is a free-blooming variety which makes a very large plant covered with flowerheads during the blooming season. $30 \notin$ each; 3 for $85 \notin$; 6 for $\$ 1.60$; 12 for $\$ 3.05 ; 25$ for $\$ 6.00 ; 50$ for $\$ 11.90$.

8778 Rynstrom An excellent variety which originated in Europe but has gained a strong foothold in America due to its many valuable points. The individual flowers are very large and they combine into heavy, massive trusses of a bright rose-pink shade. An exceptionally strong grower, free blooming, and of showy habit. $25 \notin$ each; 3 for $65 \notin$; 6 for $\$ 1.25 ; 12$ for $\$ 2.40 ; 25$ for $\$ 4.65 ; 50$ for $\$ 9.15$.

8784 Thor In this variety we have a fine combination of bright and silky salmon-pink with a deep crimson eye in the center. The color contrast is very outstanding and pleasing to the eye. Thor is worth growing not only because of its excellent color but also because of its outstanding habit of growth. $30 \notin$ each; 3 for $85 \notin$; 6 for $\$ 1.60 ; 12$ for $\$ 3.05$; 25 for $\$ 6.00 ; 50$ for $\$ 11.90$.

8792 Widar Widar is a popular variety. The plants make a strong and stocky growth. They are free-blooming and carry the flower-trusses on long strong stems well above the foliage. The individual blooms are large and well formed. They are placed closely together, making a solid truss or ball of flowers. The color of the blooms is a light rosy violet with a white center. $25 \notin$ each; 3 for $65 \notin$; 6 for $\$ 1.25 ; 12$ for $\$ 2.40 ; 25$ for $\$ 4.65 ; 50$ for $\$ 9.15$. 


\section{Spiraea or Astilbe}

These handsome perennial plants deserve to be grown by far more widely. They form neat compact bushes 2 to 3 feet tall. Spiraeas do best in a fairly rich soil and bloom profusely during the summer and fall. They can also be grown indoors during winter and early spring where they will flower in 10 to 14 weeks after planting.

8662 America The large and gracefuI panicles are a beautiful violet-blue color. A strong grower and profuse bloomer.

75 c each; 3 for $\$ 2.05 ; 6$ for $\$ 3.95 ; 12$ for $\$ 7.75$.

8664 Gladstone This is the very best white of all Hardy Spiraeas. Blooms freely. 75 each; 3 for $\$ 2.05$; 6 for $\$ 3.95$; 12 for $\$ 7.75$.

8666 Peach Blossom A handsome variety with delicate light pink flowers. 75 c each; 3 for $\$ 2.05$; 6 for $\$ 3.95 ; 12$ for $\$ 7.75$.

8669 Queen Alexandria Crowned with handsome rose-pink flower-spikes. 75 \& each; 3 for $\$ 2.05 ; 6$ for $\$ 3.95 ; 12$ for $\$ 7.75$.

8672 Rubens This is an outstanding variety of clear carmine color. $75 \&$ each; 3 for $\$ 2.05 ; 6$ for $\$ 3.95 ; 12$ for $\$ 7.75$.

Collection of
Five Hardy Spiraeas
9795 This collection contains one
each of the frve distinct varieties
offered above. Value $\$ 3.75, \quad \$ 3.00$
mailed, postpaid, for

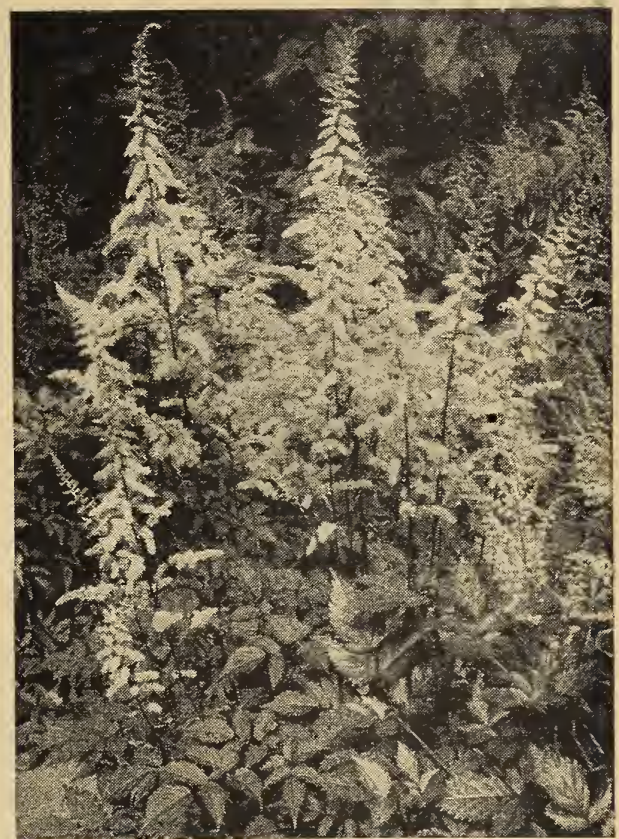

8674 Spiraea, Mixed This mixture includes the right proportions of the various fine colors of Spiraea offered on this page. We recommend it for mass planting in front of shrubbery or among perennials. 60 each; 3 for $\$ 1.60$; 6 for $\$ 3.05 ; 12$ for $\$ 5.95$.

\section{Hardy Asters}

Few perennial roots are as easily grown and make such a fine display, particularly when naturalized, as the Hardy Asters. Their culture is very easy and they will thrive in any ordinary garden soil. Hardy Asters produce a wealth of blooms during September and October.

8936 Elta Bright lilac-lavender with a contrasting tango-colored eye. The flowers are well rounded and close petaled. A very showy variety. 30 each; 3 for 85 ; 6 for $\$ 1.65$; 12 for $\$ 3.20 ; 25$ for $\$ 6.25 ; 50$ for $\$ 12.40$.

8937 St. Egwin Flowers throughout the fall. The blooms are a pleasing shade of soft rosy pink. Grows 3 to 4 feet tall. $30 \dot{c}$ each; 3 for 85 ; 6 for $\$ 1.65 ; 12$ for $\$ 3.20 ; 25$ for $\$ 6.25 ; 50$ for $\$ 12.40$.

8943 Mrs. Rayner This is the deepest red of all perennial Asters. It makes a magnificent display, particularly when planted in masses. Very fine grouped together in the perennial border or in the foreground of shrubbery.

35 c each; 3 for $\$ 1.00$; 6 for $\$ 1.95 ; 12$ for $\$ 3.80$; 25 for $\$ 7.50$; 50 for $\$ 14.90$.

\begin{abstract}
8940 Feltham Blue Light aniline-blue flowers borne on fine compact heads; $2 \mathrm{I} / 2$ feet tall. 25 c each; 3 for 70 c; 6 for $\$ 1.35 ; 12$ for $\$ 2.55$; 25 for $\$ 5.00$; 50 for $\$ 9.90$.
\end{abstract}

8944 Perry's White A mass of fine single white flowers shaded Iilac. Blooms from August till October; 4 feet tall. 30 e each; 3 for 85 ; 6 for $\$ 1.65 ; 12$ for $\$ 3.20 ; 25$ for $\$ 6.25 ; 50$ for $\$ 12.40$.

8951 Blue Gem Semi-double dark bue flowers during September and October. Grows 4 to 5 feet tall. 30 ć each; 3 for 85 c; 6 for $\$ 1.65$; 12 for $\$ 3.20 ; 25$ for $\$ 6.25 ; 50$ for $\$ 12.40$.

8938 Mixed A complete mixture of all the fine colors listed. 3 for $75 c ; 6$ for $\$ 1.40 ; 12$ for $\$ 2.65 ; 25$ for $\$ 5.15 ; 50$ for $\$ 10.15$.

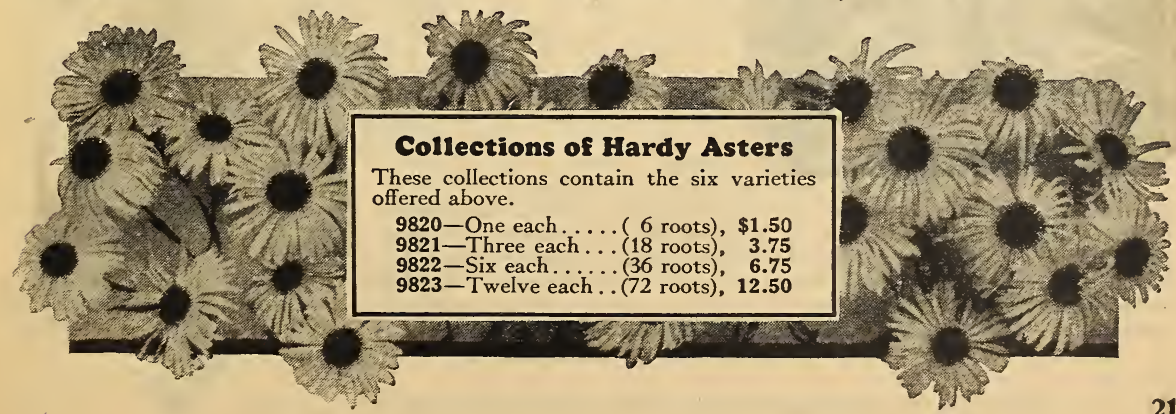



grown and the varieties we list are perfectly hardy. With every year they will increase in size and attractiveness. Lilies do best in a well-drained sandy soil which should be fairly rich. The plants need plenty of water during periods of drought. Plant the bulbs as early in the fall as they can be had. It is important to plant deeply. As a general rule, the top of the bulb should be located three times as deep as the greatest diameter of the bulb. The distance between the plants should be from 12 to 18 inches. To provide the necessary drainage dig the hole which is to hold the bulb and place the bulb at the bottom on a layer of sand, filling in fine sand aII around it until completely covered. On top of this is placed ordinary garden soil. Many bulbs are late maturing and cannot be shipped before November first. Where the ground is likely to freeze before the bulbs arrive, cover it with a mulch of straw, manure, or leaves several inches deep to keep the ground in condition for planting as soon as the bulbs are received. These late plantings are usually very successful.

8602 Bermuda Easter Lily (Harrisii) See illustration. The Bermuda Easter Lily is the strongest of all the longiflorum Lilies, which are commonly known as Japanese Easter Lilies. This variety is the one planted extensively for winter blooming and is forced in great quantities for Easter. The plants grow 4 feet tall, carrying from five to twenty Iarge, waxy white flowers on a single stem. The blooms have a delightfuI fragrance. The individual flowers measure 4 to 6 inches in length and are quite often tinged with green near the base. The anthers are yellow. Planted in the open, they make a sturdy growth and bloom during July and early August. Ready for delivery in September. $35 \mathrm{c}$ each; 3 for $95 \phi$; 6 for $\$ 1.80$; 12 for $\$ 3.50$.

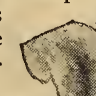

8614 Easter Lily (Formosum) This is quite similar to the Bermuda Easter Lily. However, it does not make as taIl a growth, but is better suited for outdoor planting in the garden. It is also known as Japanese Easter Lily and Trumpet Lily. The plants grow one to three feet in height and bear at the top a whorl of one to ten flowers. The blooms are 4 to 6 inches long and nearly as wide. The waxy white corolla is relieved by a greenish tinge at the base and by the bright yellow anthers. The plants bloom profusely during July and early August.

This fine Lily is entirely hardy if planted in a suitable location and the plants will increase in size and beauty with every year. It develops its fullest beauty if the bulbs are left undisturbed. Ready for delivery November 1st. $45 \&$ each; 3 for $\$ 1.20$; 6 for $\$ 2.30 ; 12$ for $\$ 4.50$.

\section{Golden Banded Lily of Japan} (Auratum) See illustration. This is also known as Golden-Rayed and The Queen of Lilies. It is a magnificent variety, with strong stems growing 3 to 6 feet in height. Each stem carries from two to fifteen flowers. The blooms are of enormous size, measuring 6 to 10 inches in diameter. They are delightfully fragrant. The petals are pure white, attractively spotted with bright crimson. There is a yellow band running along the mid-rib, extending the whole Iength of each
petal. It is this characteristic which
has given the flower its name, Golden Banded Lily. The deep red anthers add greatly to the

color contrast.
Even though it is a hardy variety it sometimes disappears two or three years after planting. However, it is of such outstanding beauty that it should be grown everywhere, even if replanting is necessary. Blooms during July and August.

Golden Banded Lily of Japan Ready for delivery Novem-

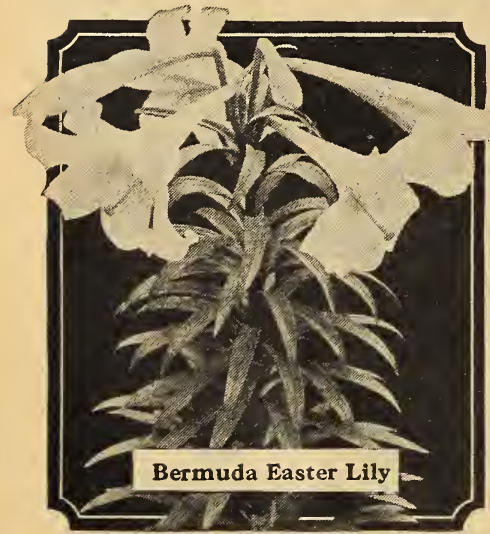

\section{Madonna Lily} (Candidum) See illustration. Some gardeners call this variety Annunciation Lily, Lent Lily, Bourbon Lily, or St. Joseph's Lily. The large number of common names is a sure sign of its great popularity among gardeners. The plants grow 2 to 4 feet tall and bear a large number of rich, deep green, narrow leaves all along the stems. The flowers measure 3 to 4 inches in length and are fully as wide. They are borne in clusters of from 3 to 20 at the top of each stem. They have a delightful fragrance. The blooms are waxy white and have yellow anthers. This is considered by many to be the Lily referred to in the Bible. It is of easy cultivation and does well in any soil or location, lasting almost indefinitely after once being established. For forcing it is unsurpassed. Planted outdoors it blooms during June and July. Ready for delivery in September. $30 \notin$ each; 3 for $85 \notin ; 6$ for $\$ 1.60 ; 12$ for $\$ 3.05$. ber 1 st. $35 \phi$ each; 3 for $95 \notin$; 6 for $\$ 1.80$; 12 for $\$ 3.50$.

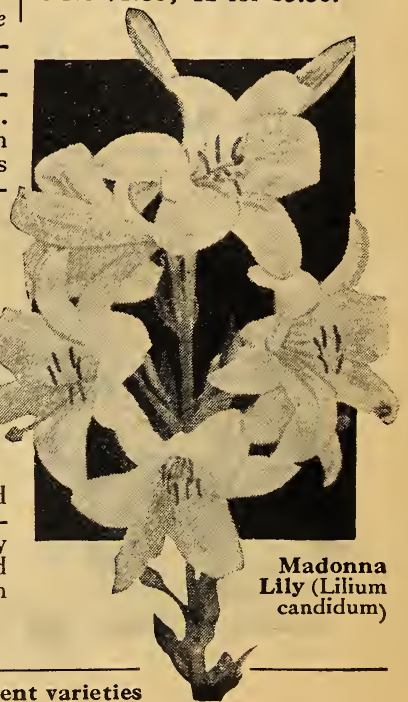


8631 Royal Lily (Lilium Regale) See illustration. This is one of the most beautiful of all Lilies. The blooms are borne in clusters and measure 4 to 6 inches in length. They have a sweet fragrance. The inside of the flowers is bright canary-yellow in the throat, shading to blush-white toward the edges. Quite of ten there is a pink suffusion throughout the whole flower. The outside is a waxy white with a purple midrib running through the center. Blooms profusely during JuIy and early August. Ready for delivery November $1.60 \mathrm{c}$ each; 3 for $\$ 1.60 ; 6$ for $\$ 3.05 ; 12$ for $\$ 5.95$; 25 for $\$ 11.75 ; 50$ for $\$ 23.40 ; 100$ for $\$ 46.50$.

\section{Turk's Cap Lily (Bate-} manniæ) An excellent Lily, native of Japan. Its hardiness, strong sturdy growth, andease of cultivation makeitone of themost desirable of all Lilies. Carried on a strong stem, 2 to 4 feet tall, is a magnificent cluster of flowers-sometimes as many as 12 blooms in a cluster. The individual blooms measure 3 to 5 inches in diameter. They are a pale orange-red or apricot, sometimes tinged with pink, but free from any spots or markings. 45 each; 3 for $\$ 1.20$; 6 for $\$ 2.30 ; 12$ for $\$ 4.50 ; 25$ for $\$ 8.90$.

\section{Canadian Lily} (Canadense) This is also known as Meadow Lily and Wild Yellow Lily. plantsgrow 2 to 5 feet tall, bearing from one to ten flowers on a single stem. The individual blooms are 2 to 3 inches long and they are nearly as wide. color is a bright orange-yellow, attractively spotted with purplish brown. The anthers are red. On account of its ease of cultivation and its gracefulness it is planted extensively by many gardeners. The blooming period falls from late June to early August. Ready for delivery November 1 . 25 $k$ each; 3 for $70 \notin ;$ 6 for $\$ 1.30$; 12 for $\$ 2.45$.
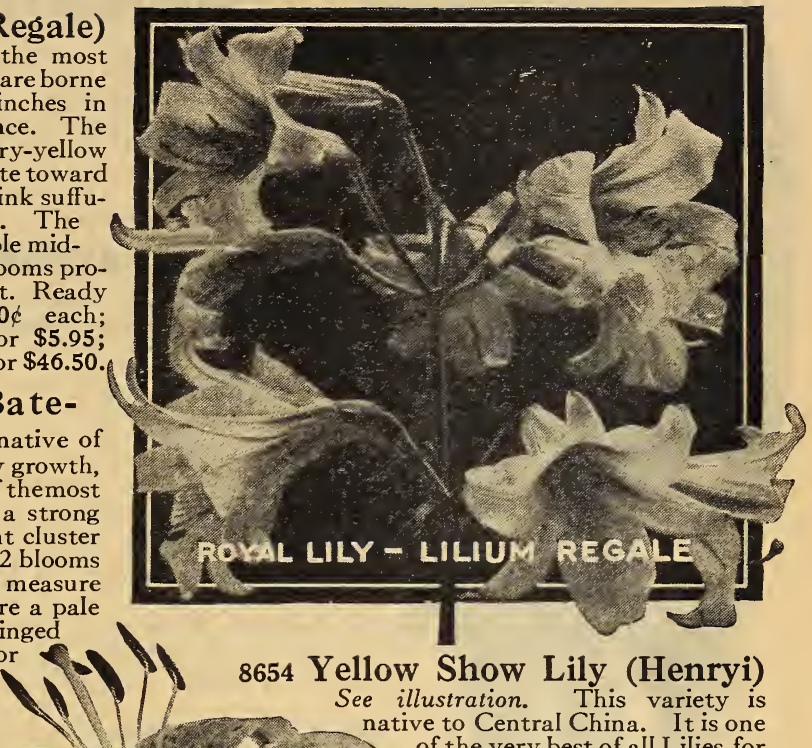
8654 Yellow Show Lily (Henryi) See illustration. This variety is native to Central China. It is one

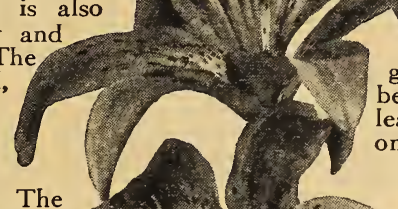

in almost any soil and situation. It is long-lived, hardy, and strong growing. The plants grow 4 to 8 feet tall, bearing a large number of long, narrow leaves. There are as many as 20 blooms on a stem.

The individual flowers measure 3 to 4 inches in diameter and they are a bright orange-yellow, spotted reddish brown and having a green band at the base of each petal. The anthers are bright orange-red. Blooms during August and September. Ready for delivery November $1.65 \dot{k}$ each; 3 for $\$ 1.75 ; 6$ for $\$ 3.35 ; 12$ for $\$ 6.55$.

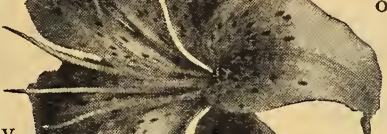
638 Swamp Lily (Superbum) This is also known as the American Turk's Cap Lily. The flowering plants are 3 to 8 feet tall, with as many as 40 flowers crowning each stem. The diameter of the individual flowers is 3 to 4 inches, and the color is a brilliant orange-scarlet, shaded yellow and

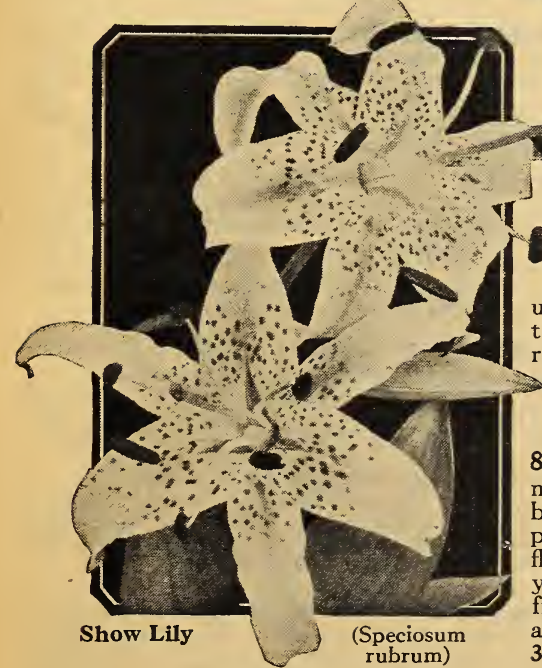

Yellow Show Lily spotted purplish brown at the base. The anthers are bright red. Blooms from late July to early September. Ready for delivery in October. 25\& each; 3 for 70 ; 6 for $\$ 1.30 ; 12$ for $\$ 2.45$

8634 Show Lily (Speciosum rubrum) See

illustration. A beautiful Lily for growing either in the garden or in pots. The flowers are borne in clusters at the top of a stem 2 to 4 feet in height. The individual blooms measure 4 to 6 inches in diameter. They are white, most attractively suffused with rose-pink in the center and spotted with rich mahogany-red. The base shows a green stripe and the anthers are red. Blooms profusely during August and September. Ready for delivery in October. 30 c each; 3 for 85 ; 6 for $\$ 1.60 ; 12$ for $\$ 3.05$.

8653 Yellow Japanese Lily (Hansonii) This is a most beautiful and outstanding variety for general cultivation, being permanent, very strong, robust, and easily grown. The plants grow 3 to 5 feet tall and each stem bears as many as 10 flowers. The blooms are most showy, with their bright golden yellow flowers, spotted purplish brown. They are slightly fragrant. The anthers are orange-red. Blooms during June and early July. Ready for delivery November 1. $65 \&$ each;

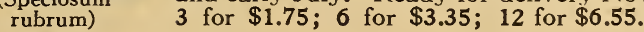




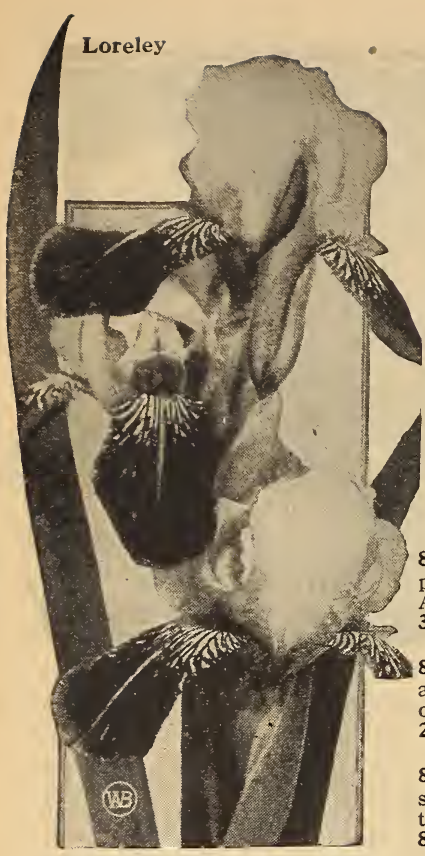

8500 Aurea This is also known under the name of California. The flowers are large and of perfect form, and are considered the finest pure yellow Iris in existence. Both the standard and the falls are a rich chrome-yellow color. Free blooming and very showy. $45 \notin$ each; 3 for $\$ 1.20$; 6 for $\$ 2.30 ; 12$ for $\$ 4.50 ; 50$ for $\$ 17.65 ; 100$ for $\$ 35.00$.

8501 Beethoven The combination of blue shades found in this variety enjoys great popularity. The standards are a lovely bright blue shade, forming a sharp harmonious contrast to the deep royal purple falls. The flowers are of excellent size. $25 \notin$ each; 3 for $65 \phi ; 6$ for $\$ 1.25 ; 12$ for $\$ 2.40 ; 50$ for $\$ 9.15 ; 100$ for $\$ 18.00$.

8505 Caprice A lovely soft rosy red with falls of a somewhat deeper shade. This grows quite vigorously and forms a good sized flower with an unusual a ppeal. Free flowering and highly recommended. $30 \notin$ each; 3 for $85 \phi$; 6 for $\$ 1.60 ; 12$ for $\$ 3.05 ; 50$ for $\$ 11.90 ; 100$ for $\$ 23.50$.

8566 Dawn A well-formed variety in which the color of the flowers is compared with the eastern sky just before the sun makes its appearance. It is a lovely, strong growing variety which will appeal to everyone. $40 \notin$ each; 3 for $\$ 1.05$; 6 for $\$ 2.00 ; 12$ for $\$ 3.90 ; 50$ for $\$ 15.15 ; 100$ for $\$ 30.00$.

8507 Eldorado A most striking flower, containing unusual and rare shadings. The standards are yellowish bronze shaded with bright glowing Heliotrope. The falls are rich bright purple with a cast of metallic bronze and coppery bronze veins. This is always admired. $25 \notin$ each; 3 for $65 \notin$; 6 for $\$ 1.25 ; 12$ for $\$ 2.40 ; 50$ for $\$ 9.15 ; 100$ for $\$ 18.00$.

8531 Fairy A truly fairy-like variety, with lovely white blooms delicately bordered with soft blue. The beauty of the flowers is enhanced by a soft suffusion of light blue cast over the entire flower. Grows 2 feet tall and blooms freely and continuously. $25 \notin$ each; 3 for $65 \notin ; 6$ for $\$ 1.25$; 12 for $\$ 2.40 ; 50$ for $\$ 9.15 ; 100$ for $\$ 18.00$.

8511 Florentina Alba This is a standard variety with large, perfectly formed white flowers produced in the greatest profusion from early in the season until late. Florentina Alba is outstanding. 25 ${ }^{2}$ each; 3 for $65 \phi$; 6 for $\$ 1.25 ; 12$ for $\$ 2.40 ; 50$ for $\$ 9.15 ; 100$ for $\$ 18.00$.

8532 Her Majesty An excellent variety. The flowers are extremely large and well formed. The color is a rare combination, the standards being a lovely rose-pink tone with the falls exhibiting crimson shades in varying degrees of intensity. $25 \notin$ each; 3 for $65 \notin ; 6$ for $\$ 1.25$; 12 for $\$ 2.40 ; 50$ for $\$ 9.15 ; 100$ for $\$ 18.00$.
8513 Isolene The standards are a dusty lavender attractively marked with dull bronze. The falls are light purple with a sheen of bronze and golden brown veins. These shades combine into a most unusual and rare effect. A handsome flower of very fine size and great appeal. $35 \%$ each; 3 for $95 \phi ; 6$ for $\$ 1.80 ; 12$ for $\$ 3.50 ; 50$ for $\$ 13.65$; 100 for $\$ 27.00$.

8510 Jeanne d'Arc A lovely flower with beautiful white standards and falls. The edges of the blooms are thickly penciled and marked with a lovely shade of light blue. A well-shaped, large flower which will give variety to any planting or bouquet. $30 \not$ each; 3 for $85 \not \varnothing ; 6$ for $\$ 1.60$; 12 for $\$ 3.05 ; 50$ for $\$ 11.90 ; 100$ for $\$ 23.50$.

8569 Lent A. Williamson The standards are broad and exhibit a lovely shade of Campanula violet. The falls are very large, of velvety purple color, with a golden yellow beard. $75 \notin$ each; 3 for $\$ 2.05$; 6 for $\$ 3.95$; 12 for $\$ 7.75 ; 50$ for $\$ 30.65 ; 100$ for $\$ 61.00$.

8512 Lohengrin This bright variety is almost a self color, both the standards and the falls being a uniform shade of Cattleya rose. Lohengrin is an excellent variety, carrying its massive blooms on extra long and strong stems. We can highly recommend this variety. $30 \notin$ each; 3 for $85 \notin$; 6 for $\$ 1.60 ; 12$ for $\$ 3.05 ; 50$ for $\$ 11.90 ; 100$ for $\$ 23.50$.

8514 Loreley $T$ his is another outstanding Bearded Iris which really belongs in every assortment. The flowers are large and well shaped. The standards are a lovely light yellow shade, forming a charming contrast to the ultramarine-blue falls. A border of cream around the falls adds greatly to the general effect. $25 \not$ each; 3 for $65 \phi ; 6$ for $\$ 1.25 ; 12$ for $\$ 2.40 ; 50$ for $\$ 9.15 ; 100$ for $\$ 18.00$.

8517 Madame Chereau This grows about 32 inches tall and has elegant large flowers exhibiting a most exquisite frilled border of clear blue against the snow-white petals. A dainty color combination. $25 \notin$ each; 3 for $65 \propto$; 6 for $\$ 1.25 ; 12$ for $\$ 2.40 ; 50$ for $\$ 9.15 ; 100$ for $\$ 18.00$.

8519 Midnight One of the darkest Bearded Iris we have ever seen. For this reason it has been named Midnight. The color is a bronzy blue shade not unlike the sky as seen during a moonless night. $35 \not$ each; 3 for $95 \varnothing ; 6$ for $\$ 1.80$; 12 for $\$ 3.50 ; 50$ for $\$ 13.65 ; 100$ for $\$ 27.00$.

8520 Monsignor The standards are crimson attractively dotted with bright lavender. The inner petals are ivory-white. Contrasting with this are the rich crimson falls with their bright lavender border. $30 \notin$ each; 3 for $85 \propto$; 6 for $\$ 1.60 ; 12$ for $\$ 3.05 ; 50$ for $\$ 11.90 ; 100$ for $\$ 23.50$. 
8509 Mother of Pearl A most magnificent Iris which originated in this country. It is impossible to describe its exquisite beauty-an iridescent pearl-like tint of light blue shaded with mauve. $75 \notin$ each; 3 for $\$ 2.05 ; 6$ for $\$ 3.95 ; 12$ for $\$ 7.75 ; 50$ for $\$ 30.65 ; 100$ for $\$ 61.00$.

8533 Nibelungen The standards are a quaint shade of olive-green and the falls are a combination of yellow, purple, and white. A freeblooming and most attractive variety, with large flowers. $25 \notin$ each; 3 for $65 \dot{\phi} ; 6$ for $\$ 1.25 ; 12$ for $\$ 2.40 ; 50$ for $\$ 9.15 ; 100$ for $\$ 18.00$.

8568 Opera A rich red-purple-a color which enlivens any assortment. The blooms are well shaped and make a very attractive show. Blooms freely and carries its excellent flowers on fine long stems. $85 \not$ each; 3 for $\$ 2.35 ; 6$ for $\$ 4.60 ; 12$ for $\$ 9.05 ; 50$ for $\$ 35.90 ; 100$ for $\$ 71.50$.

8522 Pallida Dalmatica The king of all Iris, with uniformly large flowers borne on stems 4 feet tall. The standards are an exquisite shade of soft lavender and the falls are deep lavender. $35 \not$ each; 3 for $95 \notin ; 6$ for $\$ 1.80 ; 12$ for $\$ 3.50 ; 50$ for $\$ 13.65 ; 100$ for $\$ 27.00$.

8521 Parisensis The fine blue standards harmonize well with the deeper blue falls. The flowers are large and borne very early. This lovely combination of blue shades has always enjoyed great popularity. 35 each; 3 for $95 \not ; 6$ for $\$ 1.80 ; 12$ for $\$ 3.50 ; 50$ for $\$ 13.65 ; 100$ for $\$ 27.00$.

8523 Prospero This is one of the tallest of all Iris. The standards are lavender-blue and the falls are a deep red-purple with bronzy brown markings and an orange beard. It is a most outstanding new variety. $\$ 1.50$ each; 3 for $\$ 4.00 ; 6$ for $\$ 7.60 ; 12$ for $\$ 14.50$.

8524 Queen of the May These lovely soft rosy lilac blooms are indeed delightful. They are large, well formed, and of exquisite texture. Blooms freely and is excellent for cutting. $25 \notin$ each; 3 for $65 \phi$; 6 for $\$ 1.25 ; 12$ for $\$ 2.40 ; 50$ for $\$ 9.15 ; 100$ for $\$ 18.00$.

8530 Sherwin Wright A vigorous variety of excellent habit, bearing very showy medium-sized blooms of a pure golden yellow color. Particularly fine in masses. $30 \notin$ each; 3 for $85 \notin ; 6$ for $\$ 1.60 ; 12$ for $\$ 3.05 ; 50$ for $\$ 11.90 ; 100$ for $\$ 23.50$.

8527 Violacea Grandiffora A fine clear violet-blue variety, growing 3 feet tall and blooming very early. $30 \notin$ each; 3 for $85 \not$; 6 for $\$ 1.60 ; 12$ for $\$ 3.05 ; 50$ for $\$ 11.90 ; 100$ for $\$ 23.50$.

8529 Bearded Iris, Mixed Our mixture includes a complete range of colors and will give a fine display, particularly if planted in quantity. 6 for $50 \not ; 12$ for $90 \not<; 50$ for $\$ 3.35 ; 100$ for $\$ 6.50$.

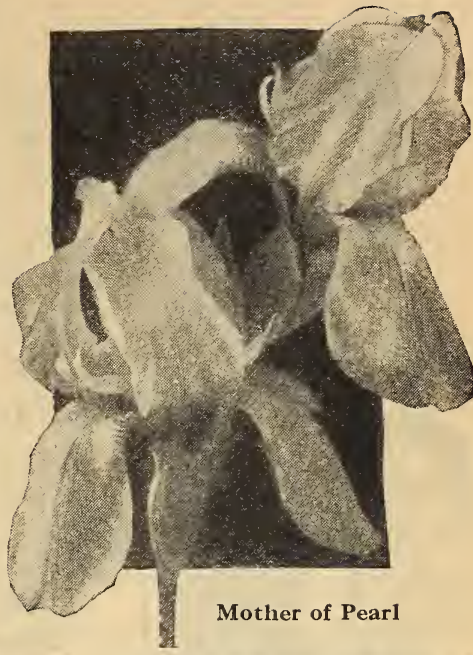

Eight Standard Iris

Aurea, Albert Victor, Beethoven Florentina Alba, Her Majesty Loreley, Madame Chereau, and Parisensis.

9860-One each (8 roots, value $\$ 2.30)$

9861-Three each (24 roots, value 6.05$)$

9862-Six each (48 roots, value 11.60 )

9863-Twelve each 14.00 96 roots, value 22.40 )

\section{JAPANESE IRIS}

The Japanese Iris enjoy great popularity because of their exceptional showiness and ease with which they are grown. They are entirely hardy and do best if planted in soil which is fairly moist and cool. For that reason they are used extensively for planting in masses along streams or ponds where they will quickly naturalize and multiply. The richly colored and showy blooms are borne during June and July.

8538 Azure A fine double variety with immense mauveblue flowers showing a darker halo around the yellow blotch at the base. A glorious variety, with well-expanded massiveblooms carried on fine long stems. Grows freely and makes a wonderful show. $40 \not$ each; 3 for $\$ 1.05 ; 6$ for $\$ 2.00 ; 12$ for $\$ 3.90$.

8550 Catherine Parry A new double variety of a fine blue shade overlaid with rich rosy red. The high tufts in the center are almost triple. Very outstanding in every way and blooming profusely. $50 \notin$ each; 3 for $\$ 1.30 ; 6$ for $\$ 2.50 ; 12$ for $\$ 4.90$.

8537 Gold Bound This is another very popular double Japanese Iris with pure white flowers of exceptional size, having a gold bounded center. The plants are of sturdy growth and bloom profusely. $45 \not$ each; 3 for $\$ 1.20$; 6 for $\$ 2.30 ; 12$ for $\$ 4.50$.

8549 Indo Large expanded single blooms with wavy petals of largest size. The color is rich dark blue showing a few slight veins. The center is marked with a yellow blotch of unusual brightness. 40 \& each; 3 for $\$ 1.05 ; 6$ for $\$ 2.00 ; 12$ for $\$ 3.90$.

8543 Pyramid The rich violet-purple flowers are double and show beautiful white veins in the center of each petal. The contrast is very attractive. Easily grown and blooming prof usely on fine long stems. $40 \not$ each; 3 for $\$ 1.05 ; 6$ for $\$ 2.00 ; 12$ for $\$ 3.90$.

8544 Red Riding Hood An unusual shade combined with a fine single flower. The color is Amaranth-pink veined and suffused with white. This never fails to attract attention. $35 \not$ each; 3 for $95 \not ; 6$ for $\$ 1.80 ; 12$ for $\$ 3.50$.

8548 Seedlings of Japanese Iris We consider this the finest mixture of Japanese Iris that has ever been offered. It contains a large number of varieties and some very fine seedlings which have never been introduced. 3 for $40 \phi ; 6$ for $75 \notin$; 12 for $\$ 1.40 ; 25$ for $\$ 2.75 ; 50$ for $\$ 5.35 ; 100$ for $\$ 10.50$.

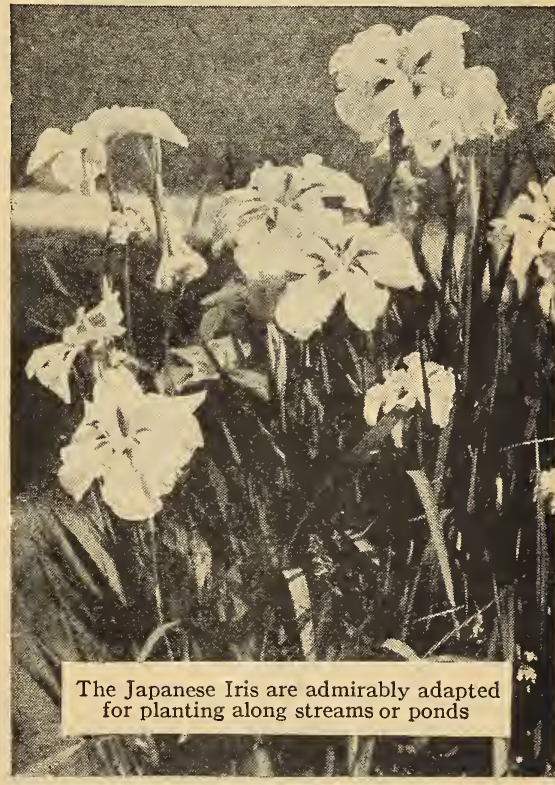

Collections of Japanese Iris Contain the six named varieties

9854 -One each . . ( 6 roots, value $\$ 2.50) \$ 1.75$

9855-Threeeach (18 roots, value 6.60 ) 4.75

9856-Six each ...(36 roots, value 12.60$) \quad 8.75$ 


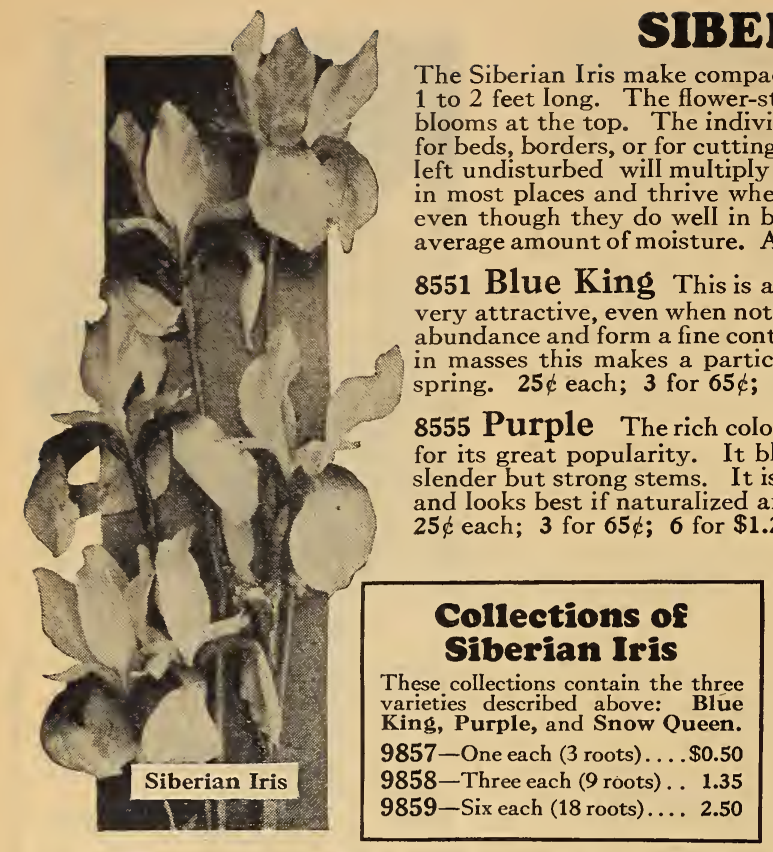

\section{SIBERIAN IRIS}

compact plants with dark green leaves which are 1 to 2 feet long. The flower-stems are slender and bear smaIl clusters of 作 r beds, borders, or for cutting. The Siberian Iris are easily grown and if chery rapidly. They are easily naturalized 列 en though they do well in beds or borders where they receive just an erage amount of moisture. As cut flowers they last a long time in water. in bloom. The flowers are borne in great particularly fine display during a few weeks of 8555 Purple The rich color of this Siberian Iris is mainly responsible for its great popularity. It blooms freely, with graceful flowers held on 列 nd looks best if naturalized among shrubbery or other perennial plants. ; 12 for $\$ 2.40$; 50 for $\$ 9.15$.

8559 Snow Queen Snow-white flowers borne in clusters of from 5 to 8 blooms on graceful slender stems. It is perfectly hardy everywhere. $25 \notin$ each; 3 for $65 \notin$; 6 for $\$ 1.25 ; 12$ for $\$ 2.40$; 50 for $\$ 9.15$.

8560 Siberian Iris, Mixed For mass planting this mixture will give the best effect. It contains the three different colors described above. It makes its best showing if planted liberally. 3 for $45 \%$; 6 for $80 \phi ; 12$ for $\$ 1.55 ; 50$ for $\$ 5.85$.

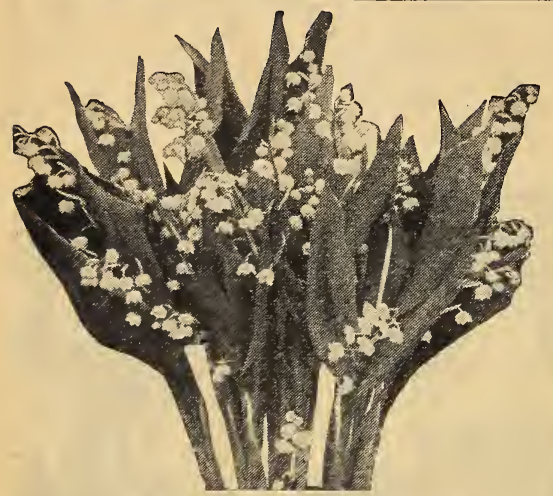

Anemone

8909 St. Brigid This mixture of beautiful Anemones contains a remarkable range of fine colors, including pink, rose, purple, Iavender, violet, scarlet, crimson, and many intermediate shades.

St. Brigid Anemones are easily grown. They bloom profusely from early March until May. Autumn is the right time for planting, placing the bulbs from 2 to 3 inches deep, and from 5 to 6 inches apart. It is necessary to firm the soil around the bulbs in order to get a satisfactory start. Where the weather does not drop below zero, no special shelter will be needed, but during severe weather a cover of straw or strawy manure is needed. For winter blooming in the house treat the bulbs as you would Hyacinths or Tulips.

St. Brigid Anemones grow 6 to 12 inches tall, each stem carrying a large single, semi-double, or double flower, measuring nearly 2 inches in diameter. 3 for $25 k$; 6 for $45 \phi ; 12$ for $85 \phi ; 50$ for $\$ 3.10 ; 100$ for $\$ 6.00$.

\section{Lily-of-the-Valley}

Few flowers are as well known and as much appreciated as the Lily-of-the-Valley. After once being planted in a suitable place they will increase in number and will produce their graceful and sweetly scented blooms every spring for an almost indefinite time.

We offer strong, freld-grown clumps which must not beconfused with the Lily-of-the-Valley pips that are used for forcing by florists. These clumps are intended for garden growing and will give immediate effect. $55 \&$ each; 3 for $\$ 1.45$; 6 for $\$ 2.80 ; 12$ for $\$ 5.50 ; 25$ for $\$ 10.90$.

All bulbs, roots, and seeds offered in this catalog will be delivered free either by parcel post or by express anywhere in the United States and its possessions, except where stated otherwise. We will send them to you by parcel post or express prepaid, whichever way seems best to us. To our Canadian and foreign customers we prepay the forwarding charges, but the customer pays the custom charges upon delivery.

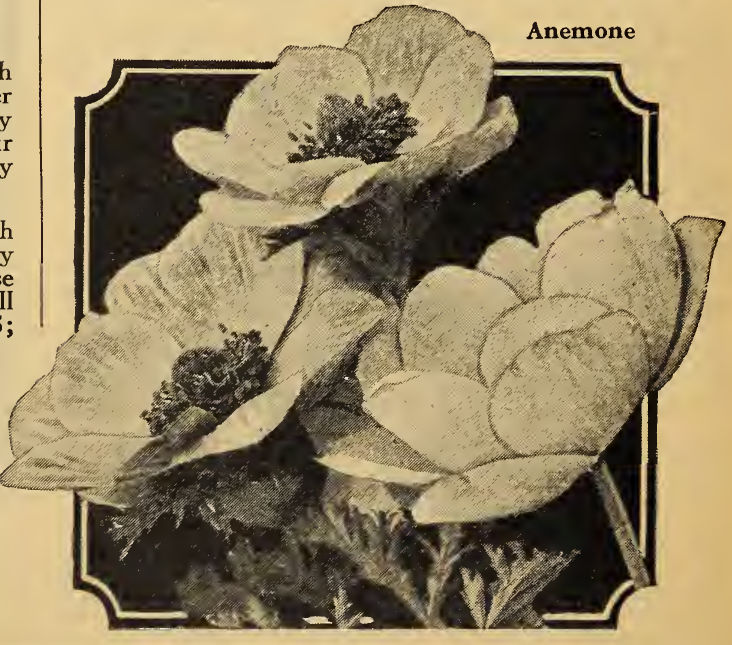


Outdoors: Hardly any other flower is so well adapted for naturalizing in the lawn or the meadow as the Crocus. The graceful form of the bright flowers when they bashfully lift their heads just as if to peep and see if anyone else is out yet makes the Crocus one of the loveliest of all spring-flowering bulbs.

Crocuses look best when planted in masses either in the lawn, among shrubbery, in the woodland, or in beds or borders. They bloom early and will have finished flowering before the grass is ready for the first cutting, to come up again early the following spring. When the bulbs are planted, they should be covered with about 2 inches of fine soil. They will Iast almost indefinitely.

In the house: It is easy to raise fine Crocus indoors during the winter. The bulbs may be planted in shallow pans, pots, or boxes filled with any good garden soil. They should be planted closely together, with the bulbs almost touching one another, covering them so that just the very tops of the bulbs show above the surface. Water the pots or pans thoroughly before placing them in an airy, cool but frostproof cellar and where mice cannot reach them. In three to five weeks' time the bulbs will have made a Iarge number of fine roots and they are then ready to go in a bright, sunny window, where they will bloom profusely. The room where the bulbs are placed to flower should be reasonably cool.

\section{All Bulbs offered in this catalog sent POSTPAID or EXPRESS PAID}

9504 Baron Brunow A very fine deep purple; the best one in this color. The flowers are of largest size. 6 for $25 \phi$; 12 for 40 c; 50 for $\$ 1.45 ; 100$ for $\$ 2.75 ; 1000$ for $\$ 25.00$.

9515 Golden Yellow A particularly fine variety with intense golden yellow flowers of Iarge size and fine shape. The most outstanding yellow. In mass-planting Golden Yellow gives a particularly fine effect, and there is none better for winterblooming in pots. It is a hardy and free-flowering variety. 6 for $25 \xi ; 12$ for $40 \xi ; 50$ for $\$ 1.45 ; 100$ for $\$ 2.75 ; 1000$ for $\$ 25.00$.

9523 Mont Blanc Purest white, with attractive Iarge, orange anthers. The texture of the petals is white and wax-like, and forms a sharp contrast against the rich green foliage.

6 for $25 \phi ; 12$ for 40 ; $; 50$ for $\$ 1.45 ; 100$ for $\$ 2.75 ; 1000$ for $\$ 25.00$.

9526 Pallas The bicolor varieties like Pallas are most attractive, especially if grown in shallow bulb pans for early indoor blooming. Pallas has Iarge well-developed blooms with a white ground striped and splashed with a lovely lilac shade. The rich orange anthers form a sharp but pleasing contrast.

6 for 25 ; 12 for 40 ; 50 for $\$ 1.45 ; 100$ for $\$ 2.75 ; 1000$ for $\$ 25.00$.

9533 Sir Walter Scott White, striped with pale lilac. It is the delicate combination of the soft lilac upon the waxy white background which accounts for the popularity of this variety. 6 for $25 \xi ; 12$ for $40 \xi ; 50$ for $\$ 1.45 ; 100$ for $\$ 2.75 ; 1000$ for $\$ 25.00$.

9535 Purpurea Grandiflora This is a most distinctive variety of strong sturdy growth. The flowers are remarkably large. They are easily forced and come into bloom very early. The color of the flowers is a bright and glowing purple.

6 for 25 ; 12 for 40 ; $; 0$ for $\$ 1.45 ; 100$ for $\$ 2.75 ; 1000$ for $\$ 25.00$.

9538 Blue and Purple Shades This is mixture comprising various shades of blue and purple Crocus. Gives a fine effect, particularly when naturalized in masses. 6 for $20 \notin ; 12$ for $35 \dot{c}$; 50 for $\$ 1.05 ; 100$ for $\$ 1.80 ; 500$ for $\$ 8.50 ; 1000$ for $\$ 16.00$.

9539 Striped, Mixed Various striped varieties of different colors on a white or softly tinted background. 6 for 20 ; 12 for 35 \&; 50 for $\$ 1.05 ; 100$ for $\$ 1.80 ; 500$ for $\$ 8.50 ; 1000$ for $\$ 16.00$.

9540 White, Mixed This mixture includes a number of varieties, all of which have white flowers. 6 for $20 \phi ; 12$ for $35 \phi$; 50 for $\$ 1.05 ; 100$ for $\$ 1.80 ; 500$ for $\$ 8.50 ; 1000$ for $\$ 16.00$.

9541 Yellow Shades This mixture includes a number of light and rich yellow shades which will make an excellent display planted in masses. 6 for 20 c; 12 for $35 \xi ; 50$ for $\$ 1.05$; 100 for $\$ 1.80 ; 500$ for $\$ 8.50 ; 1000$ for $\$ 16.00$.

9542 Fine Mixed Crocus A magnificent and complete mixture of all the finest varieties. Plant them in masses of a hundred

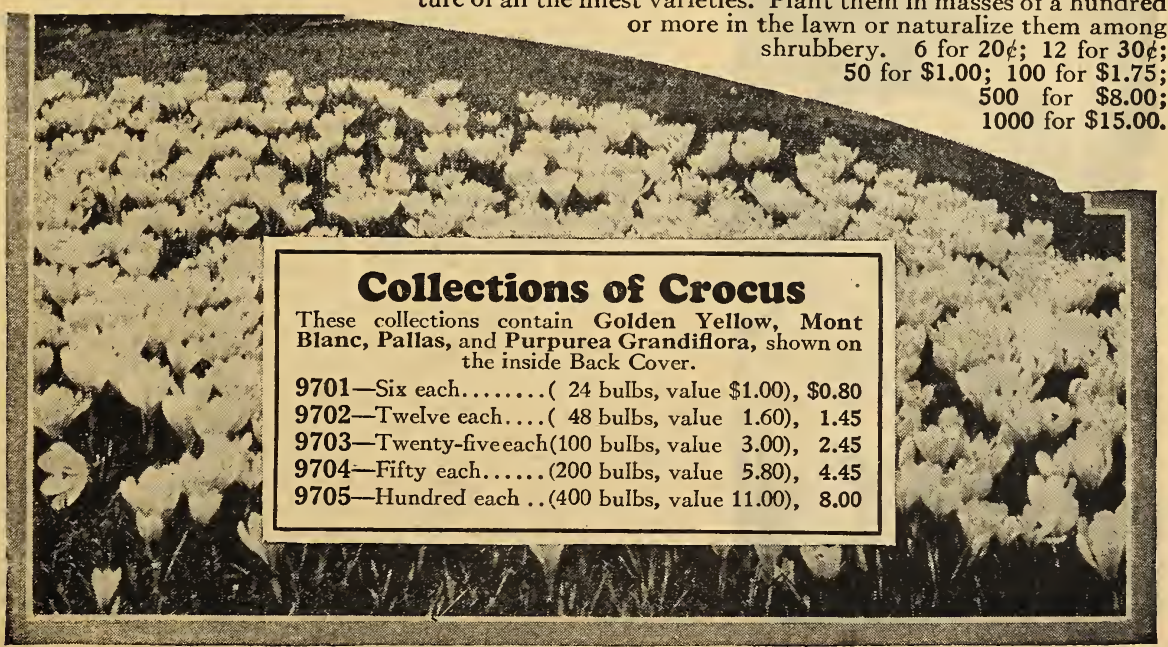




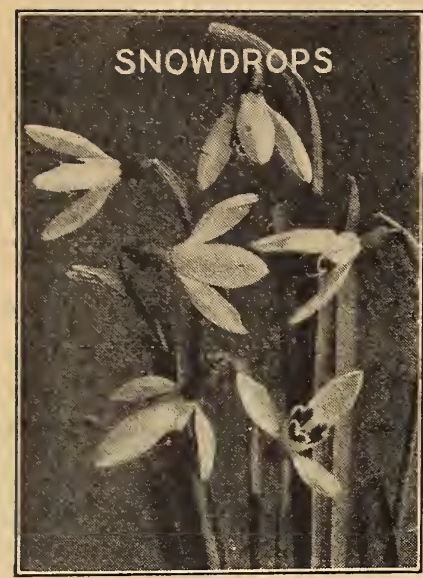

Snowdrops are so easily grown that no garden is complete without them. They are the first flowers of spring
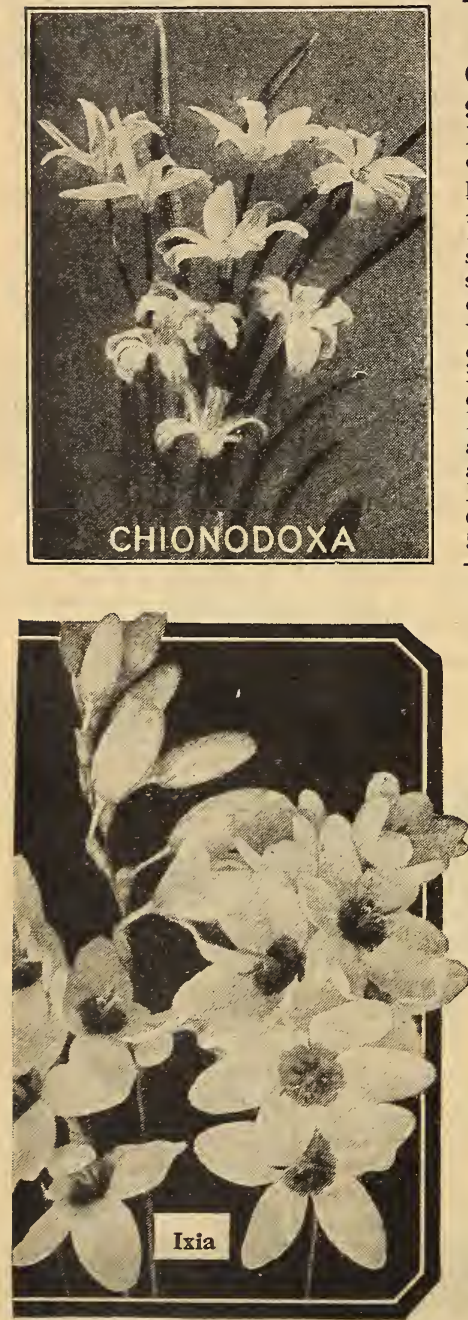

(Galanthus nivalis) Who does not know Snowdrops? Hardly any poem ever written about spring passes them by without heralding them as the first messengers of spring. They are the earliest of all spring blooming bulbs and do well in any kind of garden soil. For naturalizing among shrubbery or in the perennial border they are superb. Where the ground is somewhat sheltered by a house or a wall the flowers will come through the ground as early as February, long before all snow has gone. By making plantings in locations of different exposures, it is easy to have a succession of blooms for two to three months every year. Usually the flowers begin to open up about two weeks before the first Crocuses.

The bulbs do best if planted in masses in a cool, moist, and shady place. Under such conditions they will increase rapidly with every year. Yet Snowdrops will make a fine show in almost any kind of soil and they can stand harder treatment than most other bulbs.

The bulbs should be planted as early in the fall as they can be had. In planting the bulbs cover them with an inch or two of fine soil and set them from three to four inches apart. Early every spring the bulbs will send forth their slender stems, each holdling the gracefully drooping white flowers which are heralded as the first messengers of spring. 6 for $35 \xi ; 12$ for $60 \xi$; 50 for $\$ 2.10 ; 100$ for $\$ 4.00 ; 500$ for $\$ 24.00$.

\section{Chionodora Glory of the Snow}

9480 Luciliae A fine bulbous perennial for the open ground and also largely planted in pots for winter blooming in the house. Any kind of well-drained garden soil will give wonderful results. The attractive flowers are more or less deeply tipped with blue at the ends of the petals. Luciliae is the most showy of all the early spring flowering bulbs. Plant three inches deep and as close as one inch apart and they will bloom during March and April. 3 for $19 \dot{c}$;

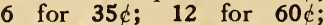
50 for $\$ 2.10 ; 100$ for $\$ 4.00$.

\section{Ixia 9488 Mixed}

A lovely spring flowering bulb which, however, is not always hardy north of Washington, even though it has come through the winter at various times when grown on Long Island and Massachusetts. For indoor culture plant 6 to 8 bulbs in a flower-pot filled with a good porous garden Ioam containing some leaf-mold and clean sand. Cover the tops with one inch of fine soil and place in a cool, dark spot where the temperature hovers around 45 degrees F. Water sparingly until leaf growth begins and then place in a sunny window but keep them at about 50 degrees $F$. When in full bloom give plenty of water. Our mixture contains pink, rose, crimson, orange, yellow, white, etc. 6 for $30 \xi ; 12$ for $50 \notin ; 50$ for $\$ 1.85 ; 100$ for $\$ 3.50$.

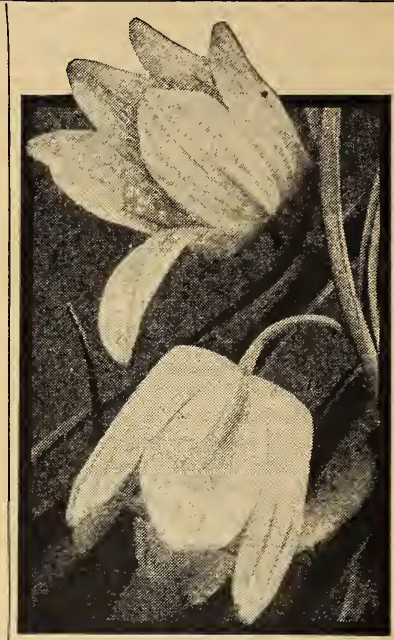

\section{Fritillaria}

\section{Mixed (Snake's Head)}

These are comparatively little known, but deserve to be grown more widely. They are perfectly hardy and excellent for planting among shrubbery or in the perennial border. Along streams and where the ground is shaded they do particularly well. The bell-shaped flowers are curiously marked, not unlike the scales on a snake's head. They come in various shades and combinations of colors. There are very bright purple and bronze tints, also fine white ones, but all of them are marked with contrasting colors, including green. After they have once become established they will not only last for many years but will multiply quite rapidly Plant the bulbs about 4 to 5 inches deep. 6 for

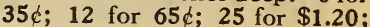
100 for $\$ 4.50$. 


\section{Bulbs for Winter-Flowering in the House}

The bulbs listed on this page are all tender and cannot be planted outdoors where freezing weather occurs. They are, however, excellent for growing in the house or conservatory. Most of the hardy bulbs are a!so easily raised in the house for winter blooming, such as: Tulips, Hyacinths, Narcissus, Scilla, Grape Hyacinths, Spiraea, Lilies, Crocus, Snowdrops, Ixia, and Chionodoxa." Write for a free copy of the Burpee leaflet, "Bulbs for Winter and Spring Blooming."
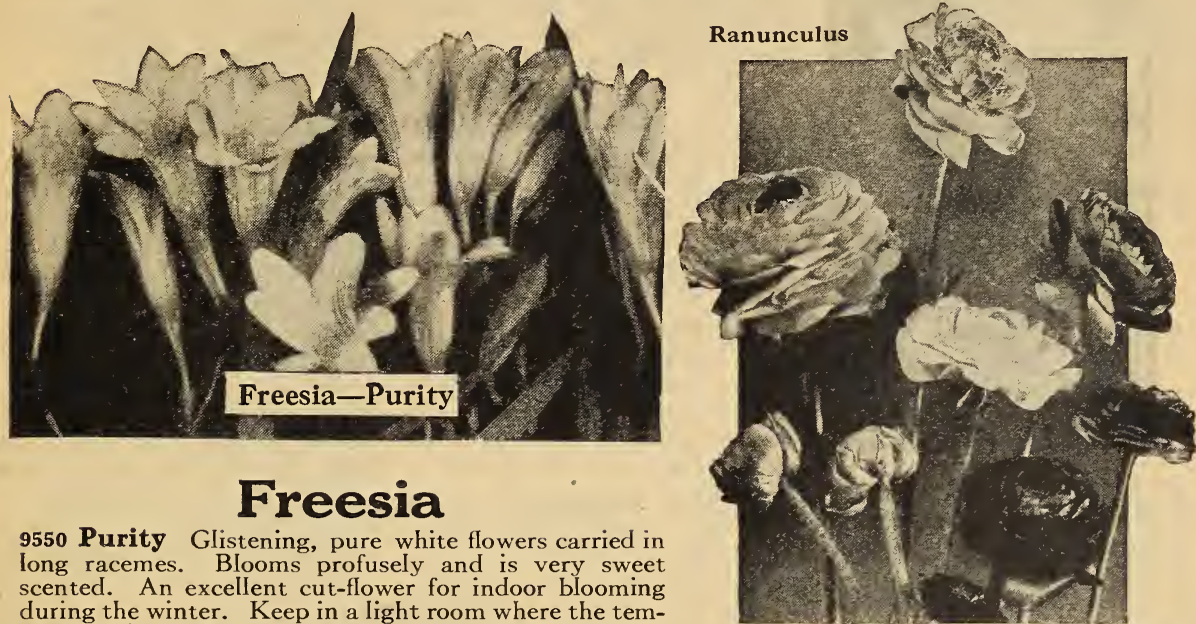

\section{Freesia}

9550 Purity Glistening, pure white flowers carried in long racemes. Blooms profusely and is very sweet scented. An excellent cut-flower for indoor blooming during the winter. Keep in a light room where the temperature is about 50 degrees $F$., where they will flower freely. Each stem carries five to eight large tubular florets. 6 for $35 \phi ; 12$ for $65 \phi ; 50$ for $\$ 2.35 ; 100$ for $\$ 4.50$.

9557 Rainbow Hybrids A beautiful strain with flowers ranging through yellow, lavender, pink, and purple-all very beautiful and delicate. The fine flowers are carried on long wiry stems. 6 for 40 c; 12 for 70 c; 50 for $\$ 2.60$; 100 for $\$ 5.00 ; 500$ for $\$ 24.00$.

\section{Ranunculus}

8980 French Mixed Showy doubleflowers in many bright colors except blue. Grows 6 to 12 inches tall and makes a fine plant for winter blooming indoors. Plant the bulbs 3 inches deep in boxes and keep around 45 to 50 degrees until in bloom. 3 for $25 \phi ; 6$ for $45 \phi ; 12$ for $85 \phi ; 50$ for $\$ 3.10 ; 100$ for $\$ 6.00$.

\section{Calla}

8919 Ethiopica (Lily of the Nile) The well-known white Calla Lily, with its attractive white flowers carried on a long stem above the rich green foliage. It can be grown easily in a moderately warm room at a temperature of about 55 degrees $\mathrm{F}$. Very showy. $35 \notin$ each; 3 for $95 \notin ; 6$ for $\$ 1.80 ; 12$ for $\$ 3.50$. 8918 Elliottiana (Yellow Calla) A most attractive variety with rich golden yellow flowers contrasting sharply with the variegated foliage of deep green splashed with white. For March and April blooming start the bulbs indoors the Iatter part of October. 35 $\dot{c}$ each; 3 for 95 ; 6 for $\$ 1.80 ; 12$ for $\$ 3.50$.

\section{Amaryllis}

8903 Johnsoni A beautiful large trumpet-shaped crimson flower marked with a broad white stripe. Easily grown in the house in any moderately cool room. Barely cover the neck of the bulb and keep rather dry until it begins to sprout; then water regularly but not in excess. 75 e each; 3 for $\$ 2.05$; 6 for $\$ 3.95 ; 12$ for $\$ 7.75$.

8907 Giant American Hybrids Contains a wonderful assortment of bright colors. The flowers are all very large and carried on a strong stout stem. This is so easily grown, with hardly any care, that every flower lover should have a few plants to brighten the home during winter and spring.

65 c each; 3 for $\$ 1.75 ; 6$ for $\$ 3.35 ; 12$ for $\$ 6.55$.

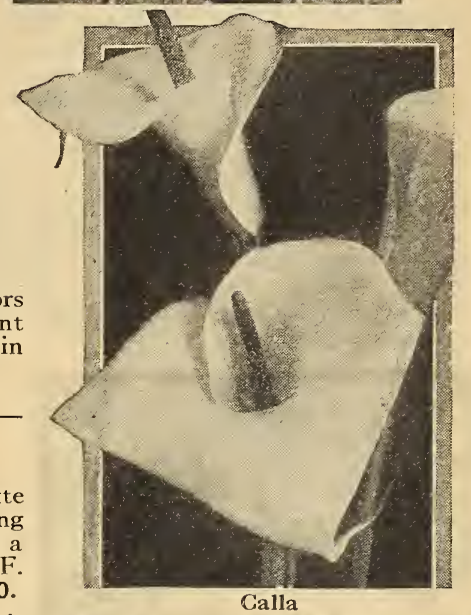




\section{Hardy Perennial Plants}

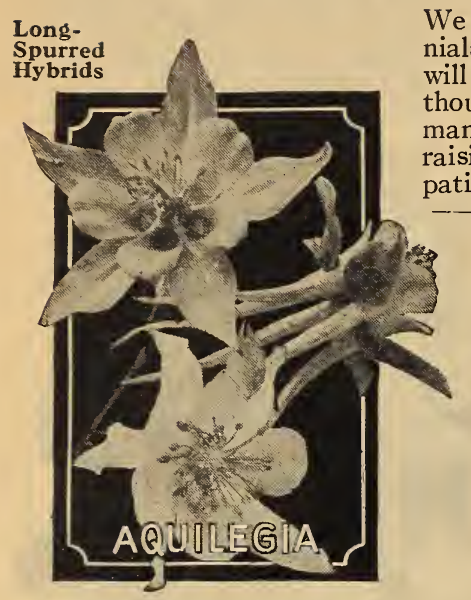

\section{Aquilegia-Columbine}

8900 Long-Spurred Hybrids

Our strain of this graceful free-blooming perennial is unexcelled. It includes a wonderful range of shades. Many are self colored in pink and light blue. Others combine blue and white, rose and white, yellow and blue, rose and yellow, and yellow and red, etc. Aquilegias are suitable for small as well as large plantings. They send forth during June a large number of strong, graceful spikes, carrying a mass of lovely slender-stemmed blooms. Perfectly hardy almost everywhere. $30 \notin$ each; 3 for $85 \notin ; 6$ for $\$ 1.60 ; 12$ for $\$ 3.05$; 25 for $\$ 6.00$; 50 for $\$ 11.90$.

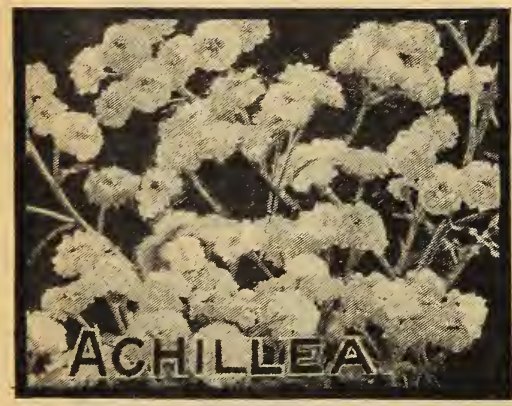

\section{Achillea}

8911 Ptarmica, Perry's White This lovely Achillea gives an excellent display planted as a border or mixed with other Perennials. It is also very valuable for cutting. The plants grow 2 feet tall and bear a profusion of fine double white blooms carried on long stems. Achillea does well in almost any kind of soil, even those which are comparatively poor and dry. We consider this variety the best in existence. $30 \not$ each; 3 for $85 \not ; 6$ for $\$ 1.65$; 12 for $\$ 3.20 ; 25$ for $\$ 6.25 ; 50$ for $\$ 12.40$.

\section{Delphinium-Hardy Larkspur}

No garden is complete without some of these beautiful longspiked flowers. Plant the roots about 4 feet apart and just lightly cover the top with an inch of fine soil. During severe freezing weather a mulch of straw or leaves, held in place by light boards or strings, will serve as winter protection.

8932 Bellamosum Strong stately spikes closely set with large double flowers of a rich dark blue color. Blooms freely during the month of June and gives a wonderful display in the garden. The spikes are also highly valued for cutting, as they last many days in water. $25 \notin$ each; 3 for $70 \not ; 6$ for $\$ 1.35 ; 12$ for $\$ 2.55 ; 25$ for $\$ 5.00 ; 50$ for $\$ 9.90$.

8931 Belladonna Perhaps this is the most popular of all the Hardy Delphiniums. The color of the flowers is a lovely light blue that defies description in its purity, softness, yet rich impression. The handsome spikes grow 4 to 6 feet tall and are covered with fine double blooms. We have a particularly fine strain of this. $25 \phi$ each; 3 for $70 \notin$; 6 for $\$ 1.35 ; 12$ for $\$ 2.55 ; 25$ for $\$ 5.00 ; 50$ for $\$ 9.90$.

8934 Gold Medal Hybrids A truly marvelous mixture of strong growing stately Delphiniums, including every shade from nearly white through light blue, deep blue, into rich and velvety shades of light and dark purple. 3 for $65 \phi$; 6 for $\$ 1.20 ; 12$ for $\$ 2.25 ; 25$ for $\$ 4.40$.

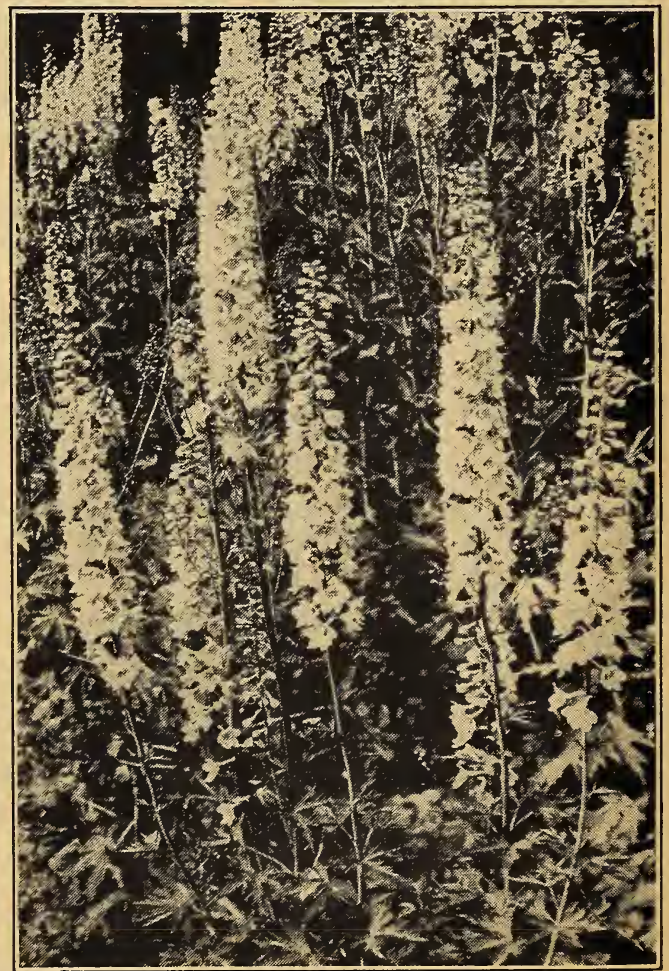




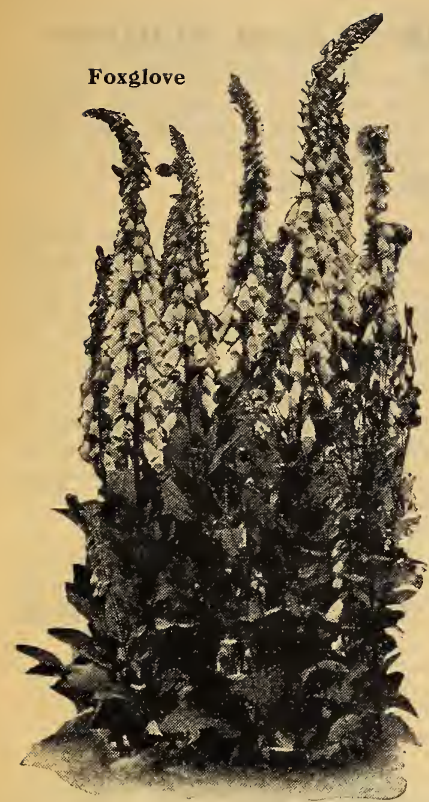

\section{Foxglove-Digitalis}

8683 Gloxinia-Flowered This is more or less a woodland plant which thrives best in combination with shrubs or other perennials which will provide a certain amount of shade to the roots of the Foxglove. Our strain includes a wide range of colors. The plants are strong growing and produce handsome spikes closely set with fine double bell-shaped blooms. 3 for $65 \phi ; 6$ for $\$ 1.20 ; 12$ for $\$ 2.25$; 25 for $\$ 4.40$.

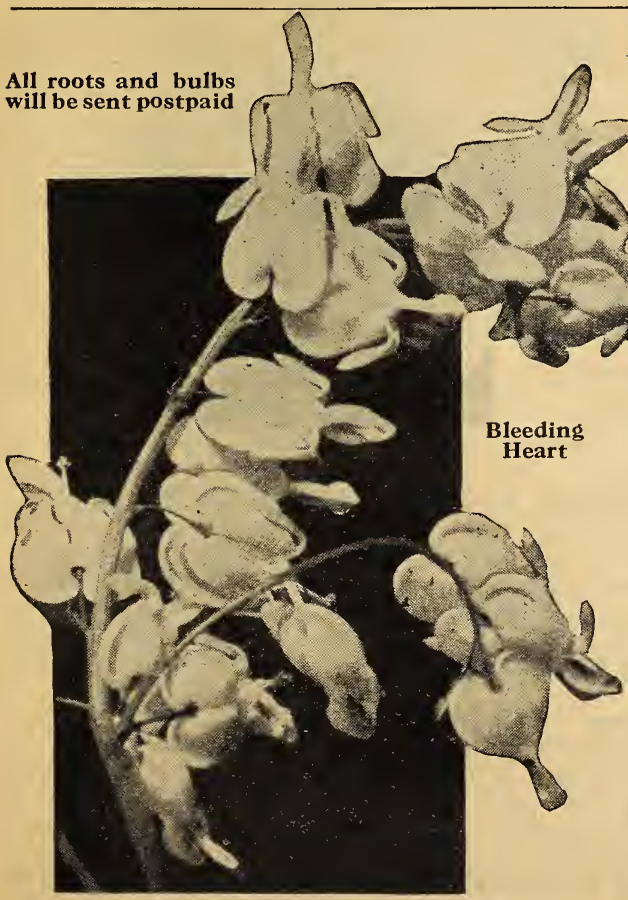
ilac. $30 \notin$ ea ch 3 for $85 \notin$; 6 for $\$ 1.60$; 12 for $\$ 3.05$.

\section{Funkia-Day Lily}

8933 Undulata Variegata This variety combines the showiness of its flowers with the showiness of long pointed leaves are bright green beautifully marked with white. Even when not in flower, ance. The flowers are borne on blooms are borne in clusters and are a beautiful shade of light

Funkias are easily grown in almost any kind of soil but they shaded spot where they will not particularly during the summer. This Funkia is perfectly hardy

$$
\text { ersist continuously. }
$$
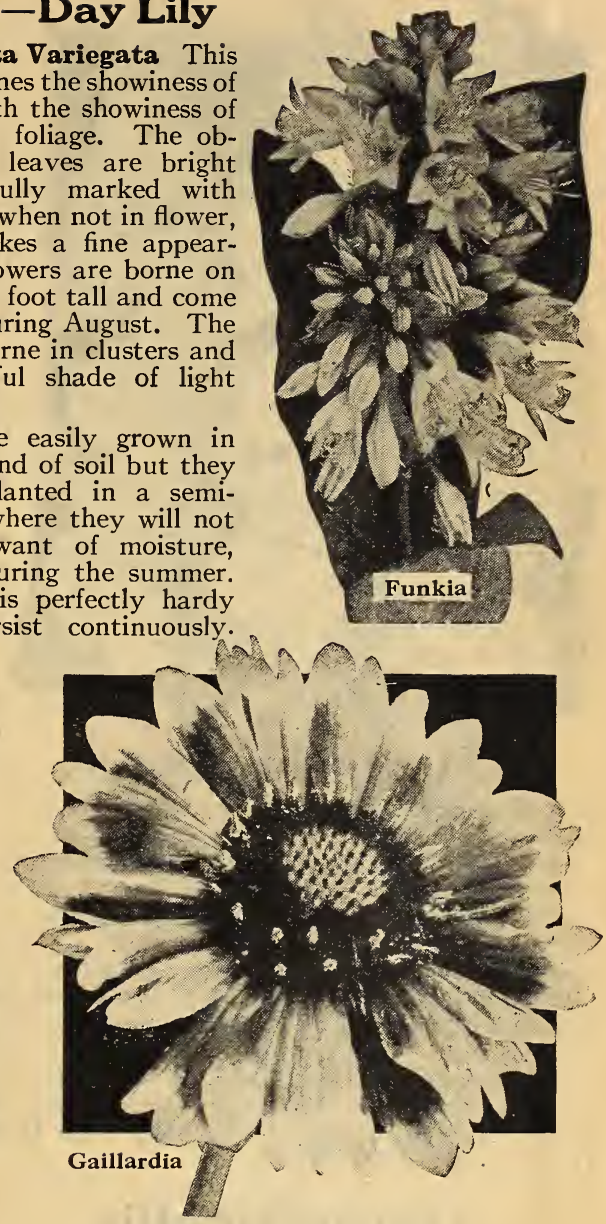

\section{Gaillardia}

8676 Mixed This is also known under the name of Blanket Flower, perhaps because the bright yellow and red colors of the flowers have a certain resemblance to an Indian blanket. The flowers are carried on fine long stems and, in addition to making a fine display in the garden, they are much in demand as cut-flowers. $30 \varnothing$ each; 3 for $65 \not ; 6$ for $\$ 1.25 ; 12$ for $\$ 2.40$.

\section{Bleeding Heart}

9610 Dicentra spectabilis The Bleeding Heart is one of the earliest blooming of all Perennials. The plants make a sturdy bushy growth 2 feet tall and they may be used either as specimen plants, mixed in the Perennial border, or for planting in the foreground of shrubbery.

Bleeding Heart requires plenty of moisture during the growing season and a moderately heavy soil. A semi-shaded or sunny position is to be given the preference. The heart-shaped rosepink flowers are borne freely above the Fern-like foliage. Blooms during April and May. The plants are ready for shipment in October. $55 \not$ each; 3 for $\$ 1.45 ; 6$ for $\$ 2.80 ; 12$ for $\$ 5.50$. 


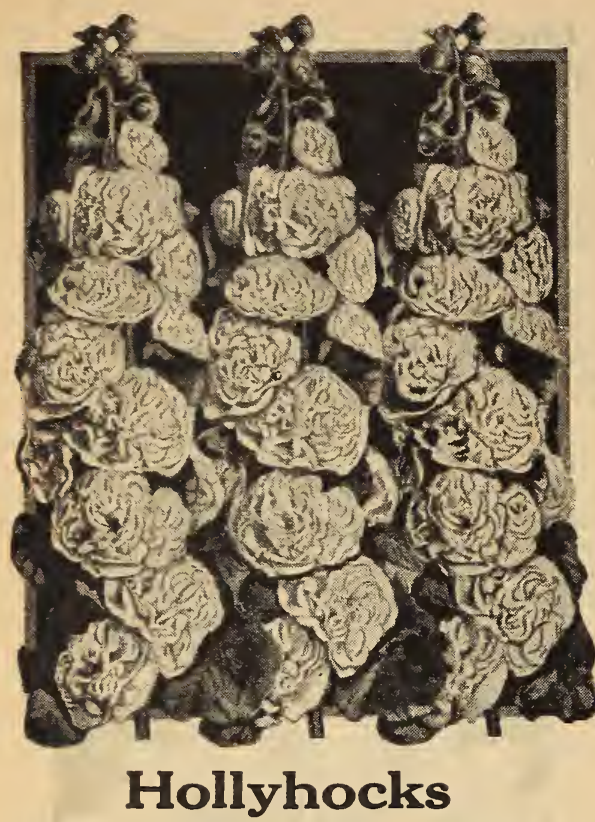

\section{Hibiscus-Giant Mallows}

9620 Giant Red A wonderful free-flowering Perennial which thrives best in fairly moist soil. Makes a strong growth 5 to 8 feet tall. Magnificent large flowers of a dark red-crimson shade. $30 \notin$ each; 3 for $75 \not ; 6$ for $\$ 1.40 ; 12$ for $\$ 2.65$.

9618 Giant Pink A lovely bright pink flower borne profusely on long, strong canes. The silky finish of the blooms and their enormous size always attract attention. The individual blooms measure 5 inches across. $30 \not$ each; 3 for $75 \not ; ; 6$ for $\$ 1.40 ; 12$ for $\$ 2.65$.

9622 Giant White A lovely companion to the two other varieties, with satiny white flowers forming a sharp contrast to the rich green foliage. A strong grower, blooming profusely for quite some time. $30 \not$ each; 3 for $75 \not ; 6$ for $\$ 1.40 ; 12$ for $\$ 2.65$.

9624 Giant Mixed This mixture includes shades of pink, rose, crimson, and also pure white. Excellent for mass planting. $25 \notin$ each; 3 for $70 \notin ; 6$ for $\$ 1.30$; 12 for $\$ 2.45$.

8678 Double Mixed Whether it is an oldfashioned garden you are planting or whether your design follows the modern trend, you should include Hollyhocks, as no other Perennial will give to your garden such stately effect. Most Perennials are quite bushy even though they may grow 2 to 3 feet tall, and Hollyhocks, with their strong upright spikes, are much needed to break the lines or serve as a background. Our mixture includes a wide range of beautiful colors. The flowers are extremely large, fully double, and they are closely set along handsome spikes. 3 for $65 \notin ; 6$ for $\$ 1.20$; 12 for $\$ 2.25 ; 25$ for $\$ 4.40$.

\section{Hemerocallis}
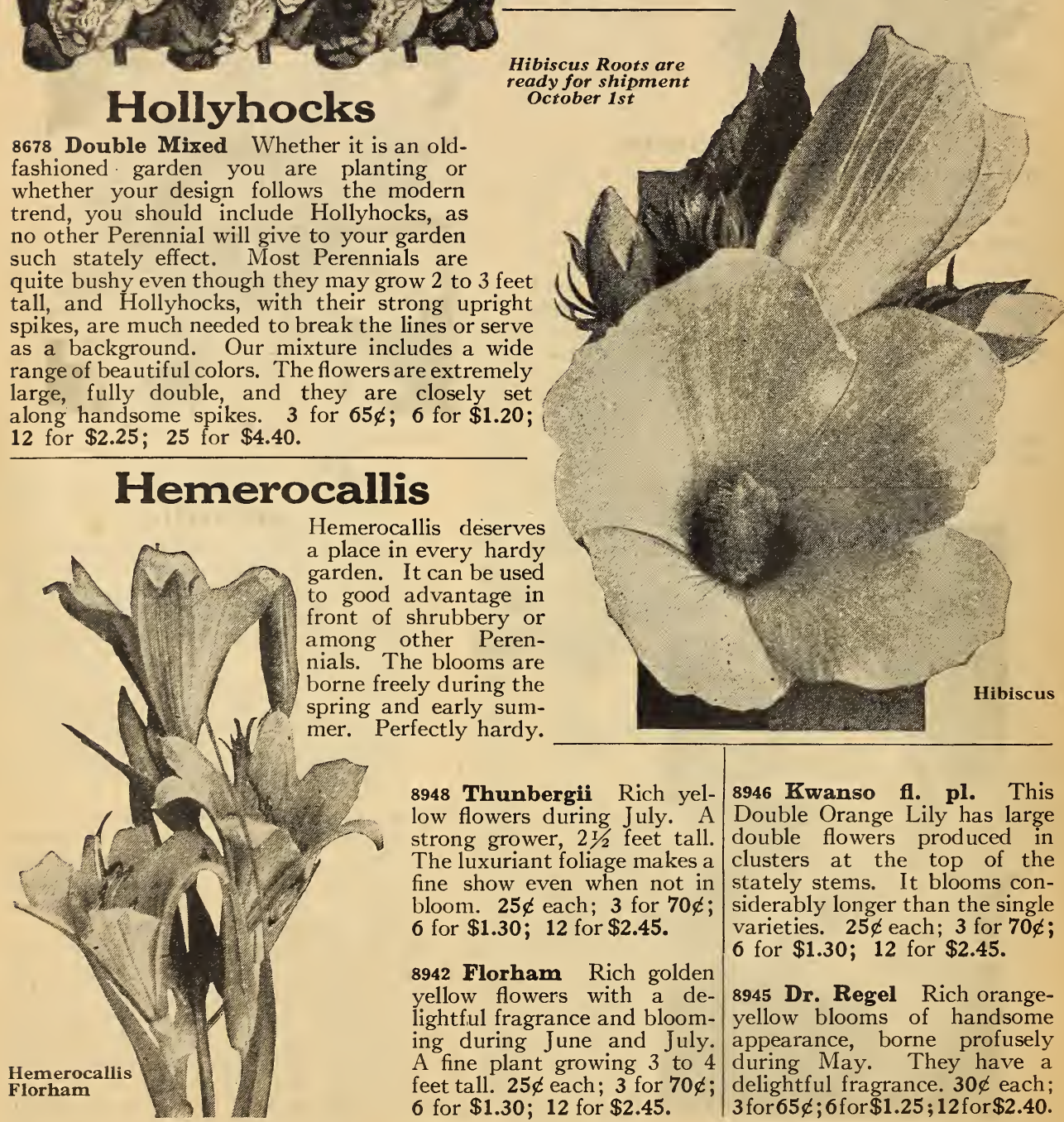

8948 Thunbergii Rich yellow flowers during July. A strong grower, $2 \frac{1}{2}$ feet tall. The luxuriant foliage makes a fine show even when not in bloom. $25 \notin$ each; 3 for $70 \notin$; 6 for $\$ 1.30 ; 12$ for $\$ 2.45$.

8942 Florham Rich golden yellow flowers with a delightful fragrance and blooming during June and July. A fine plant growing 3 to 4 feet tall. $25 \phi$ each; 3 for $70 \not$; 6 for $\$ 1.30 ; 12$ for $\$ 2.45$.
8946 Kwanso fl. pl. This Double Orange Lily has large double flowers produced in clusters at the top of the stately stems. It blooms considerably longer than the single varieties. $25 \notin$ each; 3 for $70 \notin$; 6 for $\$ 1.30 ; 12$ for $\$ 2.45$.

8945 Dr. Regel Rich orangeyellow blooms of handsome appearance, borne profusely during May. They have a delightful fragrance. $30 \varnothing$ each; 3 for $65 \notin ; 6$ for $\$ 1.25 ; 12$ for $\$ 2.40$. 


\section{Oriental Poppies}

Words could never describe the splendor of the Oriental Poppies. Such a richness and brilliancy of color and such regal splendor are not combined in many other Perennial plants. After the plants have become established they will produce a wealth of blooms year after year. They will last in water if cut when the buds open.

8679 Orientale (Scarlet) Brilliant orange-scarlet blooms of magnificent size standing out sharply from the dark green foliage. Remember that Oriental Poppies die down during the late summer to start new growth a few weeks later in the fall. $35 \not$ each; 3 for $80 \notin ; 6$ for $\$ 1.50 ; 12$ for $\$ 2.90$.

8680 Mrs. Perry A popular variety with beautiful large flowers of a soft salmon-rose shade. Very showy and always much admired. Blooms freely and makes a wonderful display during the spring. This also dies down during the summer to start into new growth a few weeks later. $35 \not$ each; 3 for $80 \varnothing$; 6 for $\$ 1.50 ; 12$ for $\$ 2.90$.
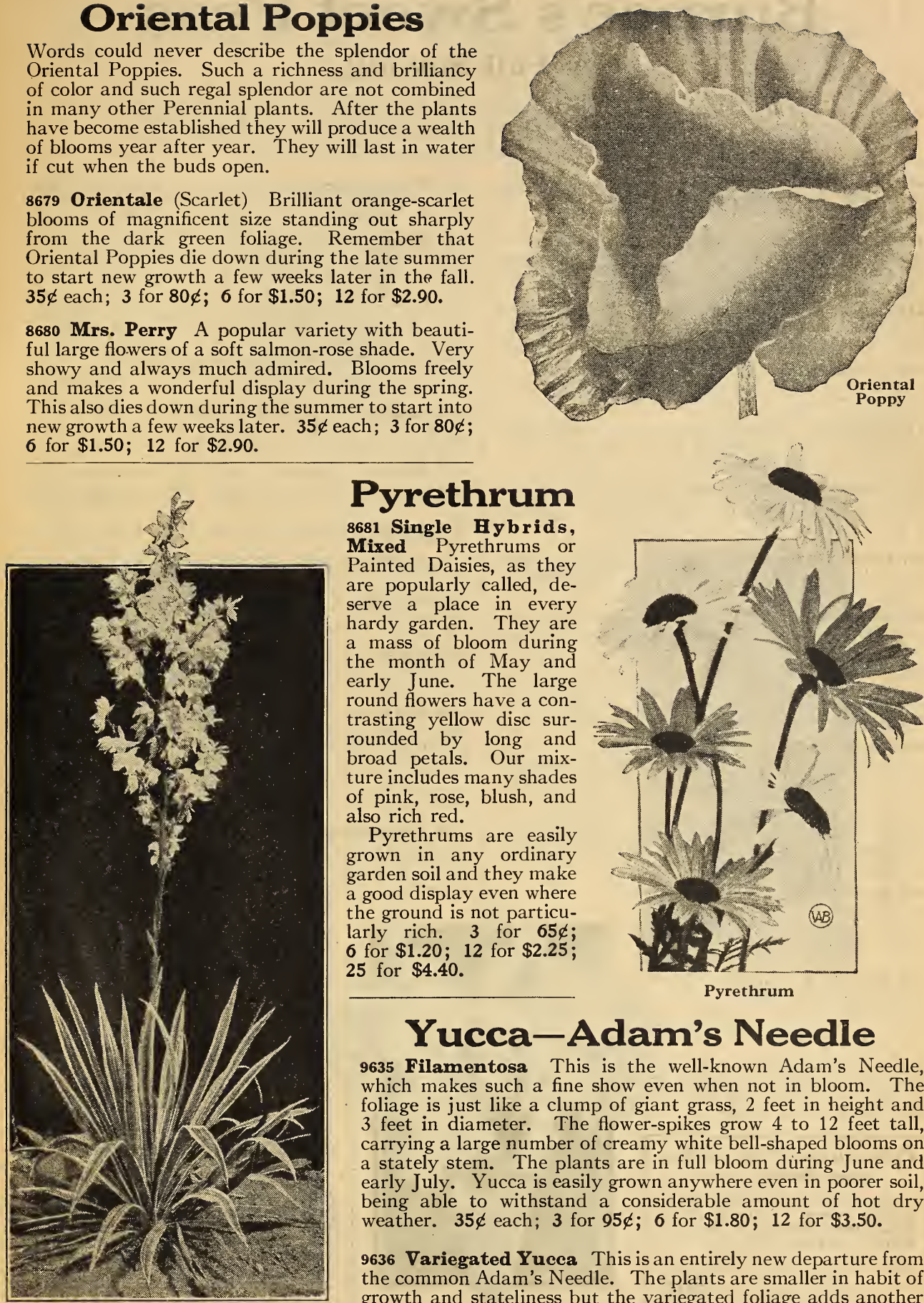

\section{Pyrethrum} 8681 Single Hybrids, Mixed Pyrethrums or Painted Daisies, as they are popularly called, deserve a place in every hardy garden. They are a mass of bloom during the month of May and early June. The large round flowers have a contrasting yellow disc surrounded by long and broad petals. Our mixture includes many shades of pink, rose, blush, and also rich red.

Pyrethrums are easily grown in any ordinary garden soil and they make a good display even where the ground is not particularly rich. 3 for $65 \phi$; 6 for $\$ 1.20 ; 12$ for $\$ 2.25$; 25 for $\$ 4.40$.

\section{Yucca-Adam's Needle}

9635 Filamentosa This is the well-known Adam's Needle, which makes such a fine show even when not in bloom. The foliage is just like a clump of giant grass, 2 feet in height and 3 feet in diameter. The flower-spikes grow 4 to 12 feet tall, carrying a large number of creamy white bell-shaped blooms on a stately stem. The plants are in full bloom during June and early July. Yucca is easily grown anywhere even in poorer soil, being able to withstand a considerable amount of hot dry weather. $35 \notin$ each; 3 for $95 \notin ; 6$ for $\$ 1.80 ; 12$ for $\$ 3.50$.

9636 Variegated Yucca This is an entirely new departure from the common Adam's Needle. The plants are smaller in habit of growth and stateliness but the variegated foliage adds another outstanding feature. The broad sword-like leaves are attractively striped and variegated with bands of white and creamy yellow. This is as easily grown as Filamentosa. The flowers are bell shaped, of a creamy white color, and they are carried in large clusters on strong stems measuring 4 to 12 feet tall. $90 \not$ each; 3 for $\$ 2.50$; 6 for $\$ 4.85$.

This illustration gives an idea of the excellent habit of the new Variegated Yucca.

Yucca plants are ready for shipment in October 


\section{Burpee's Sweet Peas \\ For Fall Sowing}

All the varieties of Sweet Peas listed below belong to the late or summer flowering type. This is the type for planting in the garden, but is not suited for growing indoors in the greenhouse. Every Sweet Pea lover should at least sow a short row of Sweet Peas during the fall, and our leaflet, "How to Grow Sweet Peas," gives full instructions. Write for a free copy of it. Fall-sown Sweet Peas begin to bloom early in the season and produce usually a much larger crop of flowers.

3412 Blue Bird A very fine blue variety of large size and brilliant coloring. Of exquisite texture. Pkt. 15k; $1 / 2 \mathrm{oz}$. $40 \xi ;$ oz. $75 k ; 4$ ozs. $\$ 2.40 ; 1 / 2$ lb. $\$ 4.40 ; 1$ b. $\$ 8.00$.

3475 Burpee's Giant White A gigantic flower of exquisite form and pure color. Carries four fine flowers on a long and strong stem. Black-seeded. Pkt. 10 $\dot{1} ; \mathrm{I} / 2 \mathrm{oz}$. $25 k ;$ oz. $35 \xi ; 4$ ozs. $90 k ; 1 / 2$ lb. $\$ 1.65 ; 1 b . \$ 3.00$.

3417 Colne Valley An attractive and glistening light blue variety with blooms borne in fours on long stems. Pkt. 10 $1 / 2$ oz. $25 \xi ;$ oz. $35 k ; 4$ ozs. $90 \notin ; 1 / 2$ lb. $\$ 1.65 ; 1 b . \$ 3.00$.

3461 Crimson King In our opinion this Sweet Pea is the finest of all true crimson shades. Pkt. 10 $;$; 12 oz. 25 oz. $40 \notin ; 4$ ozs. $\$ 1.20 ; 1 / 2$ lb. $\$ 2.25 ; 1$ lb. $\$ 4.00$.

3419 Daffodil A vigorous variety, with lovely sweetscented blooms of a rich creamy white. Pkt. 10k; $1 / 2 \mathrm{Oz}$. $25 \notin$; oz. $40 \notin ; 4$ ozs. $\$ 1.20$; 1/2 lb. $\$ 2.25 ; 1 \mathrm{~b}$. $\$ 4.00$.

3439 Daisybud Truly a lovely Sweet Pea, combining harmonious shades of apple-blossom pink with cream. Large, well waved, and most artistic. Pkt. 10 $\xi ; 1 / 2$ oz. 20 oz. $30 \notin ; 4$ ozs. $75 \xi ; 1 / 2$ lb. $\$ 1.40 ;$ lb. $\$ 2.50$.

3467 Edna May Improved A large flowering pure white variety of exquisite form and texture. Pkt. 10k; $1 / 2 \mathrm{oz} .25 \phi$; oz. $35 \notin ; 4$ ozs. $90 \notin ; 1 / 2$ lb. $\$ 1.65 ; 1 b . \$ 3.00$.

3457 Floradale Purple This has been for years the leading purple Sweet Pea in existence. Pkt. 10k; $1 / 2$ oz. 25 oz. $35 \xi ; 4$ ozs. $90 k ; 1 / 2$ lb. $\$ 1.65 ; 1$ b. $\$ 3.00$.

3465 Fordhook Orange This is unsurpassed in color. The blooms are bright orange and can withstand a lot of sun without scalding. Always much admired. Pkt. 15k; $1 / 2 \mathrm{oz}$ 25 ; ; oz. 40 ; 4 ozs. $\$ 1.35 ; 1 / 2$ lb. $\$ 2.50 ; 1 b . \$ 4.50$.

3469 George Shawyer The standard is a fine shade of bright orange-salmon and the wings are tinted rose. The general effect is orange-pink. Blooms most profusely. Pkt. $10 k ; 1 / 2$ oz. 25 ; oz. 35 ; 4 ozs. 90k; $1 / 2$ lb. $\$ 1.65 ; 1 \mathrm{~b} . \$ 3.00$.

3558 Grenadier Bright Geranium-red with a vivacity and richness that is simply startling. Large, well waved and of rich texture. Pkt. 15 ; I $/ 2$ oz. $40 \notin ;$ oz. $70 \notin ; 4$ ozs. $\$ 2.25$; $1 / 2$ lb. $\$ 4.15 ; 1 \mathrm{~b}$. $\$ 7.50$.

3481 Honor Bright A deep rose-pink sweet-scented variety with a cream ground. Exceptionally beautiful. Pkt. $1 / 2$ lb. $\$ 1.95$; lb. $\$ 3.50$

3522 Mrs. C. P. Tomlin Bright scarlet with just a touch of fiery red. A striking variety. Pkt. 10k; I/2 oz. 20k; oz. 30k;

$1 / 2$ lb. $\$ 1.40 ; 1 b . \$ 2.50$.

3538 New Wedgwood clear blue flower of great a large Pkt. 10\&; 1/2 oz. 20\&; oz. 30\&; 4 ozs. $75 \phi ; 1 / 2$ lb. $\$ 1.40 ; 1 b . \$ 2.50$.

\section{Collections of Six of the} Best Sweet Peas

These collections contain: Colne Valley, Sunset, Crimson King, Sunshine, Burpee's Giant White, and Blue Bird.

7330 One packet each. Will plant 20 feet of row. Value 70k, for

$50 \varnothing$

7331 One-half ounce each plant 75 feet of row. 1 Value $\$ 1.80$, for

$\$ 1.25$

7332 One ounce each. Will plant 150 feet of row $\$ 2.50$
Honor Honor
Bright
3540 Orchid Improved Clear Cattleya-lavender flowers borne profusely in fours on long stems. Pkt. 10 $\&$ I $/ 2 \mathrm{oz}$ $20 k$; oz. $30 k ; 4$ ozs. $75 k ; 1 / 2$ lb. $\$ 1.40 ; 1 b . \$ 2.50$.

3548 Picture A charming combination of cream and pink shades with a deeper flush on the wings. Pkt. 10k; 1/2 oz. $20 \notin ;$ oz. 30k; 4 ozs. $75 \xi ; 1 / 2$ lb. $\$ 1.40 ;$ lb. $\$ 2.50$.

3553 Pink Perfection An exceptionally fine pink variety with a touch of salmon. Large and substantial. Pkt. 15k; $1 / 2$ oz. $40 \notin ;$ oz. $70 \notin ; 4$ ozs. $\$ 2.25 ; 1 / 2$ lb. $\$ 4.15 ;$ lb. $\$ 7.50$.

3570 Royal Scot A brilliant and lustrous orange-scarlet flower with a deep cerise sheen. Pkt. $10 \phi ; 1 / 2$ oz. $20 k$; oz. $30 \notin ; 4$ ozs. $75 \notin ; 1 / 2$ lb. $\$ 1.40 ; 1$ b. $\$ 2.50$.

3584 Sapphire A clear and pure blue. Magnificent blooms carried in fours on long stems. Pkt. 15 $;$; $1 / 2 \mathrm{oz} .25 \xi$ oz. 40 ; 4 ozs. $\$ 1.35 ; 1 / 2$ lb. $\$ 2.50 ; 1$ b. $\$ 4.50$.

3577 Sunset A beautiful shade of rich soft rose with a gleam of yellow at the base. Blooms most profusely. Pkt. $10 k ; 1 / 2$ oz. $25 \xi ;$ oz. $35 \xi ; 4$ ozs. $90 \xi ; 1 / 2$ lb. $\$ 1.65 ; 1 b . \$ 3.00$.

3448 Sunshine Bright Hermosa pink blooms with a blotch of Primrose at the base. Reverse shaded amber. A large and well-waved flower. Pkt. 15 $\dot{1} ; 1 / 2$ oz. $40 k$; oz. $70 \& ; 4$ ozs. $\$ 2.25 ; 1 / 2$ lb. $\$ 4.15 ;$ lb. $\$ 7.50$.

3595 Supreme This ranks as one of the best clear pinks. It is a soft and delicate color. Pkt. 20k; $1 / 2 \mathrm{oz} .50 k ; 0 z .90 \notin ;$ 4 ozs. $\$ 3.00 ; 1 / 2$ lb. $\$ 5.50 ;$ lb. $\$ 10.00$.

3591 Warrior A rich reddish maroon color. Very unusual and quaint, and always greatly admired. Pkt. 10\&; $1 / 2 \mathrm{oz}$ $20 \notin ;$ oz. $30 \notin ; 4$ ozs. $75 \xi ; 1 / 2$ lb. $\$ 1.40 ;$ lb. $\$ 2.50$.

3599 The Burpee Blend This popular mixture of Giant Spencer Sweet Peas is planted each year by many thousands of our customers who like to have a showy row of the finest mixed Sweet Peas. The Burpee Blend contains the very best varieties and includes the proper quantity of the various colors to make a fine display. Pkt. 10k; $1 / 2 \mathrm{oz}$. 20k; oz. $30 \notin ; 4$ ozs. 75 ; $1 / 2$ lb. $\$ 1.40 ; 1$ b. $\$ 2.50$

3600 Mixture of Light Shades Some of our customers do not care for the deeper colored Sweet Peas and we have prepared this special mixture which contains only the lighter shades, such as white, cream, pink, salmon, lavender, and other delicate shades. Pkt. 10 $k ; 1 / 2$ oz. 25k; oz. 35 4 ozs. $90 \notin ; 1 / 2$ lb. $\$ 1.65 ; 1 \mathrm{~b}$. $\$ 3.00$.

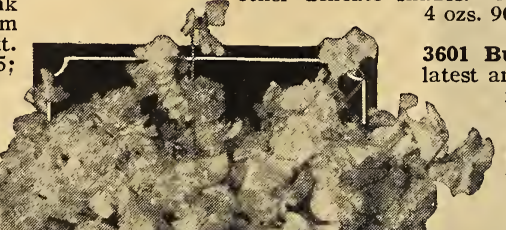

601 Burpee Novelty Mixture The nd very finest varieties of recent introductions have been used to make this special mixture. It also contains a number of new seedlings from our California workshop of Sweet Peas-Floradale Farms. All the leading colors are represented in the mixture in their proper proportions. Pkt. 10\&; $1 / 2$ oz. 25 ; oz. $40 k$ 4 ozs. $\$ 1.20 ; 1 / 2$ lb. $\$ 2.25 ; 1 \mathrm{~b}$. $\$ 4.00$.

Collections of Twelve of the Best Sweet Peas

These collections contain: Colne Valley, Sunset, Crimson King, Sunshine, Burpee's Giant White, Blue Bird, Daffodil, Pink Perfection, Supreme, Fordhook Orange, Grenadier, and Floradale Purple.

7340 One packet each. Will plant 40 feet of row. Value $\$ 1.00$
$\$ 1.55$, for

7341 One-half ounce each. Will plant 150 feet of row. Value $\$ 2.50$

7342 One ounce each. Will plant 300 feet of row. Value $\$ 4.50$ 


\section{Perennial Flower Seeds}

Perennials are the chief standby of the old-fashioned gardens. They require little attention and respond generously to increased care and thorough cultivation. After once being established they will not only last many years but also increase in beauty with every season. The seed of perennials may be sown indoors almost any time of the year. Summer and fall sown seed should best be made in specially prepared beds, preferably boxed in with 8 or 10 inch boards and covered with a screen of lath or wide-meshed burlap. During the winter a covering of leaves or strawy manure after the frost has touched the foliage is all the protection needed.

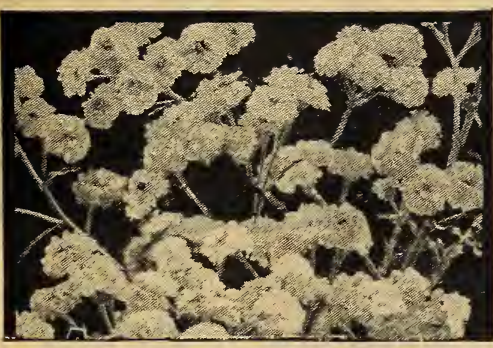

Achillea 3702 Ptarmica, fl. pl. Pearl Achillea (Milfoil; Yarrow) Small double white flowers borne in great profusion; 2 feet tall. Grows well in any kind of soil even if partly shaded. Blooms freely during July and August and is very fine for borders and cutting. Pkt. $15 \phi ; 1 / 16$ oz. $65 \phi ; 1 / 8$ oz. $\$ 1.10 ; 1 / 4$ oz. $\$ 1.90$.

\section{Bellis-}

Double English Daisy

These are indispensable for cool shady places. They bloom very early in the spring.

3724 Longfellow Extra-large double flowers of dark rose. They are wonderful for beds or borders. Pkt. $15 \phi ; 1 / 8$ oz. $50 \phi ; 1 / 4$ oz. $85 \phi$.

3725 Snowball A free-blooming strain with beautiful double white flowers. Pkt. 15 ; $1 / 8$ oz. $50 \notin$ : $1 / 4$ oz. $85 \phi ; 1 / 2$ oz. $\$ 1.45$.

3726 Double Mixed White and various shades of rose and red in mixture. Pkt. $10 \notin ; 1 / 8$ oz. $75 \not ;$; $1 / 2$ oz. $\$ 1.25$.

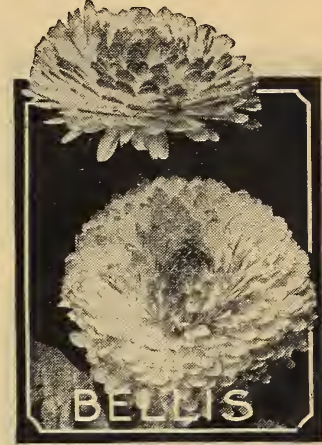

Boston IVy 3708 (Ampelopsis Veitchii) The favorite hardy climber with large five-lobed leaves ming to a bright red color late in the fall. It easily clings to walls of wood, brick, or stone. Pkt. $10 \notin ; 1 / 4$ oz. 25 $\not ; 1 / 2$ oz. $40 \notin ;$ oz. $70 \notin$.

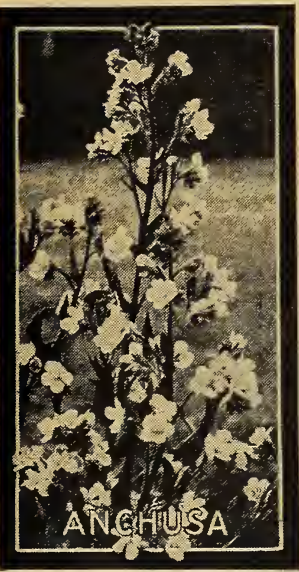

\section{Anchusa}

3710 Italica Dropmore Variety (Alkanet or Bug loss) One of our finest blue-flowered plants, growing 4 feet tall. Magnificent spikes from June on. An excellent plant for the background. Pkt. $10 \not$; $1 / 8$ oz. $25 \phi ; 1 / 4$ oz. $35 \phi$.

\section{Agrostemma}

3704 Mixed White, rose,

and rich crimson flowers from May to July; 2 feet tall. Pkt. $10 \notin ; 1 / 4$ oz. 25 $\varnothing$.

\section{Arabis}

3720 Alpina An excellent dwarf perennial, blooming very early in the spring. The thick green tufts of leaves are nearly hidden by a profusion of small white flowers. Pkt. 10 $\varnothing ; 1 / 4 \mathrm{oz}$. $25 \notin ; 1 / 2$ oz. $40 \notin ;$ oz. $70 \notin$.

Aquilegia $\mathbf{3 7 1 4}$ Cærulea (The Rocky Mountain flowers borne profusely during May and June. Pkt. 10 $\varnothing$; $1 / 8$ oz. $45 \notin ; 1 / 4$ oz. $75 \phi$.

3716 Long-Spurred Hybrids Fine long-spurred flowers during June. All colors. Pkt. $20 \notin ; 1 / 8$ oz. $65 \phi$.

\section{Campanula (Bellflowers) The Cam-} make a wonderful show during May and early June. 3733 Single Mixed White, pink, rose, blue, and purple shades. Pkt. $10 \notin ; 1 / 8$ 0z. 30 $\notin ; 1 / 4$ oz. $50 \phi$.

3734 Double Mixed The flowers are fully double and come in a wide range of bright colors; of strong growt and blooms freely. Pkt. $10 \phi ; 1 / 80 z .30 \phi ; 1 / 40 z .50 \phi$.

3743 Carpatica, Blue (Carpathian Harebell) Rich blue bell-shaped flowers on thin stems. Excellent for rockeries; 12 inches tall. Pkt. $15 \phi ; 1 / 80 z .35 \phi ; 1 / 4$ oz. $55 \phi$. 3744 Carpatica, White A pure white-flowered form of the above. Pkt. $15 \phi ; 1 / 8$ oz. $35 \phi ; 1 / 4$ oz. $55 \phi$. 3746 Persicifolia, Mixed (Peach Bells) Beautiful bellshaped flowers in blue and white. Pkt. 20ф; 1/8 0z. $65 \phi$. 3747 Pyramidalis Blue (Chimney Bellflower) Rich blue bell-shaped flowers borne on long wiry stems. Pkt. 15 $1 / 8$ oz. $35 \phi ; 1 / 4$ oz. $55 \phi$.

3745 Pyramidalis, White Pure white flowers carried on thin, wiry stems. Graceful and very profuse blooming. Pkt. 15 $\not ; 1 / 8$ oz. 35 $\not ; 1 / 4$ 0z. $55 \phi$.

\section{Carnation}

Perennial Carnations are easy to grow and make a showy display. They will bloom the first year if the seed is sown early in the spring. The long-stemmed flowers are excellent for cutting, lasting a long time in water. The plants make compact bushes 2 to 3 feet tall and bear a mass of large double flowers during July and August. 3751 Chabaud, White Large well-rounded flowers of pure white color. Pkt. 20 $\varnothing ; 1 / 8$ oz. 50 $1 / 4$ oz. $85 \not ; 1 / 2$ oz. $\$ 1.45$.

3752 Chabaud, Rose A lovely soft rose color. Always fully double. Pkt. 20 $\not$; $1 / 8$ oz. $50 \notin ; 1 / 4$ oz. $85 \phi$.

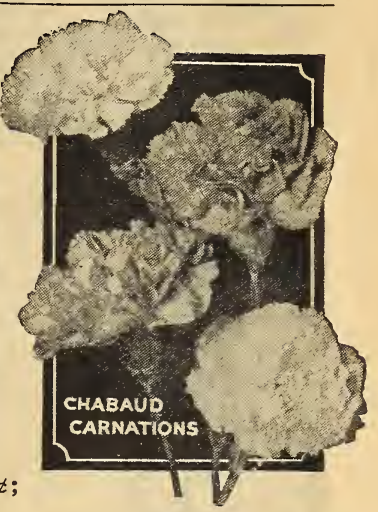

3753 Chabaud, Scarlet The flaming scarlet flowers are most impressive. The long-stemmed blooms are fully double and of large size. Pkt. $20 \notin ; 1 / 8$ oz. 50 $\varnothing ; 1 / 4$ 0z. $85 \phi$. 3754 Chabaud, Crimson-Maroon A deep shade of crimson with a garnet-maroon cast. The strong plants bear a great profusion of blooms. Pkt. $20 \notin ; 1 / 8$ 0z. $50 \phi ; 1 / 4$ 0z. $85 \phi$. 3756 Chabaud, Mixed This mixture includes the above and other fine colors. Pkt. $15 \phi ; 1 / 8$ 0z. $45 \phi ; 1 / 4$ oz. $75 \phi$.

3755 Double Mixed A fine strain of perennial Carnations with large flowers of many bright colors-white, pink, rose, scarlet. crimson, and maroon. Pkt. 15 $\phi ; 1 / 80 z .40 \phi ; 1 / 40 z 65 \phi$. 3757 Early Dwarf Vienna, Mixed The plants are dwarf and compact, making a fine display in the border or garden. All colors mixed. Pkt. $15 \phi ; 1 / 8$ oz. $35 \phi ; 1 / 4$ oz. $55 \phi$.

3915 Perpetual or Tree Mixed Immense flowers in all colors. Grown extensively for winter blooming in the greenhouse, also suited for outdoor culture in beds or borders. Includes a range of bright colors. The fine double flowers are carried on long stems. Pkt. $15 \phi ; 1 / 8$ oz. $50 \phi ; 1 / 4$ oz. $85 \phi$.

Centaurea 3763Montana(Hardy Cornflower) Chrows 2 feet tall and has large, the end of April until late June and is perfectly hardy. A sturdy growing and free-blooming variety which makes a fine display in the mixed border and will produce longstemmed cut-flowers during the late spring and summer. Pkt. $10 \phi ; 1 / 4$ oz. $30 \phi ; 1 / 2$ oz. 50ф; oz. $85 \phi$.

Cheiranthus 3765 Allionii Lovely orangeyellow flowers borne in great profusion during May. A neat little border plant, 12 inche tall. Sweet-scented. Pkt. $10 \phi ; 1 / 4$ oz. $45 \phi ; 1 / 2$ oz. $75 \phi$. 


\section{Chinese Lantern Plant}

3856 (Physalis Franchetti) The Chinese Lantern Plant is grown for its showy scarlet-red seed-pods which are easily dried for winter bouquets. The plants are perfectly hardy, blooming during June and July. The flowers are white. Easily grown in any kind of soil, whether sunny or semishaded. Pkt. $15 \phi ; 1 / 8$ oz. $35 \phi ; 1 / 4$ oz. $55 \phi ; 1 / 2$ oz. $95 \phi$.

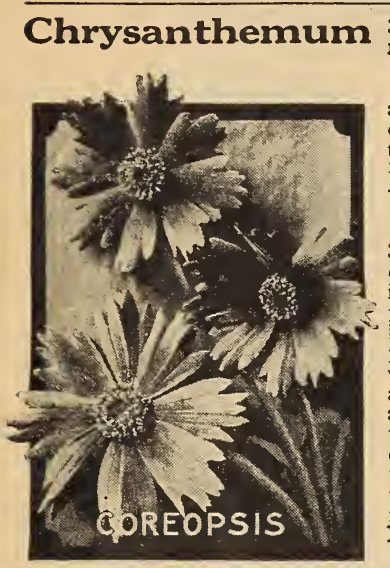

3750 Fordhook Early. flowering Single and semi-d ouble flowers measuring 3 inches across. A mixture of all colors, blooming during the late fall. Pkt. 25\&; $1 / 320 z .60 \not ; 11 / 16$ oz.\$1.05.

\section{Coreopsis}

3768 Grandiflora The color of the fine blooms is a most intense golden yellow. The petals are broad and open. The plants bloom freely and will make a fine display all during the late spring and summer. Coreopsis thrives in a rich, moderately moist soil, even in a semi-shaded location. It is exceptionally fine for cutting.

Pkt. 10 $\notin ; 1 / 4$ oz. $30 \notin$; $1 / 2$ oz. $50 \notin ;$; oz. $85 \notin$.

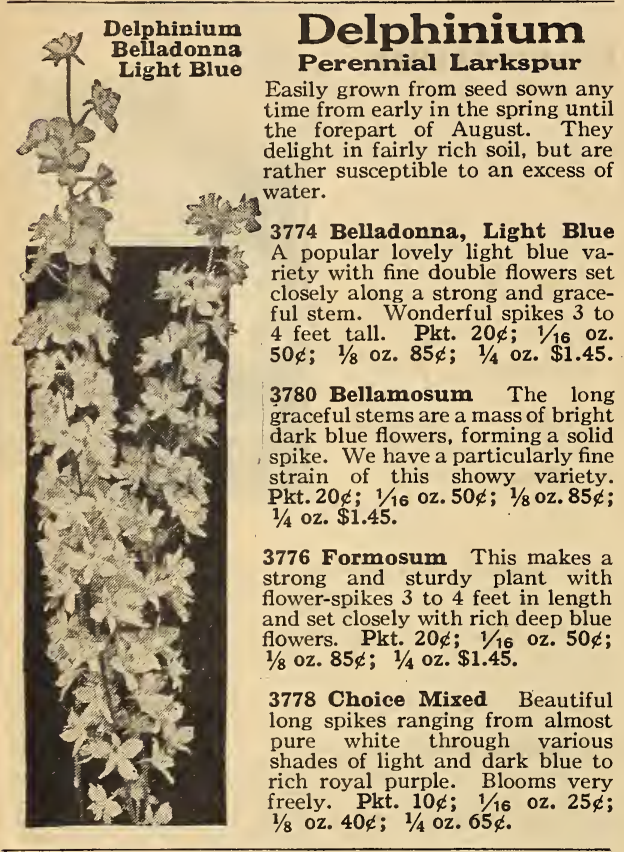

Dianthus These are very popular because they many weeks. They are valued for rock-gardens.

3783 Plumarius (Perennialor Pheasant-EyePink) Thick tufts of fine leaves. Many small, star-like, rich rose flowers. Delicately scented. Pkt. 10 $\varnothing ; 1 / 8$ oz. $30 \notin ; 1 / 4$ oz. $50 \phi$.

3785 Scoticus, fl. pl. (Paisley or Florists' Pink) A very pretty double variety of Perennial Pinks. Blooms during June; one foot tall. Pkt. 15 $\not ; 1 / 8$ oz. 40 $\not ; 1 / 4$ oz. $65 \phi$.

3781 Allwoodii An excellent double variety, blooming freely all summer long. Agreeably clove-scented flowers in all colors. A valuable variety, comparatively new. Pkt.35 $\phi$.

Erigeron 3797 Speciosus Superbus (Fleabane) Erigeron Single Daisy-like mauve-colored flowers produced in abundance throughout the summer. Grows 2 feet tall and is suited for mixed beds, borders, or rockgardens. Pkt. $15 \notin ; 1 / 16$ oz. $40 \notin ; 1 / 8$ 0z. $65 \notin ; 1 / 4$ oz. $\$ 1.10$.

\section{Floradale Daisy}

Those who love Daisies because of their simple graceful habit will be delighted with our Floradale Daisy. The fine pure white flowers grow to large size and are composed of gracefully curved, loose petals giving the whole flower a serni-double appearance. The flowers are of well-rounded form and grow about 2 feet tall. During the duces a wealth of fine longstemmed blooms excellent for cutting.

Pkt. 25 $\not$;

$1 / 16$ oz. $85 \propto$ $1 / 8$ oz. $\$ 1.45$.

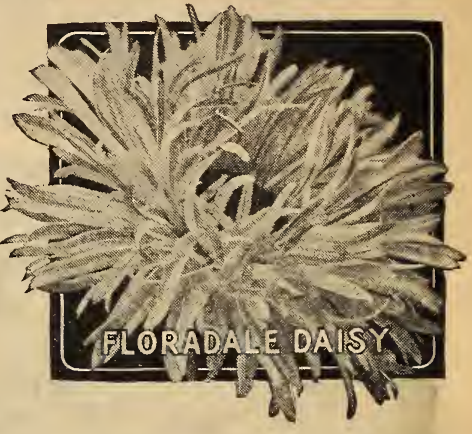

\section{Foxglove-Digitalis}

Beautiful tall spikes with gracefully drooping bell-shaped blooms in white and shades of pink, rose, yellow, and purple. Grows 4 feet tall and attains perfection in a semi-shaded position. Pkt. $10 \phi ; 1 / 16$ oz. $25 \phi ; 1 / 8$ oz. $40 \phi ; 1 / 4$ oz. $65 \phi$.

Gaillardia 3805 Grandiflora, Perennial Hybrids Very showy crimson flowers, tipped brilliant yellow. Grows 2 feet tall and makes a wonderful display during late June and July. Pkt. 10\&; $1 / 8$ oz. $25 \phi ; 1 / 4$ oz. $35 \phi ; 1 / 2$ oz. $55 \phi ;$ oz. $95 \phi$.

Geum 3806 Coccineum Mrs. Bradshaw AtGeum tractive double flowers of a most intense orange-scarlet color. Grows 2 feet tall and does well in a sunny location. Pkt. $15 \phi ; 1 / 16$ oz. $45 \phi ; 1 / 8$ oz. $75 \phi$.

3804 Lady Stratheden The grand double flowers are a magnificent golden yellow; 2 feet tall. It is a handsome Geum for mixed beds or borders. Very free blooming. Pkt. 20 $\not ; 1 / 16$ oz. $65 \not ; 1 / 8$ oz. $\$ 1.10 ; 1 / 4$ oz. $\$ 1.90$.

\section{Hardy Gloxinia 3831 (Incarvillea Del-}

produced in clusters on long stems and are shaped like a Gloxinia - a lovely shade of bright rose. They grow best in a soil containing plenty of leaf-mold.

The plants are hardy in the South, but in the North the roots should be lifted before severe frost sets in and stored like Dahlias in a cool but frostproof cellar. Pkt. 15 $\varnothing$; $1 / 16$ oz. $50 \not ; 1 / 8$ oz. $85 \not ; 1 / 4$ oz. $\$ 1.45 ; 1 / 2$ oz. $\$ 2.50$.

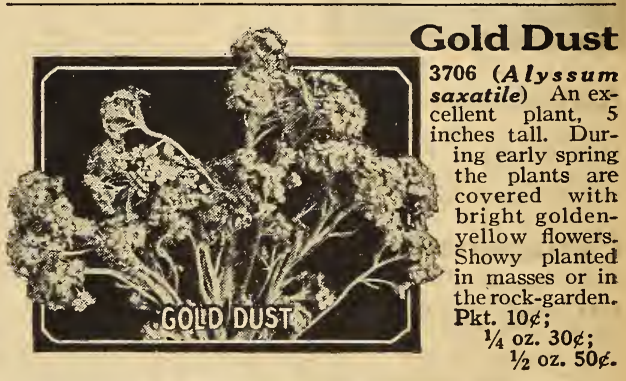

Helenium 3809 Autumnale Superbum ous-flowering plant with spreading heads of Daisy-like golden-yellow flowers. Grows 8 feet tall and blooms during summer and fall. Pkt. $15 \phi ; 1 / 16$ oz. $40 \phi ; 1 / 80 z .65 \phi$.

\section{Heuchera 3811 Sanguinea Hybrids The foli-} which rise numerous graceful flower-spikes. The colors abange from white through pink and rose to crimson. The spikes grow 12 inches tall. A very fine plant for the rock-garden, growing most freely in loose, rich soil. The plants bloom profusely from May until July. Pkt. 25 $\dot{1} ; 1 / 16$ oz. $65 \phi$; $1 / 8$ oz. $\$ 1.10 ; 1 / 4$ oz. $\$ 1.90 ; 1 / 2$ oz. $\$ 3.25$. 


\section{Hollyhocks}

Every old-fashioned garden must have Hollyhocks. They have been favorites for many generations and our present-day strains excel the old-fashioned type in size, freedom of flowering, strong constitution, and doubleness of the blooms. The plants grow 6 to 8 feet in height and produce their magnificent flower-spikes during June and July.

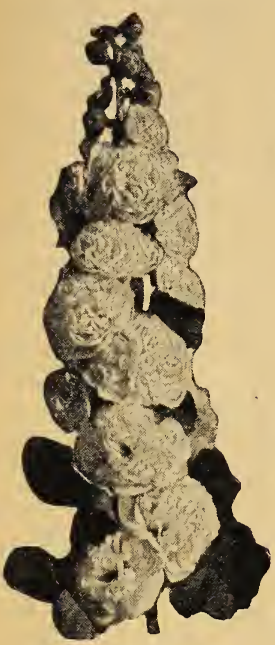

Double Hollyhocks

Our strain of Double Hollyhocks is without equal. It produces tall spikes closely set with rounded double flowers. The colors have been carefully selected as to purity and richness. The plants are sturdy, strong growing, and free flowering.

3814 Light Pink

3815 Maroon

3816 Rose

3817 Scarlet

3818 Yellow

3819 White

3820 Salmon-Pink

3823 Crimson

Any of the above:

Pkt. 15 $\not 11 / 8$ oz. $35 \notin ; 1 / 4$ oz. $55 \not$.

3822 Double Mixed All the separate colors listed above have been properly blended in this excellent mixture to make sure that it will give a showy display. Pkt. $10 \notin ; 1 / 8$ oz. $30 \notin ; 1 / 4$ oz. $50 \notin ;$ $1 / 2$ oz. $85 \varnothing$.

3828 Single Mixed There has always been quite a demand for Single Hollyhocks, particularly in mixture, because these bloom more continuously than the double flowered varieties. Pkt. $10 \notin$;

Double Hollyhocks

3826 Allegheny A most unusual but remarkably attractive type of Hollyhocks in which the edges of the individual flower petals are finely fringed and curled. This adds greatly to the attractiveness of the blooms and takes away somewhat of the stiff effect. This strain contains many colors in a bright assortment. The blooms are either single or semi-double. They are of large size; borne along a graceful and stately stem. Pkt. 10 $\not ; 1 / 8$ oz. 25 $\not ; 1 / 4$ oz. 35 $\not ; 1 / 2$ oz. $55 \phi$.

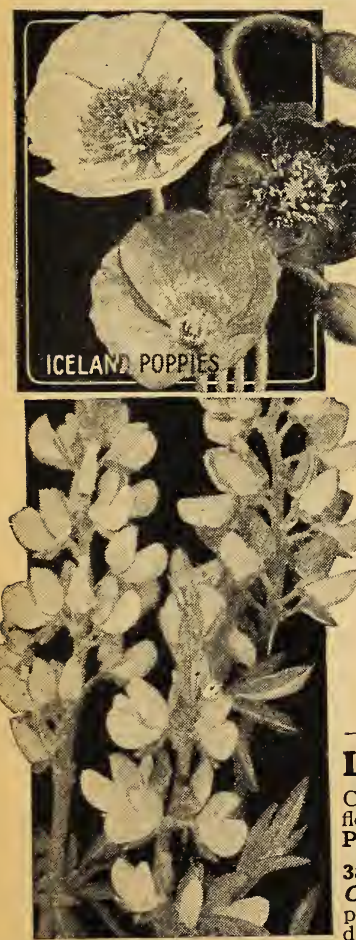

\section{Iceland Poppy}

3849 Mixed (Papaver nudicaule) The flowers are produced on fine stiff stems 18 inches long, and come in white, yellow, and orange shades. They bloom most profusely during spring, summer, and fall. Pkt. 15 $\varnothing ; 1 / 8$ oz. $30 \notin$; $1 / 4$ oz. $50 \varnothing ; 1 / 2$ oz. $85 \varnothing$.

Lupines These are truly ing the second season after sowing. They thrive in any ordinary garden soil and make a wonderful display.

3844 White Beautiful pure white flower-spikes; much used as cutflowers. Free blooming, lasting lowe after cutting. Pkt. 10 $1 / 4$ oz. $25 \notin ; 1 / 2$ oz. $40 \notin ;$ oz. $70 \phi$.

3844a Rose A fine rich shade of rose. An excellent cut-flower with long strong flower-spikes. Pkt. $10 \varnothing$; $1 / 4$ oz. $25 \notin ; 1 / 2$ oz. $40 \notin ;$ oz. $70 \notin$.

3845 Blue Bright blue flowers borne freely during June. A most popular variety. Pkt. 10 $\notin ; 1 / 40 z .25 \phi$; $1 / 2$ oz. $40 \notin ;$ oz. $70 \phi$.

3846 Moerheimi Rose and white flowers on long spikes. Pkt. $15 \notin$; $1 / 4$ oz. 35 ; 1/2 oz. 55 $\phi$; oz. $95 \phi$.

Lychnis ( $B u r n i n g$ Star) Corymbs of small, intensely bright scarlet flowers during June and July; 2 feet tall. Pkt. $10 \notin ; 1 / 8$ oz. $25 \notin ; 1 / 4$ oz. $35 \phi$.

3846a Viscaria Splendens (Maltese Cross; Ragged Robin) A fine borde plant with deep red flowers. Blooms during June and July; 2 feet tall. Lupines Pkt. $10 \notin ; 1 / 8$ oz. $25 \notin ; 1 / 4$ oz. $35 \phi$.

Lythrum 3838 Roseum Superbum (Loose-strife) Fine long heads of rich purplish red flowers from early July until late September; 2 to 4 feet tall. Pkt. $15 \not \subset ; 1 / 16$ oz. $50 \not \subset ; 1 / 8$ oz. $85 \not \subset ; 1 / 4$ oz. $\$ 1.45$.

Pentstemon 3854 Giant Floraale Contain $11 / 2$ inches in diameter, and the spikes grow 18 inches long. They are thickly set with flowers. Blooms freely and continuously. Pkt. $15 \not$ $1 / 16$ oz. $35 \not<; 1 / 8$ oz. $55 \not ; 1 / 4$ oz. $95 \not ; 1 / 2$ oz. $\$ 1.65$

Perennial Baby's Breath 3807 Single (Gypsophila paniculata) The tiny white flowers are borne on slender stems. The plants bloom very profusely during June and July. Pkt. $10 \not ; 1 / 4$ oz. $30 \not ; 1 / 2$ oz. 50 .

3799 Double Baby's Breath The small double white flowers are borne most profusely. This is a decided improvement on the single variety because of its great showiness. Attractive in the garden; extremely valuable for cutting. Pkt. 25 $\not$; $1 / 16$ oz. $60 \phi ; 1 / 8$ oz. $\$ 1.00$.

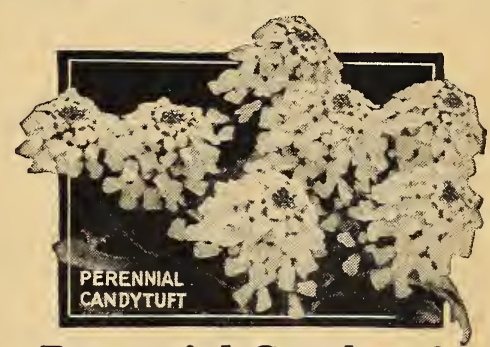

Perennial Candytuft

3829 (Iberis sempervirens) This is a favorite perennial, bearing handsome trusses of pure white flowers. The plants are of dwarf growth, not more than 12 inches tall, and are wonderfully adapted for edging or rockwork. They bloom freely and make a solid bed of white flowers during late April, May, and June. Pkt. 20 $\not$; 1/8 0z. 60 $\not ; 1 / 4$ oz. $\$ 1.00 ; 1 / 2$ oz. $\$ 1.70$

\section{Perennial Flax}

3841 (Linum perenne sibiricum) A rich blueflowered Flax. The attractive flowers last only a day, but they are borne continuously from July on; 15 inches tall. Pkt. $10 \varnothing ; 1 / 4$ oz. $25 \phi$.

\section{Platycodon}

3857 Grandiflorum Mariesii (Chinese Bellflower) The bell-shaped rich blue flowers ar borne profusely during the summer and early fall. It blooms freely and is perfectly hardy; 18 inches tall. Pkt. $15 \notin ; 1 / 16$ oz. $25 \phi ; 1 / 8$ oz. $40 \notin$.

\section{Polyanthus}

3859 Large Flowering, Mixed Charming early spring-flowering plants. Perfectly hardy and most effective for beds or masses. The range of colors includes many fine shades and combinations of white, yellow, rose, red, and violet, also salmon, copper-brown, orange, scarlet, lilac, and mahogany-red. Pkt. 15 $1 / 16$ oz. $45 \notin ; 1 / 8$ oz. $75 \phi ; 1 / 4$ oz. $\$ 1.25 ; 1 / 20 z . \$ 2.15$.

\section{Perennial Garden Collection}

This fine assortment contains one packet each: Anchusa, Carnation, Giant Chabaud Mixed; Delphinium, Choice Mixed; Digitalis, Mixed Hollyhocks, Single Mixed; and Oriental Poppy, Mixed. Value 50 \& 


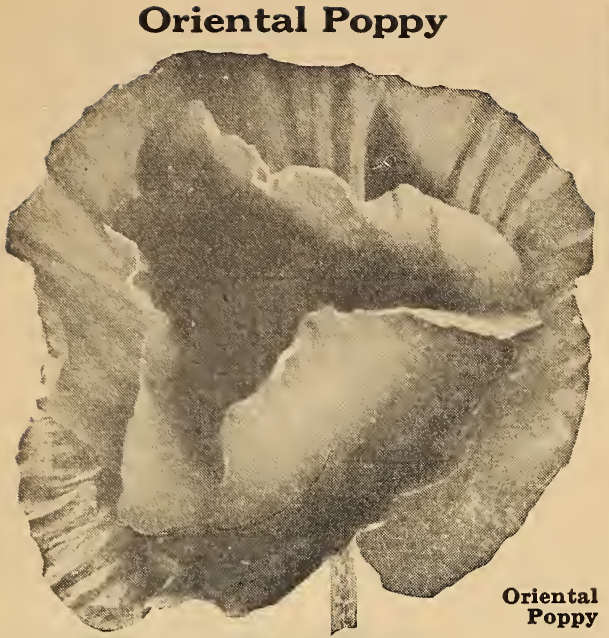

3851 Orientale This is the most showy of all the perennial Poppies. The immense rich scarlet-red flowers are borne profusely during late May and June. Sow the seed where the plants are to bloom, as they do not transplant very satisfactorily. Pkt. $10 \varnothing ; 1 / 8$ oz. 30 $\varnothing ; 1 / 4$ oz. $50 \varnothing ; 1 / 20 z .85 \not$ 3847 Choicest Mixed This fine mixture of Oriental Poppies is composed of a large number of bright shades of scarlet, red, pink, light pink, blush, and white. Immense blooms. Pkt. $10 \phi ; 1 / 8$ oz. $30 \notin ; 1 / 4$ oz. $50 \phi ; 1 / 2$ oz. $85 \phi$.

\section{Plume Poppy 3732 (Bocconia cordata)}

some foliage. Flowers creamy buff, borne in large panicles. Pkt. 10ф; 1/4 oz. 30 ; 1/2 oz. 50 $\varnothing ;$ oz. $85 \phi$.

Primula 3861 Auricula This is a well-known Primula; many bright colors, includin e, copper, brown, and other pastel shades borne in clusters on fine long stems. Excellent for dwarf borders or beds. Pkt. 15 $\varnothing ; 1 / 16$ oz. $50 \notin ; 1 / 8$ oz. $85 \phi$. 3865 Vulgaris (English Primrose) Large, rich yellow flowers; blooms very early. Pkt. $15 \notin ; 1 / 16$ oz.65 $\not ; 1 / 80 z$. $\$ 1.10$.

Pyrethrum 3870 Roseum, Mixed (Insect bearing a profusion of large, Daisy-like flowers in lovely shades of rose, pink, and red, also white. Perfectly hardy, rrowing about 2 feet tall. Blooms during May and June Plkt. $15 \notin ; 1 / 8$ oz. $40 \notin ; 1 / 4$ oz. $65 \notin ; 1 / 20 z$. \$1.10.

3868 Golden Feather (Parthenium aureum) This variety of Pyrethrum has rich yellow foliage. The bushes grow about 6 inches tall. The flowers are small and of a pure white color. Fine for borders. Pkt. 10 $\not 11 / 8$ oz. 35 $\not ; 1 / 4$ oz. $55 \phi$.

Rudbeckia 3873 Purpurea A handsome variety, with large, rosy purple flower borne from July till October. The center of the blooms is purplish black. Pkt. 15 $\notin ; 1 / 8$ oz. 50 $\notin ; 1 / 4$ oz. $85 \notin$.

3874 SPECIOSA (Cone Flower) An easily grown perennial of sturdy habit, thriving in almost any kind of soil. They grow most luxuriantly in a loam soil where there is never a lack of moisture. The petals of the flowers are a rich brilliant yellow and the center is deep purplish brown. Blooms from midsummer until fall. Pkt. 15 ; $1 / 8$ oz. $50 \phi$. Saponaria 3875 Ocymoides (Rock Soapwort) ing from June until late in September. Of creeping habit and excellent for borders or dwarf beds; 6 inches tall. Pkt. $10 \notin ; 1 / 8$ oz. $25 \notin ; 1 / 4$ oz. $35 \phi ; 1 / 2$ oz. $55 \phi ;$ oz. $95 \notin$

Scabiosa 3876 Caucasica (Pincushion Flower) once being established, they will last for many years; 2 feet

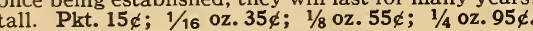

\section{Shasta Daisy 3770 (Maximum) Immense} (n) greateven 2 to 3 feet tall. Pkt. 10 $\varnothing ; 1 / 8$ oz. 30 $\varnothing ; 1 / 4$ oz. 50 $\varnothing ; 1 / 2$ oz. $85 \phi$. ing creeping plant, with silvery foliage and white, starshaped flowers during June. When in full bloom they appear like a bed of snow. Pkt. 15 $;$; 1/8 oz. 35 : 1/4 0z. $55 \varnothing$.

\section{Shell Flower 3764 (Chelone Barbata). Lon} rich coral-red blooms. Blooms most freely in a sunny or semi-shaded location. Flowers from June until September 18 inches tall. Pkt. $10 \varnothing ; 1 / 16$ oz. $25 \phi ; 1 / 8$ oz. $40 \phi$.

Statice 3879 Latifolia (Sea Lavender) A lovely, quaint, hardy perennial. Masses of clea mauve flowers; easily dried for winter; 15 inches tall. Pkt. 15 $\varnothing ; 1 / 8$ oz. $40 \varnothing ; 1 / 4$ oz. $65 \phi ; 1 / 2$ oz. $\$ 1.10$.

Stocks 3880 Emperor or Perpetual These fine Stocks Stocks will live outdoors for several years if protected during winter. Our mixture contains a wide range of colors, including white, pink, rose, red, maroon light blue, lilac, purple, and many intermediate shades; 12 to 18 inches tall. Pkt. $20 \notin ; 1 / 8$ oz. $45 \notin ; 1 / 4$ oz. $75 \notin$.

\section{Sun Rose 3801 (Helianthemum mutabile)} useful in the rock-garden. Blooms during May and June in many shades of rose, pink, and also white. Hardy and a free bloomer. Plant in a sunny spot in the garden where the soil is moderately rich and moist. This showy little perennial is well suited for raising in pots or boxes. The flowers are single and semi-double. Pkt. 10 $\not$; $1 / 16$ oz. $25 \phi$.

\section{Sweet Rocket $\mathbf{3 8 7 2}$ Mired (Hesperis ma-} for three or even four years. The plants grow 2 feet tal and are surmounted by large panicles of white and purple flowers. Pkt. $10 \phi ; 1 / 4$ oz. $25 \phi ; 1 / 2$ oz. $40 \phi ;$ oz. $70 \phi$.

\section{Sweet William $\begin{aligned} & \text { These are excellent for } \\ & \text { border plants and should }\end{aligned}$} be included in every garden. They are grown from seed sown right in the open about the middle of April, but they can be sown during late summer and early fall.

3886 Pink Beauty Beautiful salmon-pink. Very double and free-blooming. Pkt. 15 $\notin ; 1 / 8$ oz. 35 $\not ; 1 / 4$ oz. 55 $\not$.

3890 Scarlet Beauty Attractive rich scarlet flowers. Fine double flowers borne with the greatest freedom during spring and summer. Pkt. 15 $;$; 1/8 0z. 35 $\not ; 1 / 4$ oz. $55 \notin ; 1 / 2$ oz. $95 \notin$. 3892 Double, Mixed Fine double flowers in a great variety of colors. Pkt. 10 $\not ; 1 / 80 z .25 \not ; 1 / 40 z .35 \phi$.

3884 Perfection Single, Mixed A splendid strain of all colors in mixture. Pkt. 10 $\varnothing ; 1 / 8$ oz. $25 \phi ; 1 / 4$ oz. $35 \phi$.

Tunica 3889 Saxifraga This lovely hardy perennial IUnica grows about one foot tall and blooms profusely from June till September. An excellent hardy perennial for the rock-garden. The plants make a spreading growth and form thick tufts which are covered with small delicate rose blooms. Pkt. $10 \notin ; 1 / 8$ oz. $25 \notin ; 1 / 4$ oz. $35 \notin$.

Valerian 3898 Coccinea (Centranthus) Bright alerian red flowers during June and July 3 feet tall. Pkt. $10 \notin ; 1 / 8$ oz. $25 \notin ; 1 / 4$ oz. 35 $\notin ; 1 / 2$ oz. $55 \phi$.

3899 White A white-flowered variety, 3 feet tall. Blooms freely. Pkt. $10 \notin ; 1 / 8$ oz. $25 \phi ; 1 / 4$ oz. 35 $\phi ; 1 / 20 z .55 \phi$.

Veronica 3893a Spicata Mixed (Speedwell) Bright blue, pink, and white flowerspikes during August. Excellent for cutting; 18 inches tall. Pkt. $10 \notin ; 1 / 16$ 0z. $25 \notin ; 1 / 8$ oz. $40 \notin ; 1 / 4$ oz. $65 \notin ; 1 / 2$ oz. $\$ 1.10$.

\section{Violas or Tufted Pansies}

3896 Finest Mixed (Viola cornuta) A grand mixture of all colors. These should be grown more widely as they are very showy, with their graceful violet-like flowers borne with the greatest profusion. Pkt. 10 $\%$; 16 oz. $30 \notin$; $1 / 8$ oz. $50 \phi ; 1 / 4$ oz. $85 \phi$.

Wallfower The sweet-scented flowers are Wallfower most beautiful for beds, borders, and also for cutting. Raised in pots they will bloom freely and can be taken into the house when fall frosts are expected. 3894 Fine Double, Mixed The spikes are closely set with double flowers of many shades, including chocolate-brown, orange, purple, crimson, bright red, etc. Pkt. 15 $\not ; 1 / 16 \mathrm{oz}$. $45 \notin ; 1 / 8$ oz. $75 \notin ; 1 / 4$ oz. $\$ 1.25 ; 1 / 2$ oz. $\$ 2.15$.

3897 Extra-Early Parisian Single golden yellow flowers during spring. A most showy and free-blooming variety; 15 inches tall. Pkt. $10 \notin ; 1 / 16$ oz. $25 \phi ; 1 / 8$ oz. $40 \notin$. 


\section{ASPARAGUS ROOTS}

In nearly all sections south of Philadelphia Asparagus Roots have proven to do particularly well if they are planted in the fall just before cold weather sets in. Since the introduction of the Washington varieties, all the older varieties have become more or less obsolete, at least for the home gardener, and for this reason we are offering the variety Mary Washington, which we consider the best of all.

We are often asked whether to plant one or two-year-old plants. There seems to be no question that for permanent results the oneyear-old roots are preferable. They are much easier to plant and get accustomed more quickly to their new location. They will, however, require a little longer before they can be cut heavily. For quick results the two-year-old roots are recommended. If planted in the fall, they can be cut in a limited way during the second spring.

\section{Mary Washington}

\section{A Most Remarkable almost Rust-Proof Asparagus}

This Asparagus originated with the Department of Agriculture in Washington, D. C., and has been carefully selected so that it will come absolutely true. The most outstanding feature about Mary Washington Asparagus is its resistance to rust. Those who have had trouble with older varieties on account of rust can appreciate what this feature alone means. Mary Washington Asparagus always brings the highest market prices because of its exceptionally large size and good appearance. Home gardeners will find that it is easily grown and outyields all other older varieties. The plants form large clean shoots which are extremely thick and heavy. They are long and straight, with closely folded tips. The color of the stalks when grown under ordinary garden culture is a rich dark green and the tips are a still deeper color of green. When grown by the blanching method they are a fine creamy white color.

Mary Washington Asparagus is a tremendous yielder and a longlived producer of exceptionally fine flavor. The original mother plant, which is now over sixteen years old, is still growing in the trial grounds of the Department of Agriculture in Washington. This is ample proof that the variety is exceptionally long lived. When first introduced some Asparagus specialists were in doubt whether such a succulent strain could withstand yearly severe cutting. There exists no doubt about this after growers everywhere have given it some most severe tests.

Plant your Asparagus in a well-drained soil having a southern exposure. Set the roots 12 inches apart in rows with 4 feet between the rows. 10,000 plants are required to set one acre.

\section{One-year-old-roots Mary Washington Asparagus} 50 for $\$ 1.30$; 100 for $\$ 2.30$, postpaid. By express, purchaser paying transportation charges: 1000 roots $\$ 13.00 ; 5000$ for $\$ 60.00$.

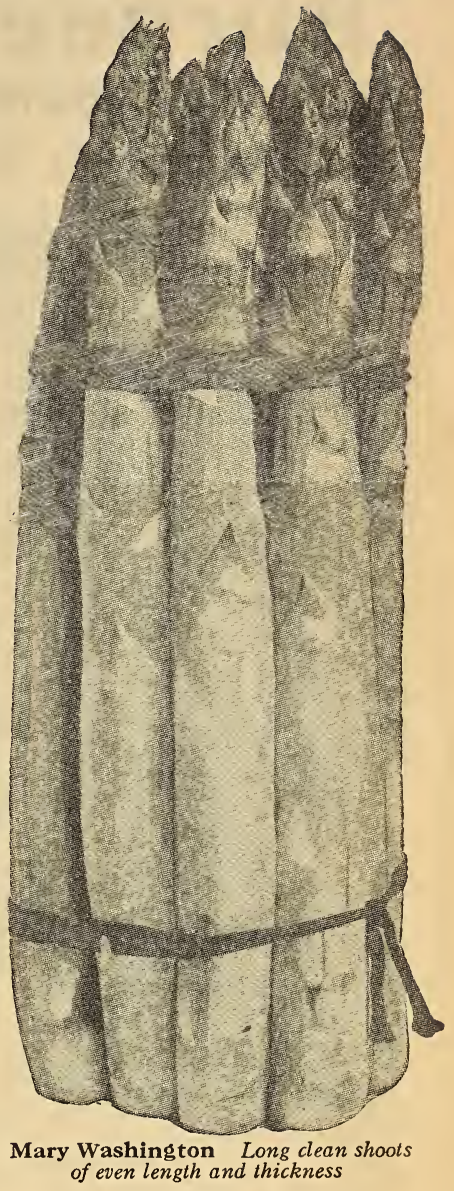

9913 Two-year-old-roots

\section{Seed of Mary Washington Asparagus}

We are offering an outstanding and perfectly true to type strain of seed which can be depended upon to produce uniform plants, embodying all the fine characteristics of this wonderful variety. Pkt. $10 \phi ;$ oz. $25 \phi ; 4$ ozs. $75 \phi$; $1 / 2$ lb. $\$ 1.15 ;$ lb. $\$ 2.00$, postpaid.

\section{ONION SETS 9935 Egyptian, or Perennial Tree} This is a valuable variety because the bulbs are perfectly hardy and can therefore be planted during the fall. They may be left in the ground year after year without injury. The coppery red bulbs are quite flat and produce excellent scullions for early spring use. If left growing they will make a medium size bulb that can be harvested at the end of the season. These sets will be ready for delivery in September and should be planted upon receipt. Lb. 35 ; $2 \mathrm{lbs} .65 \phi ; 5 \mathrm{lbs}$. $\$ 1.40$, postpaid. By express or freight, $100 \mathrm{lbs}$. $\$ 20.00$.

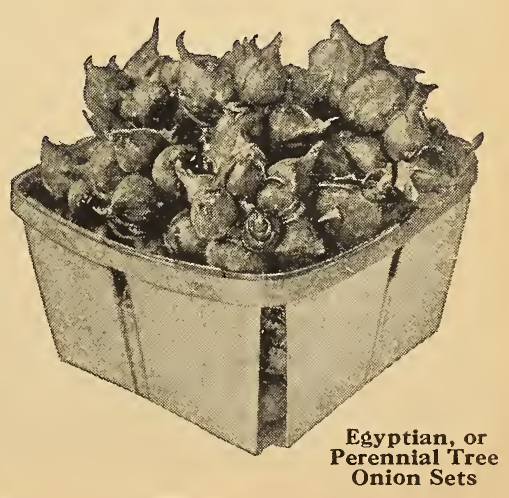




\section{Burpee's Lawn Grass FOR SUMMER and FALL SOWING}

\section{Burpee's Fordhook Finest Lawn Grass}

We believe that our Fordhook Finest Lawn Grass is unequaled in every respect. CarefuI experiments have proven that best results with the lawn depend upon theuse of the proper mixture of the right kind of grasses with high germination.

Fordhook Finest contains a well-balanced blend of various American and foreign finebladed and deep-rooting varieties which have given best results under the varied conditions of soils and climate met with in America. Fordhook Finest will make a smooth, green, velvety sod with a thick bottom. It is free from common grasses which produce clumps and knots in the lawn, greatly spoiling the desired smooth deep effect.

Fordhook Finest Lawn Grass contains no chaff and weighs 25 to 27 pounds per measured
bushel. A small quan-

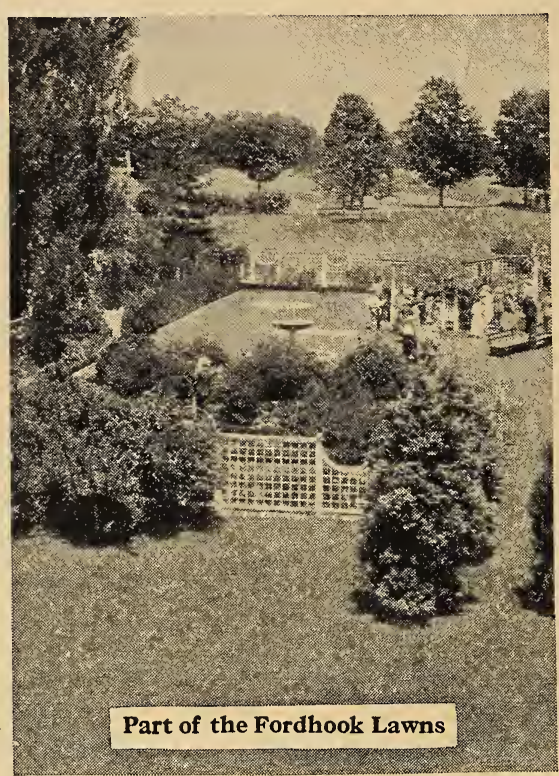

tity of white clover is included in Fordhook Finest Lawn Grass, but only sufficient to help thicken the bottom of the sod. Those who prefer much clover could add White Dutch Clover, offered below, at the rate of 4 ozs. for each 5 Ibs. of grass seed.

One pound of seed is sufficient to sow a plot $15 \times 20$, or 300 square feet. One hundred pounds per acre are sufficient for careful seeding, but it is better to use 150 pounds per acre where it is desired to have a good close turf from the start.

Ask for a free copy of the Burpee leaflet, "How to Establish a Lawn." Lb. 60 \&; 2 lbs. $\$ 1.10 ; 5$ lbs. $\$ 2.50$; $10 \mathrm{lbs}$. \$4.75, postpaid. By express or freight, 25 lbs. \$9.75; 50 lbs. $\$ 18.50$; 100 lbs. $\$ 35.00$; 250 lb . $\$ 85.00$; 500 lbs. $\$ 165.00$.

\section{Golf Links}

This mixture is composed exclusively of fine-bladed grasses which will withstand frequent close cutting and trampling. It is free from weedseed and contains no white clover, the latter not being suitable for the closely cut golf lawn.

We have made a special study of this subject to make Burpee's Golf Link Mixture the standard. Sow 150 Ibs. per acre. Lb. 60 $\dot{0}$; 2 lbs. $\$ 1.10$; 5 lbs. $\$ 2.50 ; 10$ lbs. $\$ 4.75$, postpaid. By express or freight, purchaser paying for transportation, 25 lbs. \$9.75; 50 lbs. \$18.50; 100 lbs. $\$ 35.00 ; 250$ lbs. $\$ 85.00 ; 500$ lbs. $\$ 165.00$.

\section{Putting Greens A mixture of} eties of Bent grasses with a preponderance of Creeping Bent. These grasses are the most satisfactory for putting greens, as they make a smooth even growth which will withstand frequent close cutting and intense trampling. The seed we offer is of the highest quality. Lb. \$1.15; 2 lbs. $\$ 2.20$; 5 lbs. $\$ 5.25 ; 10$ lbs. $\$ 10.25$, postpaid. By express or freight, at purchaser's expense, 25 lbs. $\$ 25.00 ; 50$ lbs. $\$ 45.00 ; 100$ lbs. $\$ 85.00$.

\section{Sunny South Lawn We} prepared a special mixture that is particularly suited for the hot, dry sections of the South. With care and regular watering, Sunny South Mixture will produce satisfactory lawns under the most exacting conditions of weather and soil. Lb. 50 \&; 2 lbs. 95 \&; 5 lbs. $\$ 2.35 ; 10$ lbs. $\$ 4.25$, postpaid. By express or freight, purchaser paying for transportation, 25 lbs. $\$ 9.00 ; 50$ lbs. $\$ 17.50$; 100 lbs. $\$ 34.00 ; 250$ lbs. $\$ 83.00 ; 500$ lbs. $\$ 160.00$.
6149 Shady Nook We have prepared is composed entirely of choice, clean seed of the finest and most costly grasses adapted for semishaded locations. It will make a fine lawn where trees or large buildings prevent the ordinary mixtures from growing satisfactorily.

Sow 150 lbs. per acre. Lb. 60c; 2 lbs. \$1.10; 5 lbs. $\$ 2.50$; 10 lbs. $\$ 4.75$, postpaid. By express or freight, purchaser paying for transportation, 25 lbs. $\$ 9.75 ; 50$ lbs. $\$ 18.50 ; 100$ lbs. $\$ 35.00$; 250 lbs. $\$ 85.00 ; 500$ lbs. $\$ 165.00$.

6144 Tererace Sod. The terrace is ofttimes a source of a great deal of worry and trouble. This is largely due to the fact that the right grasses are not used in the making of the terrace sod. We have prepared a Special Mixture containing only those grasses that are best adapted to embankments and terraces. These grasses are all deep-rooted. Sow 150 to $175 \mathrm{lbs}$. per acre. Lb. 60\&; $2 \mathrm{lbs}$. $\$ 1.10 ; 5$ lbs. $\$ 2.50 ; 10$ lbs. $\$ 4.75$, postpaid. By express or freight, purchaser paying for transportation, 25 lbs. $\$ 9.75 ; 50$ lbs. $\$ 18.50$; 100 lbs. $\$ 35.00 ; 250$ lbs. $\$ 85.00 ; 500$ lbs. $\$ 165.00$.

\section{White Dutch Clover While}

mixtures, except Golf Links, Putting Greens, and Sunny South, contain a small quantity of White Dutch Clover, many gardeners like to sow an additional quantity of it. Use at the rate of one pound of Clover for 20 pounds of grass seed. Pkt. (4 ozs.) 30 $\notin ; 1$ b. 80 ; 2 lbs. $\$ 1.55 ; 5$ lbs. $\$ 3.75$; 10 lbs. \$7.00, postpaid. By express or freight, at purchaser's expense, 100 lbs. $\$ 60.00$. 

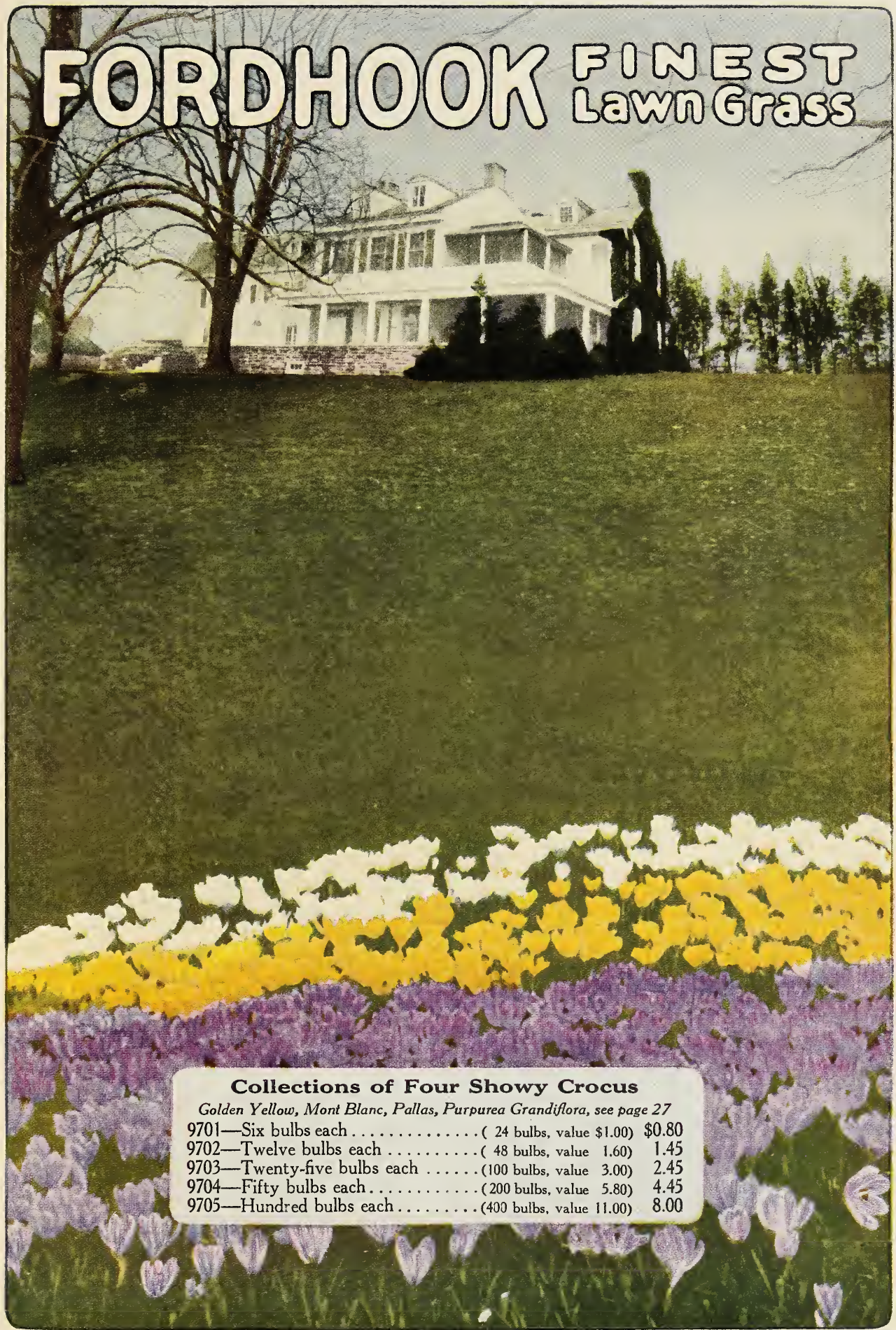

Copyright, 1927, by W. Atlee Burpee Co., Philadelphia, Pa. U. S. A. 


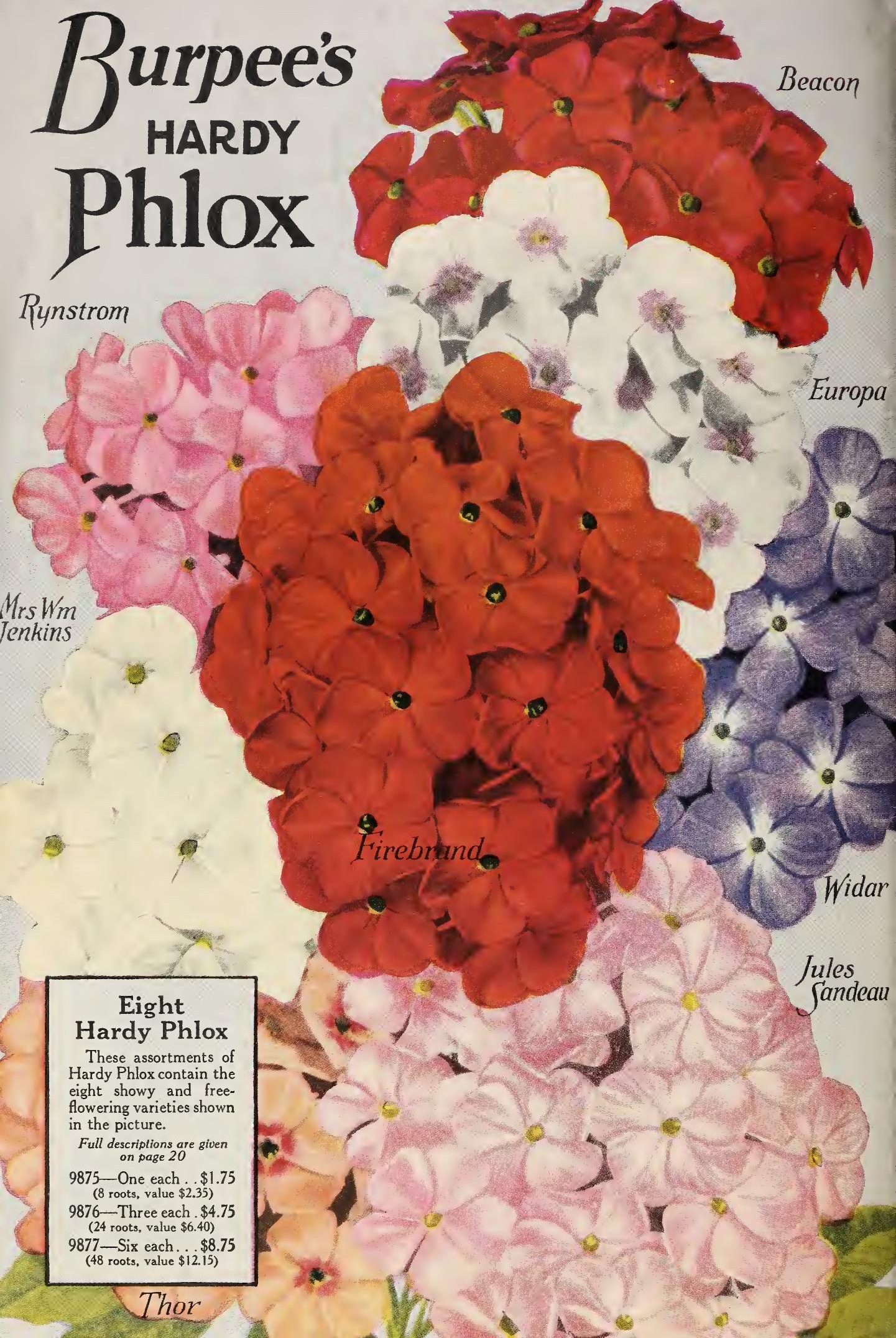

